ANA LUIZA BOULOS RIBEIRO

O NASCITURO COMO PESSOA E OS REFLEXOS NO SISTEMA DA RESPONSABILIDADE CIVIL 
ANA LUIZA BOULOS RIBEIRO

\section{O NASCITURO COMO PESSOA E OS REFLEXOS NO SISTEMA DA RESPONSABILIDADE CIVIL}

Dissertação apresentada à Faculdade de Direito da Universidade de São Paulo para obtenção do título de Mestre em Direito.

Área de Concentração: Direito Civil

Orientadora: Professora Dra. Titular Silmara Juny de Abreu Chinellato

SÃO PAULO

2010 


\section{O NASCITURO COMO PESSOA E OS REFLEXOS NO SISTEMA DA RESPONSABILIDADE CIVIL}

Dissertação apresentada à Faculdade de Direito da Universidade de São Paulo para obtenção do título de Mestre em Direito.

Área de Concentração: Direito Civil

Orientadora: Professora Dra. Titular Silmara Juny de Abreu Chinellato

Aprovada em:

BANCA EXAMINADORA

Prof.

Instituição:

Julgamento:

Assinatura:

Prof.

Instituição:

Julgamento:

Assinatura:

Prof.

Instituição:

Julgamento:

Assinatura: 
Dedico este trabalho aos meus pais, não somente pelo apoio incondicional, mas também por serem quem são e sempre estarem presentes.

À minha mãe, meu grande alicerce, que, acreditando em mim, me ensinou sobre fé, persistência e realização.

Ao meu pai, exemplo de determinação e esforço, que construiu meu mundo com muito amor. 


\section{AGRADECIMENTOS}

Agradeço, primeiramente, a Deus, sem o qual nada seria possível.

Em especial, à Professora Silmara Juny de Abreu Chinellato, pela oportunidade a mim conferida e por seus ensinamentos inspiradores.

Às revisoras Bianca Galafassi e Bruna Bassette, agradeço pelo auxílio prestado com tanto carinho.

Aos meus irmãos, Guilherme e Gustavo, exemplos de ética e bondade, por fazerem parte da minha vida.

E às queridas Camilla, Luana, Kátia e Nathalia, que dividiram minhas incertezas e me acompanharam lado a lado nessa trajetória. 


\section{RESUMO}

O estudo em comento traz mais uma reflexão sobre o tema do nascituro sob uma perspectiva ética e consubstanciada na atual realidade biotecnológica, que proporciona conhecimento amplo sobre todas as fases de desenvolvimento do ser humano. Ainda, amparado em uma visão humanista de respeito à dignidade da pessoa humana, são analisados as principais teorias acerca da natureza jurídica do nascituro e os reflexos para a atual tendência do sistema da responsabilidade civil de ampla reparação e de ampliação dos danos indenizáveis, calcados na doutrina e na jurisprudência nacionais. Assim, buscou-se uma releitura das normas postas sobre o início da personalidade jurídica, sob uma ótica objetiva, delineando o valor positivo existente na sociedade e de modo integrado com todo o ordenamento jurídico. Visou-se, por fim, consagrar a máxime constitucional do princípio da igualdade, que deve ser garantido a todos os seres humanos, sem quaisquer distinções.

Palavras-chave: Biodireito. Nascituro. Início da Personalidade Jurídica. Dano Moral. Responsabilidade Civil. 


\section{RIASSUNTO}

Lo studio commentato rapporta più una riflessione sul tema del nascituro alla luce di una prospettiva etica e consolidata nella realtà biotecnologica attuale, che offre conoscenza in maniera più ampia su tutte le fasi dello sviluppo dell'essere umano. Inoltre, fondate in una visione umanista di rispetto alla dignità della persona umana, sono analizzate le principali teorie sulla natura giuridica del nascituro ed i riflessi della tendenza attuale del sistema della responsabilità civile di ampia riparazione e di ampliamento dei danni indennizzabili, calcolati sia dalla dottrina che dalla giurisprudenza nazionale. In questo modo, si propone una rilettura delle norme stipulate sull'inizio della personalità giuridica, attraverso un'ottica obiettiva, tracciando il valore positivo esistente nella società e di modo integrato con tutte le disposizioni giuridiche. Finalmente, si è giunto al proposito di consacrare la massima costituzionale del principio di uguaglianza, che deve essere garantito a tutti gli esseri umani, senza nessuna distinzione.

Parole chiave: Biodiritto. Nascituro. Inizio della Personalità Giuridica. Danno Morale. Responsabilità Civile. 


\section{SUMÁRIO}

INTRODUÇÃO.

\section{Capítulo 1 \\ NOTÍCIA HISTÓRICA}

$1 \quad$ Notícia Histórica..

13

\section{Capítulo 2 \\ DISTINÇÕES CONCEITUAIS}

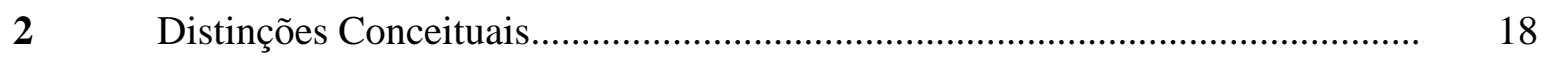

2.1 Conceito de Nascituro e de Prole Eventual...................................................... 18

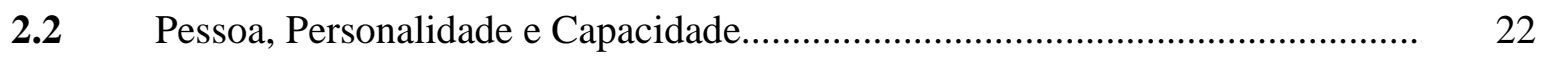

2.3 Início da Vida e Início da Personalidade Jurídica................................................. 29

\section{Capítulo 3}

INÍCIO DA PERSONALIDADE JURÍDICA:

PRINCIPAIS ESCOLAS DOUTRINÁRIAS

$3 \quad$ Início da Personalidade Jurídica: Principais Escolas Doutrinárias

\section{Capítulo 4 \\ O NASCITURO NO DIREITO ESTRANGEIRO}

$4 \quad$ O Nascituro no Direito Estrangeiro................................................................. 40

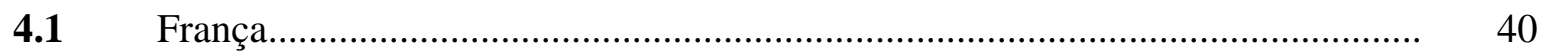




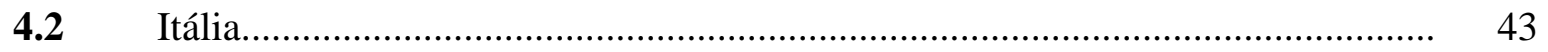

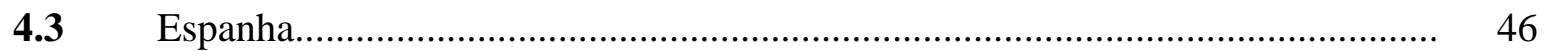

$4.4 \quad$ Portugal..................................................................................... 48

$4.5 \quad$ Argentina......................................................................................... 50

\section{Capítulo 5}

\section{O NASCITURO PERANTE O ORDENAMENTO JURÍDICO BRASILEIRO}

$5 \quad$ O nascituro perante o ordenamento jurídico brasileiro........................................... 51

5.1 Constituição da República Federativa do Brasil de 1988....................................... 51

5.2 Tratados e Convenções Internacionais.................................................................. 56

5.2.1 Pacto de São José da Costa Rica........................................................................ 60

5.2.2 Convenção Internacional sobre os Direitos da Criança............................................ 60

5.2.3 Pacto Internacional de Direitos Civis e Políticos das Nações Unidas.................... 62

5.2.4 Recomendações do Conselho da Europa........................................................... 61

$5.3 \quad$ Código Civil de 2002.................................................................................... 62

5.3.1 Aspectos anteriores ao Código Civil de 2002 ...................................................... 62

5.3.2 O artigo $2^{\circ}$ do Código Civil de 2002................................................................. 64

5.3.3 Demais referências ao nascituro no Código Civil de 2002..................................... 65

$5.4 \quad$ Legislação Civil Extravagante............................................................................. 66

\section{Capítulo 6 \\ O NASCITURO COMO PESSOA}

$6 \quad$ O Nascituro como Pessoa................................................................................ 68

6.1 O Nascituro como Sujeito de Direitos................................................................ 68

6.2 Direitos da Personalidade e o Nascituro.................................................................. 72 


\section{Capítulo 7 \\ RESPONSABILIDADE CIVIL POR DANO \\ CAUSADO AO NASCITURO}

$7 \quad$ Responsabilidade Civil por Dano Causado ao Nascituro..................................... 76

7.1 A Evolução do Instituto da Responsabilidade Civil........................................... 76

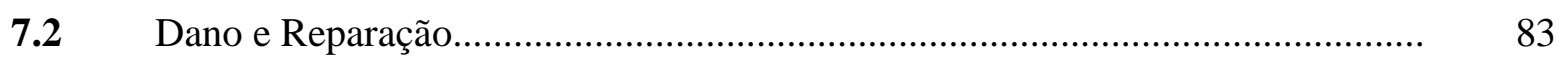

7.3 A Personalidade Civil do Nascituro como Fundamento para a Reparação... $\quad 87$

7.4 Dos Danos Causados ao Nascituro.................................................................... 91

7.4.1 Dano Moral Causado ao Nascituro.......................................................................... 94

7.4.2 Dano Patrimonial Causado ao Nascituro................................................................ 109

7.4.3 Dano Causado aos Pais: Morte do Nascituro e Wrongful Birth.......................... 111

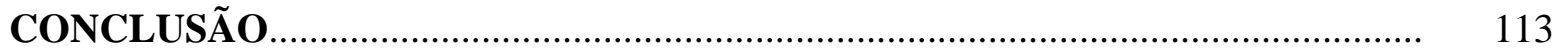

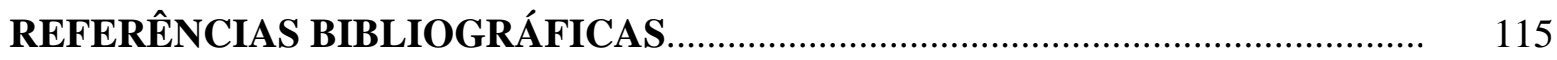




\section{INTRODUÇÃO}

Temas relacionados à Bioética nunca estiveram tão em voga nos debates jurídicos como nos dias de hoje. Prova disso são as fervorosas discussões sobre questões bioéticas travadas no meio acadêmico, na prática forense diária e, inclusive, nos tribunais superiores. O termo "bioética”, ou "ética da vida”, surgiu no início da década de 70 como um neologismo, e foi usado pela primeira vez pelo oncologista norte-americano Van Rensselaer Potter (1911 - 2001), nos anos de 1970-71, em um artigo intitulado "Bioethics, science of survival” e em seu livro "Bioethics bridge to the future". Essa ciência recente primou por estudos científicos quanto aos problemas morais encontrados do início ao fim da vida. ${ }^{1}$

A Bioética ganhou evidência principalmente depois do grande desrespeito ao ser humano vivenciado na Segunda Guerra Mundial. Desde então, tornou-se necessária e tem sido colocada em pauta por diversos profissionais - como filósofos, sociólogos, juristas -, tornando-se multidisciplinar e enfrentando, hoje, todos os dilemas éticos referentes à vida humana. Talvez não por outro motivo já se fale em um novo ramo do Direito, o chamado Biodireito.

A Bioética se relaciona ao Direito em todos os aspectos, uma vez que nos traz uma importante reflexão sobre valores. Apesar de ser um campo de estudo novo, apenas com quatro décadas de existência, revela-se uma ferramenta essencial da sociedade para a proteção do ser humano frente aos avanços inconsequentes e desmedidos da biotecnologia. E para o Direito representa importante fonte para a solução de diversos conflitos surgidos nessa nova era, não por trazer respostas para os problemas apresentados, mas por nos obrigar a refletir criticamente, de forma a delinear um caminho de respeito à dignidade do ser humano, no qual a própria sociedade estabelece os contornos e limites de seus passos.

Encontramo-nos na seara da - assim chamada por Norberto Bobbio - " 4 a era dos direitos”, 2 voltada à proteção da vida humana frente ao descomedido avanço científico, em especial o avanço proporcionado pela engenharia genética.

\footnotetext{
${ }^{1}$ A Enciclopédia de Bioética traz, atualmente, o seguinte conceito: “Bioética é um neologismo derivado das palavras gregas bios (vida) e ethike (ética). Pode-se defini-la como o estudo sistemático das dimensões morais - incluindo visão, decisão, conduta e normas morais - das ciências da vida e do cuidado da saúde, utilizando uma variedade de metodologias éticas num contexto interdisciplinar”.

${ }^{2}$ BOBBIO, Norberto. A Era dos Direitos. Rio de Janeiro: Elsevier, 2004. Apenas a título de observação, embora Norberto Bobbio se refira à quarta dimensão dos direitos humanos contemplando a evolução dos avanços no campo
} 
Embora muitos se declarem contra os avanços científicos, vivenciamos uma dubiedade, pois a mesma ciência que destrói é também a ciência que informa e protege. É certo que o avanço da ciência biotecnológica traz a preocupação quanto aos seus limites, mas também é ela que proporciona conhecimento suficiente sobre o ser humano, de modo a trazer bem-estar e segurança. É nessa “ponte”, como queria Potter, entre o desenvolvimento e a ética da vida, que se encontra o Direito, como ramo cientifico único capaz de regular as situações adversas da modernidade.

Nesse sentido, justifica-se o tema escolhido - “o nascituro como pessoa e os reflexos no sistema da responsabilidade civil” - visando à nova reflexão sobre o tema do início da vida na seara jurídica e sobre as consequências de se manter um posicionamento tradicional quanto ao início da personalidade jurídica, frente ao princípio universal de proteção do ser humano.

Hoje, tem-se conhecimento de todas as fases do desenvolvimento humano, sendo inegável o surgimento de um ser diferenciado a partir da fecundação. No entanto, ainda há quem se oponha à proteção jurídica do nascituro, bem como à proteção de seus direitos. A cisão doutrinária se dá tendo em vista uma legislação civil confusa e aparentemente contraditória.

Nesse sentido, este trabalho tem por objetivo demonstrar que o pensamento jurídico atual caminha para o respeito ao ser humano desde os primórdios de seu desenvolvimento, o que se fará demonstrando-se as consequências para o sistema da responsabilidade civil em não reconhecer a personalidade jurídica do nascituro, destacando-se de que formas e em que casos o nascituro poderia ser indenizado, com fundamento na doutrina e na jurisprudência atual e conduzindo-se a uma releitura do Direito posto, face à nova realidade social e doutrinária.

Para tanto, utilizaremos como metodologia a análise da Doutrina nacional e estrangeira, bem como a análise do tratamento jurisprudencial dado ao nascituro pelos principais tribunais brasileiros. Traçaremos, num primeiro momento, um panorama geral sobre as principais teorias quanto à natureza jurídica do nascituro, seu tratamento no ordenamento jurídico e seus direitos. Num segundo momento, com base na jurisprudência existente e no pensamento doutrinário acerca dos problemas jurídicos envolvendo a tutela civil do nascituro, discutiremos os possíveis

da engenharia genética, por colocarem em risco a própria existência humana, Paulo Bonavides, no seu Curso de Direito Constitucional, em contrapartida, refere-se à mesma dimensão tendo em vista a globalização política e a institucionalização do Estado social. Diz serem direitos de $4^{\mathrm{a}}$ geração os direitos à democracia, à informação e ao pluralismo. Neste trabalho, adotamos a classificação de Norberto Bobbio. 
danos de serem causados ao mesmo, bem como a possibilidade de reparação civil a ser humano ainda em fase ainda inicial de desenvolvimento.

Temos a relevância prática desse trabalho consubstanciada na busca de concretização do valor maior da dignidade da pessoa humana, face à tutela que todo ser humano assim considerado, de forma igualitária, recebe do ordenamento jurídico. Seguimos, ademais, uma das novas tendências do instituto da Responsabilidade Civil - a de expansão dos danos suscetíveis de reparação, garantindo que nenhuma lesão fique sem seu devido ressarcimento. Este trabalho consagra, por fim, o princípio universal de que a todos os seres humanos deve ser dispensado tratamento igualitário, sendo respeitada sua dignidade e valorizadas suas potencialidades. 


\section{NOTÍCIA HISTÓRICA}

Traçar um panorama histórico do tratamento conferido ao nascituro pelo Direito brasileiro seria impossível sem antes contextualizar o instituto no Direito romano. A importância do Direito romano se justifica pela grande influência deste no nosso ordenamento jurídico atual. Por este motivo, abrimos aqui um espaço para este feito, mesmo que de maneira breve.

Num primeiro momento, cabe lembrar o que os romanos entendiam por pessoa. No Direito romano, para ser pessoa e adquirir personalidade, devia-se preencher certos requisitos: o nascimento perfeito (com vida, viabilidade e forma humana) e a capacidade. ${ }^{3}$ Nesse sentido, Silvio de Salvo Venosa, ao aduzir os primordiais entendimentos acerca de pessoa e personalidade, relembra que em Roma e em todas as civilizações antigas a personalidade não era um atributo de todas as pessoas (entendidas como seres humanos), mas sim um privilégio, para o qual concorriam determinadas condições. ${ }^{4}$

Conforme Cretella Júnior, em Roma era preciso preencher duas condições para ser pessoa e, portanto, ter personalidade completa: uma natural, consistente no nascimento perfeito (nascimento com vida, forma humana e viabilidade fetal), e uma civil, consistente na presença de um status (uma qualidade, condição civil de capacidade) criado pela doutrina romana. ${ }^{5}$

O conceito de personalidade jurídica no Direito romano diferia do de pessoa. Para adquirir personalidade jurídica, não bastava o nascimento com vida; era preciso que o feto estivesse completamente separado do ventre materno, fosse viável e tivesse forma humana. ${ }^{6}$ Mas, a bem da verdade, isso não era suficiente para a aquisição da plena personalidade jurídica, pois, como dito, o reconhecimento da pessoa física era diferente do de personalidade, sendo necessária a concorrência de três estados: status civitatis; status familiae; status libertatis. ${ }^{7}$ Quanto a este

\footnotetext{
${ }^{3}$ CRETELLA JÚNIOR, José. Curso de Direito Romano: o direito romano e o direito civil brasileiro. 24. ed. Rio de Janeiro: Forense, 2000. p. 62.

${ }^{4}$ VENOSA, Silvio de Salvo. Direito Civil. v. 1 - Parte Geral. 6. ed. São Paulo: Atlas, 2006. p. 114.

${ }^{5}$ CRETELLA JÚNIOR, José. Op. cit., p. 61.

${ }^{6}$ PORCHAT, Reinaldo. Da pessoa physica em Direito Romano: sua condição natural, o nascimento perfeito; sua condição civil, o status. Revista da Faculdade de Direito de São Paulo, Typ. Siqueira Nagel \& Cia, 1913, ano de 1911, vol. 19, p. 9-33.

${ }^{7}$ Conforme nos ensina Cretella Júnior, havia três status: o status civitatis, o status libertatis e o status familiae. Apenas reunidos estes três status haveria a capacidade plena de direito. Em razão da idade, do sexo ou da mente, a capacidade de fato poderia ser limitada. No caso dos escravos, cabe ressaltar que não eram considerados pessoa, não
} 
último, tínhamos a divisão dos cidadãos romanos em livres ou escravos, sendo que os escravos eram privados não somente da liberdade, mas também de qualquer traço de personalidade. A condição de escravo, portanto, era análoga a de coisa ou animal, sendo-lhes negada a personalidade. $^{8}$

Em consulta a romanistas, verifica-se que o sistema romano não atribuiu paridade jurídica a todos os seres humanos, mas apenas atribuiu qualidade de pessoa àqueles que preenchiam determinadas condições, uma vez que concebia o termo pessoa como expressão eminentemente jurídica que não se confunde com o homem, reconhecendo a apenas alguns poucos personalidade jurídica plena. Cretella Júnior, nesse sentido, ressalta que:

não basta, pois, ser homem para ser pessoa. É preciso ser homem, ter forma humana e não estar na condição de escravo. Só assim temos a pessoa, que se erige como centro de direitos e obrigações na ordem jurídica romana.(...) Pessoa e homem são conceitos diversos para o romano. Só o homem que reúne certos requisitos é pessoa. Pessoa é o ser humano acompanhado de atributos. Pessoa é o sujeito de direitos e obrigações. ${ }^{9}$

Ultrapassada essa primeira questão e caminhando ao entendimento do nascituro propriamente dito no Direito romano, percebemos, a partir de uma breve análise dos diferentes manuais de Direito Civil, que a doutrina aponta uma aparente contradição entre as fontes no que concerne ao nascituro, a qual tem gerado conclusões antagônicas dos estudiosos do Direito.

Sobre tal contradição alerta Teixeira de Freitas, dispondo que “o Direito Romano estabelece em vários textos, que, durante a gestação, o filho não é ainda criatura humana” e, em continuidade, que "outros textos, ao contrário, reconhecem a realidade assemelhando o nascituro, ao filho já nascido”. 10

possuindo qualquer capacidade e equivalendo a res. CRETELLA JÚNIOR, José. Curso de Direito Romano: o direito romano e o direito civil brasileiro, p. 62.

${ }^{8}$ Traçando um paralelo entre a falta de personalidade jurídica conferida aos escravos e a falta de personalidade jurídica conferida ao nascituro, eis um interessante comentário de Luciano Dalvi Norbim em nota de rodapé de sua obra $O$ direito do nascituro à personalidade civil: "Vemos que os civilistas ao admitirem a falta de personalidade do nascituro e a descriminalização do aborto acabam por regenerar características de um sistema falido, qual seja, a escravidão. Porém não explicitamente, mas uma escravidão implícita que trata o nascituro como coisa e não como pessoa, não lhe confere direito à herança (só se nascer com vida) e ainda admite sua morte, ou seja, como o escravo o nascituro não tem resguardado o direito à vida. Verdadeiro absurdo!!!”. NORBIM, Luciano Dalvi. O direito do nascituro à personalidade civil. Brasília: Brasília Jurídica, 2006. p. 25-26.

${ }^{9}$ CRETLLA JÚNIOR, José. Op. cit., p. 61.

10 TEIXEIRA DE FREITAS, Augusto. Esboço do Código Civil. Brasília: Ministério da Justiça, Fundação Universidade de Brasília, 1983. p. 84, comentário ao artigo 221. 
Nesse sentido, Clóvis Bevilaqua também aponta tal problema: “o direito romano é vacilante”. E justificando tal afirmativa, continua

\begin{abstract}
Umas vezes nos diz com trecho de Papiniano (D.35, fr. 9, $\S 1^{\circ}$ ): partus nondum editus homo non recte fuisse dictur; e com Ulpiano (D.25,4, fr. $1, \S 1^{\circ}$ ): partum antequam edatur mulieris portio est, vel viscerum. Outras vezes é o mesmo Paulo que declara (D.1,5, fr. 7): qui in utero est perinde ac si in rebus humanis esset custoditur, quotien de commodis ipsius queritur; ou é Juliano que ensina (D.1,5, fr. 26): qui in utero sunt in toto pene jure civili intelliguntur in rerum natura esse. ${ }^{11}$
\end{abstract}

Essa aparente contrariedade das fontes levou a doutrina a sustentar posições opostas com base nos mesmos textos.

Evidenciando tal celeuma, podemos citar de um lado Reinaldo Porchat, que conclui que em Roma o nascituro não era considerado pessoa e não tinha, portanto, direitos. ${ }^{12}$ De outro lado, notamos Pierangelo Catalano, que, com base nas mesmas fontes, demonstra que o princípio geral era de proteção ao nascituro e de reconhecimento de direitos a ele, sendo as fontes ditas contraditórias a esse princípio meras exceções. Ele afirma, inclusive, que

\begin{abstract}
segundo o Direito Romano, ao menos em época justinianéia, o conceito da existência do nascituro está em conexão com o princípio geral de paridade ontológica, com base no qual se devem considerar excepcionais, seguindo também o critério do commodum, as “partes do direito” (ou “causas” ou “questões”) em relação às quais não se aplica dito princípio. ${ }^{13}$
\end{abstract}

Hélcio Maciel, que elaborou aprofundada pesquisa e análise das fontes do Corpus Iuris Civilis, com a revisão das citações em latim e a conferência das fontes romanas, o que culminou na obra $O$ nascituro no Direito Romano, ressalta, entre outras coisas, a importância do cuidado na análise dos manuais existentes: “as teorias existentes e constantes dos manuais podem até estar corretas nas suas conclusões, mas os argumentos apresentados são contraditórios”. ${ }^{14}$

Moreira Alves afirma que para os juristas romanos o feto seria parte das vísceras da mulher, não sendo considerado pessoa. E fundamenta tal afirmação nos brocados: “partus enim antequam edatur, mulieris portio est uel uiscerum" e "partus nondum editus homo non recte

\footnotetext{
${ }^{11}$ BEVILAQUA, Clóvis. Teoria Geral do Direito Civil. Campinas: Servanda, 2007. p. 100.

12 PORCHAT, Reinaldo. Da pessoa physica em Direito Romano: sua condição natural, o nascimento perfeito; sua condição civil, o status, p. 9-33.

${ }^{13}$ CATALANO, Pierangelo. Os nascituros entre o Direito Romano e o direito latino-americano. Trad. Eduardo César Vita Marchi. Revista de Direito Civil, n. 45, ano 12, jul./set. 1998, p. 11.

${ }^{14}$ MACIEL, Hélcio. O nascituro no direito romano: conceito, terminologia e princípios. São Paulo: Companhia Editora Nacional, 2005. p. 102.
} 
fuisse dicitur". ${ }^{15}$ Mas o mesmo autor afirma, adiante, que o Direito romano admitia que fosse o nascituro instituído herdeiro num testamento ou que se nomeasse curador para cuidar de seus interesses, bem como assinala a regra geral estabelecida no Direito justinianeu de que "o nascituro, quando se trata de vantagem a seu favor, se considera como se estivesse vivo (in rerum natura esse)". 16

Thomas Marky, nesse sentido, também aduz não ser o nascituro pessoa, mas ressalva que o Direito romano “considerava o nascituro como já nascido (ficção), para fins de reservar-lhe vantagens", o que fazia com fundamento no preceito "nasciturus pro iam nato habetur, quotiens de commodis ipsius partus agatur” (cf. Gai. 1.147 e D. 1.5.7). ${ }^{17}$

Pasquale Voci, embora afirme que para o Direito romano a existência do homem tinha início com o nascimento, também aponta a regra geral de que o nascituro era considerado como se já fosse nascido quando se tratava de se lhe atribuir uma vantagem. ${ }^{18}$

Caio Mário também aduz que no Direito romano a personalidade jurídica coincidia com o nascimento, sendo o feto uma parte da mãe (“portio mulieris vel viscerum”) e não uma pessoa, não possuindo aquele, portanto, direitos ou atributos reconhecidos ao homem. Complementa seu raciocínio, porém, com a seguinte afirmativa:

\footnotetext{
Mas, isto não obstante, os seus interesses eram resguardados e protegidos, e em atenção a eles, muito embora se reconhecesse que o nascimento era requisito para a aquisição de direitos, enunciava-se a regra da antecipação presumida de seu nascimento. ${ }^{19}$
}

Por outro lado, Teixeira de Freitas, com base nas fontes romanas que previam a curatela ao ventre e nas Ordenações L. $3^{\circ}, \mathrm{T} 18, \S 7^{\circ}$, que traziam a figura da posse dada à mãe em nome do ventre, entendia que, para os romanos, o nascituro era um ser já existente, embora não nascido, pelo simples fato de já existir no ventre materno e que, por isso, necessitava de representação nos casos de doação ou herança. ${ }^{20}$

Nesse sentido, Hélcio Maciel, enfatiza e conclui que é bem verdade que as fontes, por vezes, deixam transparecer as diferenças de convicção
ou a incerteza de opinião sobre o assunto, o que é bastante razoável no contexto histórico
romano. Mas a incerteza no plano biológico não passou para o plano jurídico, no qual o

\footnotetext{
${ }^{15}$ MOREIRA ALVES, José Carlos. Direito Romano. 14. ed. Rio de Janeiro: Forense, 2007. p. 98.

${ }^{16}$ Ibidem, p. 102.

${ }^{17}$ MARKY, Thomas. Curso Elementar de Direito Romano. 8. ed. São Paulo: Saraiva, 1995. p. 28.

${ }^{18}$ VOCI, Pasquale. Manuale di Diritto Romano. t. II. Milano: Giuffrè, 1998. p. 229-230.

${ }^{19}$ PEREIRA, Caio Mário da Silva. Instituições de Direito Civil. v. 1. 19. ed. Rio de Janeiro: Forense, 2001. p. 144.

${ }^{20}$ TEIXEIRA DE FREITAS, Augusto. Esboço de Código Civil, p. 37.
} 
nascituro é sempre tratado com independência (...). O nascituro tem direitos, mas se o reconhecimento deles não for prático, nem lhe for vantajoso, desconsidera-se a sua própria existência na natureza (in rerum natura). Se vantajoso, considera-se já nascido, já na realidade humana (in rebus humanis). Esta assertiva, que parece não ter sido objeto específico de consideração pela doutrina até os dias de hoje, emana direta e constantemente das fontes e, para nós, serve como premissa para o entendimento dos direitos do nascituro. ${ }^{21}$

Sugere, por fim, uma revisão não das fontes, mas sim das interpretações dadas a elas.

Por fim, deve ser dada especial atenção à conclusão de Silmara Juny de Abreu Chinellato que, em estudo aprofundado sob o tema do nascituro, assim ensina

\begin{abstract}
Se o Direito Romano atribuiu direitos ao nascituro, e, entre eles, alguns não dependiam como não dependem - do nascimento com vida, não é aceitável a teoria que sustenta que no Direito Romano o nascituro não era sujeito de direitos, não tinha personalidade. ${ }^{22}$
\end{abstract}

Conforme se verifica, os doutrinadores divergem sobre a interpretação das fontes no Direito romano. Mas embora do exposto extraia-se que a divergência doutrinária quanto às fontes do Direito romano sobre o nascituro ainda persiste, todos os estudiosos no assunto apontam para o reconhecimento de direitos e interesses do nascituro (que eram protegidos por meio da curatela ao nascituro), sendo inegável que ele recebia um tratamento diferenciado daqueles que não podiam participar das relações jurídicas, tais como os escravos. É, portanto, impossível negar a existência de direitos próprios do nascituro e o respeito conferido à sua natureza humana encontrados no Direito romano.

\footnotetext{
${ }^{21}$ MACIEL, Hélcio. O nascituro no direito romano: conceito, terminologia e princípios, p. 102.

${ }^{22}$ CHINELLATO, Silmara Juny de Abreu. Tutela Civil do Nascituro. São Paulo: Saraiva, 2000. p. 34.
} 


\section{DISTINÇÕES CONCEITUAIS}

\subsection{Conceito de Nascituro e de Prole Eventual}

Conceituar é a "ação de formular uma idéia por meio de palavras”, 23 é definir, caracterizar. Um conceito nunca é estanque, podendo sofrer as adaptações necessárias frente a uma nova realidade. Nesta monta, não foge à regra o clássico conceito de nascituro de "pessoa por nascer já concebida no ventre materno", ${ }^{24}$ que, face ao avanço da biomedicina, passou a reclamar algumas alterações, relacionadas, principalmente, ao aperfeiçoamento das técnicas reprodutivas. A modificação conceitual proeminente se dá por conta da amplitude que o termo nascituro pôs-se a exigir nas últimas décadas. Da suficiente conceituação do nascituro como sendo o ser humano concebido in anima nobile, até por ter sido este, até então, o único modo de procriação conhecido, para a novidade da reprodução humana assistida e o auxílio de suas técnicas, de modo a possibilitar a fecundação in vitro, passou-se a questionar se a definição de nascituro deveria englobar também a do ser concebido fora do ventre materno, ou seja, do embrião criopreservado, chamado de embrião pré-implantatório.

Nesse sentido, Silmara Juny de Abreu Chinellato, acompanhando tais avanços, nos trouxe um novo conceito: "nascituro é aquele que está por nascer, já concebido", complementando-o em seguida: “o conceito amplo de nascituro - o que há de nascer - pode abarcar tanto o implantado como o embrião pré-implantatório”. ${ }^{25}$ Assim, hoje, ao tratar de nascituro, devemos cuidadosamente observar em que sentido o fazemos, se sob o sentido amplo de nascituro ou sob um sentido mais restrito, referente apenas ao já concebido no ventre materno.

Seguindo essa linha, Mário Bigotte Chorão, autor português, também entende a expressão "nascituro" de forma ampla, como designativa de "fruto da geração humana desde a fecundação ao nascimento". Inclusive, atenta ao fato de que são utilizados diferentes termos na

\footnotetext{
${ }^{23}$ FERREIRA, Aurélio Buarque de Holanda. Novo Aurélio Século XXI: o dicionário da língua portuguesa. 3. ed. Rio de Janeiro: Nova Fronteira, 1999.

${ }^{24}$ TEIXEIRA DE FREITAS, Augusto. Esboço do Código Civil, p. 37, comentário ao artigo 53.

${ }^{25}$ CHINELLATO, Silmara Juny de Abreu. Estatuto jurídico do nascituro: o direito brasileiro. In: DELGADO, Mário Luiz; ALVES, Jones Figueirêdo. (Coord.). Questões Controvertidas no Novo Código Civil. v. 6. São Paulo: Método, 2007. p. 51.
} 
linguagem científica e vulgar, tais como zigoto, mórula, blástula, pré-embrião, embrião, feto, para se referir às diferentes fases de desenvolvimento do ser humano, independentemente de seu locus, quer in vitro, quer in vivo, todos podendo ser englobados pelo termo jurídico nascituro. ${ }^{26}$

Frente aos avanços da biomedicina e da reprodução humana assistida, portanto, observamos que o conceito de nascituro sofreu transformação, uma vez que a ele acrescentou-se a possibilidade de englobar o embrião pré-implantatório.

Diante dessa nova realidade, poder-se-ia questionar qual o significado dado à expressão “nascituro", prevista no artigo $2^{\circ}$ do Código Civil. O entendimento tradicional do termo remonta apenas ao embrião já concebido no ventre materno, uma vez que foi esta a intenção do legislador quando da redação do Código Civil atual. ${ }^{27}$ A opção do artigo $2^{\circ}$ do Código Civil de 2002 pelo antigo entendimento do termo se justifica, já que por ocasião da apresentação do projeto final do Código, em 1975, ainda não havia nascido o primeiro bebê de proveta (Louise Brow) que veio ao mundo apenas em 1976, não havendo, destarte, questionamento significante sobre a possibilidade de concepção fora do útero materno no meio jurídico àquela época, quanto mais qualquer ideia da repercussão que esta possibilidade iria causar na interpretação do termo concepção, previsto no referido artigo.

Após a entrada em vigor do Código Civil, em 2002, em virtude da familiaridade com esta nova situação e da ânsia de proteger os direitos do embrião pré-implantatório de forma a não deixar dúvidas na doutrina, surgiram propostas de alteração do artigo $2^{\circ}$ do Código para inclusão expressa do termo “embrião”. No entanto, quanto a esta proposta, Silmara Juny de Abreu Chinellato expressa a opinião de que

o embrião é apenas um dos estágios de desenvolvimento do ovo (zigoto, mórula, blástula, embrião e feto). Acrescentar no art. $2^{\circ}$ a palavra não-jurídica e restritiva "embrião" significa negar a qualidade de nascituro que já tem. ${ }^{28}$

Tecnicamente temos que nascituro é um conceito jurídico que não se confunde com o de embrião, que é conceito médico a evidenciar uma das fases de desenvolvimento do ser humano. Disso decorre que a expressão nascituro também engloba o embrião pré-implantatório.

\footnotetext{
${ }^{26}$ CHORÃO, Mário Bigotte. Pessoa humana, direito e política. Lisboa: Imprensa Nacional - Casa da Moeda, 2006. p. 421.

${ }^{27}$ Nesse sentido, há proposta de projeto de lei modificador do artigo $2^{\circ}$ do Código Civil (Projeto de Lei n. 6960, reapresentado sob o n. 276/2007, após falecimento do Deputado Ricardo Fiuzza), para nele acrescentar o termo "embrião”, se não vejamos: “art. $2^{\circ}$. A personalidade civil da pessoa começa do nascimento com vida; mas a lei põe a salvo, desde a concepção, os direitos do embrião e os do nascituro".

${ }^{28}$ CHINELLATO, Silmara Juny de Abreu. Estatuto jurídico do nascituro: o direito brasileiro, p. 48.
} 
Entretanto, por ser o tema cheio de debates, não se esgota apenas no que se refere à amplitude do termo nascituro. Certo é que uma vez que temos a possibilidade de reproduzir a fecundação humana in vitro, fora do ventre materno, avançando o desenvolvimento do embrião até momentos ainda não conhecidos, torna-se impossível não indagar se o embrião in vitro há de ser considerado ou não pessoa, inclusive para todos os fins de direito.

Maria Helena Diniz, embora conceitualmente se valha do termo embrião para se referir ao fruto da fecundação extrauterina e do termo nascituro para designar o ser concebido já no ventre materno, entende que o início da personalidade jurídica se verifica no momento da concepção, seja extra ou intrauterina, pelo fato de o embrião já apresentar carga genética diferenciada desde esse momento, e, tendo em vista que os direitos da personalidade, como o direito à vida, à integridade física e à saúde, independem do nascimento com vida. ${ }^{29}$

Silmara Juny de Abreu Chinellato entende que, embora o termo nascituro englobe o embrião extra ou intrauterino: “a lei poderá distinguir a capacidade do nascituro implantado do não implantado". 30

A dúvida quanto à natureza jurídica e ética do embrião pré-implantatório sai do campo meramente teórico e, como ressalva Silmara Juny de Abreu Chinellato, “é um dos temas que mais provoca polêmicas na Bioética e no Biodireito”. 31 Embora, tal tema, não vá ser estudado em pormenores neste trabalho, por ser de grande complexidade e por si só dar ensejo a uma monografia própria. De qualquer forma, apenas para reforçar a relevância prática da determinação da natureza jurídica do embrião pré-implantatório, podemos citar exemplo trazido por Fábio Ulhoa Coelho, que se refere à possibilidade de implementação de embrião in vitro no útero da mulher em ocasião post mortem do genitor e às consequências para o direito sucessório, posto que a depender da natureza de sujeito de direitos do embrião pré-implantatório poderá ser ele considerado para fins sucessórios antes mesmo de sua implementação no útero materno, devendo ser-lhe, para tanto, nomeado curador. ${ }^{32}$

Por ser questão mais complexa do que aparenta, o objeto ventilado foi, inclusive, alvo de debate no Supremo Tribunal Federal, que, em abril de 2007, convocou uma audiência pública

\footnotetext{
${ }^{29}$ DINIZ, Maria Helena. Curso de Direito Civil Brasileiro: teoria geral do direito civil. v. 1. 23. ed, São Paulo: Saraiva, 2006. p. 196-198.

${ }^{30}$ CHINELLATO, Silmara Juny de Abreu. Estatuto jurídico do nascituro: o direito brasileiro, p. 48.

${ }^{31}$ Idem. Adoção de nascituro e a quarta era dos direitos: razões para se alterar o caput do artigo 1.621 do Novo Código Civil. In: DELGADO, Mário Luiz; ALVES, Jones Figueirêdo. (Coord.). Questões Controvertidas no Novo Código Civil, v. 1, p. 366.

${ }^{32}$ COELHO, Fábio Ulhoa. Curso de Direito Civil. v. 1. São Paulo: Saraiva, 2003. p. 149.
} 
para discutir a questão dos embriões pré-implantatórios e o início da vida frente a uma ação direta de inconstitucionalidade proposta em maio de 2005 pelo então procurador-geral da República, Cláudio Fonteles. A ação havia sido proposta contra o artigo $5^{\circ}$ da controvertida Lei de Biossegurança, ${ }^{33}$ que trata da possibilidade de pesquisa científica em embriões humanos, vislumbrando a imprescindível resposta de viés jurídico acerca do assunto, o qual teve, por fim, declarada sua constitucionalidade com o julgamento de improcedência da ação direita de inconstitucionalidade. Prevaleceu o entendimento do relator de que "um embrião congelado, que jamais será gerado, não pode gozar dos direitos de proteção da vida e da dignidade da pessoa humana”, ${ }^{34}$ Em que pese a polêmica em torno da opinião do digníssimo relator, como dito, sobre os embriões pré-implantatórios não serão feitas maiores observações, por ser centro de discussão muito ampla que demanda trabalho próprio e foge do objeto de nosso estudo, restrito ao nascituro enquanto ser concebido já no ventre materno.

Cabe, ainda, a observação de que não parece ser papel do Código Civil especificar em minúcias todas as situações possíveis, pois é notório que o positivismo exagerado engessa o Direito, cabendo ao intérprete fazer a norma acompanhar a realidade. Nesse sentido, temos a opinião de Ricardo Fiúza, que nos alerta quanto à importância da hermenêutica jurídica, defendendo que questões não consolidadas, como a dos embriões, não devem ser reguladas pelo Código Civil, uma vez que em curto espaço de tempo o avanço científico superaria o da norma legal, devendo o Código Civil trazer comandos abertos que não se defasam em função da velocidade das grandes transformações sociais e políticas. ${ }^{35}$

Exposta essa primeira dificuldade, resta-nos diferenciar brevemente o conceito de nascituro e o de prole eventual, que não se confundem.

A prole eventual é prevista no artigo 1.799 do Código Civil de 2002, o qual regula a possibilidade de alguém deixar em testamento bens aos filhos ainda não concebidos de pessoas determinadas pelo testador, desde que vivas estas quando da abertura da sucessão.

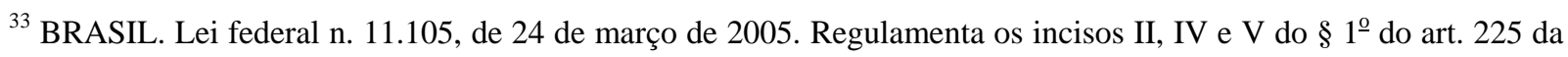
Constituição Federal, estabelece normas de segurança e mecanismos de fiscalização de atividades que envolvam organismos geneticamente modificados - OGM e seus derivados, cria o Conselho Nacional de Biossegurança CNBS, reestrutura a Comissão Técnica Nacional de Biossegurança - CTNBio, dispõe sobre a Política Nacional de Biossegurança - PNB, revoga a Lei n⿳0 8.974, de 5 de janeiro de 1995, e a Medida Provisória $n^{0}$ 2.191-9, de 23 de

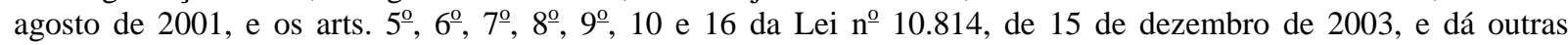
providências. D.O.U. 28.03.2005. A Lei n. 11.105/2005 foi questionada na ADIn n. 3510.

${ }^{34} \mathrm{O}$ inteiro teor da ADIn n. 3510 está disponível em: <www.stf.jus.br>. Acesso em: 10 dez. 2009.

${ }^{35}$ Cf. FIUZA, Ricardo (Coord.). Novo Código Civil Comentado. São Paulo: Saraiva, 2005.
} 
Referindo-se à prole eventual, Serpa Lopes assim expõe:

Quando se trata de indivíduos não concebidos, só em uma hipótese podem eles, se nascerem, adquirir um direito surgido anteriormente: é se pertencerem à prole eventual de pessoas designadas pelo testador e existentes ao abrir-se a sucessão, pois do contrário, são absolutamente incapazes de adquirir por testamento (ou por outro qualquer título) os indivíduos não concebidos até a morte do testador. ${ }^{36}$

O nascituro, por sua vez, ser já concebido, tem seus direitos resguardados desde a concepção, conforme previsão legal.

Teixeira de Freitas já diferenciava o nascituro da prole eventual (a "pessoa por nascer" da "pessoa futura”), considerando que o nascituro já existe por estar no ventre materno, embora ainda não tenha nascido, e que a prole eventual ou futura, por sua vez, não seria pessoa, porque não existe. ${ }^{37}$

Em suma, a diferença entre nascituro e prole eventual reside no fato de que em relação à prole eventual ainda não houve a concepção, enquanto o nascituro é o ser já concebido, é a pessoa em desenvolvimento, já existente. Prole eventual, portanto, não passa de mera expectativa de vir a existir. E, nesse sentido, em nada se assemelha ao nascituro.

\subsection{Pessoa, Personalidade e Capacidade}

Sobre o dilema relativo ao início da personalidade jurídica - se se efetiva desde a concepção ou somente após o nascimento com vida -, já chamavam a atenção para o tema André Franco Montoro e Anacleto de Oliveira Faria, em sua pioneira obra Condição Jurídica do Nascituro no Direito Brasileiro. Na tentativa de desvendar todos os percalços envolvidos, vamos primeiramente traçar algumas distinções conceituais que se fazem necessárias sobre pessoa, personalidade e capacidade.

O vocábulo pessoa pode englobar diversos significados, a depender do enfoque dado, mas qualquer que seja atualmente a acepção dada a tal palavra - jurídica, filosófica ou científica -, certo é que envolve o ser humano individualmente considerado.

\footnotetext{
${ }^{36}$ SERPA LOPES, Miguel Maria de. Curso de Direito Civil: introdução, parte geral e teoria dos negócios jurídicos. 7. ed. Rio de Janeiro: Freitas Bastos, 1989. p. 252.

37 TEIXEIRA DE FREITAS, Augusto. Esboço do Código Civil, p. 37.
} 
Na Antiguidade, o termo tinha uma essência diferente. Conforme exposto por Washington de Barros Monteiro, ${ }^{38}$ a palavra pessoa veio do latim persona e, originalmente, simbolizava a máscara usada pelo ator na Antiguidade romana, durante uma encenação teatral, de forma a dar eco à sua voz, fazendo-a soar com maior intensidade. Posteriormente, passou a ser utilizada para designar a personagem que o ator representava no teatro, o que, por analogia, no cenário jurídico, expressava a atuação de cada indivíduo na vida, explicitando seu status na sociedade. Atualmente, em um sentido ontológico, tal palavra é empregada para definir o próprio indivíduo.

Juridicamente, o termo pessoa recebe uma atenção especial, uma vez que todas as regras jurídicas só existem no sentido de regular as relações humanas. E definir, portanto, quem é pessoa para o Direito, ou seja, quem terá possibilidade de integrar um dos polos de uma relação jurídica, é a base para a análise do início da personalidade jurídica.

Teixeira de Freitas, primeiro jurista convidado a elaborar um Código Civil brasileiro, em seu Esboço já afirmava que "todos os entes suscetíveis de aquisição de direitos são pessoas”. 39 Sugeriu ainda uma classificação de pessoa com nomenclatura diferente daquela até então utilizada, dividindo-a em dois grupos, de “existência visível” e de “existência tão somente ideal”, referindo-se, respectivamente, a pessoas naturais e jurídicas, por entender serem aqueles termos mais adequados que estes. ${ }^{40}$

Clóvis Bevilaqua, elaborador do Código Civil de 1916, por sua vez, nos trouxe o tradicional conceito de pessoa que perdura até os dias atuais, qual seja: “pessoa é o ser a que se atribuem direitos e obrigações”. ${ }^{41}$ Mas, embora possamos afirmar que por pessoa entende-se o ente (natural ou jurídico) capaz de adquirir direitos e obrigações, podendo ser usado como sinônimo de sujeito de direitos, ${ }^{42}$ no que tange às pessoas naturais devemos fazer a leitura de tal conceito à luz da Constituição, na qual entende-se igualmente por pessoa todos os seres humanos, não existindo nenhuma condição ou status definidor. E é nessa linha civilista-constitucionalista que se deve ler o artigo $1^{\circ}$ do Código Civil de 2002, que assim preceitua: “toda pessoa é capaz de direitos e deveres na ordem civil”.

\footnotetext{
${ }^{38}$ MONTEIRO, Washington de Barros. Curso de Direito Civil. v. 1. 37. ed. São Paulo: Saraiva, 2000. p. 56.

${ }^{39}$ TEIXEIRA DE FREITAS, Augusto. Esboço do Código Civil, Artigo 16.

${ }^{40}$ A doutrina adotou diferentes classificações para se referir aos mesmos dois grupos de pessoas. De um lado podemos citar as chamadas pessoas naturais, físicas ou de existência visível; e de outro as pessoas jurídicas, morais ou ideais. O nosso Código Civil atual adotou a classificação que diferencia pessoas naturais de pessoas jurídicas.

${ }^{41}$ BEVILAQUA, Clóvis. Teoria Geral do Direito Civil. Servanda: Campinas, 2007. p.91.

${ }^{42}$ DINIZ, Maria Helena. Curso de Direito Civil Brasileiro, v. 1, p. 117.
} 
Sob um aspecto de valoração de princípios humanistas, no nosso atual entendimento jurídico-cultural poder-se-ia afirmar que todos os homens são pessoas para o direito. Muito embora seja essa a realidade que se almeja alcançar na cultura ocidental, ainda encontramos entraves no que diz respeito ao nascituro, conforme demonstraremos ao longo deste trabalho.

Cabe ainda a ressalva de que será objeto de nosso estudo apenas a chamada pessoa natural (o ser humano), em contraposição à chamada pessoa jurídica ou ideal (associações, sociedades, fundações, organizações religiosas e os partidos políticos), entes morais para os quais a lei atribui personalidade jurídica. ${ }^{43}$ Não perdemos de vista, contudo, que como uma conquista do reconhecimento dos direitos humanos e do desenvolvimento do valor dignidade humana, atualmente a todos os seres humanos se reconhece a qualidade de pessoa como sujeito de direitos.

Atrelado ao conceito de pessoa temos o de personalidade jurídica.

Conforme ensina Orlando Gomes, personalidade consiste em um atributo jurídico da pessoa, podendo ser definida como a aptidão para que o sujeito figure como titular de direitos e obrigações ou como a possibilidade de desempenhar na sociedade um papel jurídico. ${ }^{44}$

Fábio Ulhoa Coelho, com entendimento peculiar sobre o assunto, numa tentativa de justificar a possibilidade de certos entes sem personalidade jurídica serem titulares de direitos e obrigações, adota diferente conceituação entre sujeito de direito e pessoa, aceitando a possibilidade da existência de um sem o outro, embora ele mesmo reconheça que a maioria doutrinária tome os dois termos por sinônimos. Para tanto, delineia sujeito de direito como um “centro de imputação de direitos e obrigações pelas normas jurídicas”, trazendo à baila o entendimento de que sujeito de direito é gênero e pessoa espécie; podendo existir, portanto, sujeito de direito não personalizado. ${ }^{45}$ Exemplifica como sujeitos de direito as pessoas naturais, o nascituro, as pessoas jurídicas, o condomínio edilício e a massa falida; sendo apenas as pessoas naturais e as pessoas jurídicas sujeitos de direito personalizados, não tendo os demais mencionados personalidade jurídica, embora possam ser titulares de direitos e obrigações. E para fundamentar tal entendimento, que traz um critério diferente de classificação de sujeito de direito,

\footnotetext{
${ }^{43}$ O termo “pessoa moral” é uma terminologia do sistema francês, utilizada para distinguir a pessoa natural (ser humano) dos outros titulares (sujeitos) de direito.

${ }^{44}$ GOMES, Orlando. Introdução ao Direito Civil. Rio de Janeiro: Forense, 2008. p. 126.

${ }^{45}$ COELHO, Fábio Ulhoa. Curso de Direito Civil, v. 1, p. 138.
} 
divide-os em sujeitos humanos (corpóreos) e não humanos (incorpóreos), ou personalizados e não personalizados. Encaixa-se o nascituro, nessa monta, como sujeito humano despersonalizado. ${ }^{46}$

Conclui, por fim, que embora nem todo sujeito de direito tenha personalidade jurídica, independentemente de sua classificação, todo sujeito de direito teria aptidão para ser titular de direitos e obrigações, justificando assim a possibilidade de o nascituro ter direitos, uma vez que, para o autor, embora o nascituro seja sujeito humano, é despersonalizado, não detendo personalidade jurídica. ${ }^{47}$

Mas tal opinião díspar não deve prosperar, pois, além de minoritária, quando não isolada, encontra diversos entraves lógicos - inclusive no novo entendimento constitucional de que todo ser humano é pessoa e tem personalidade jurídica e no civilista de que todo sujeito de direito possui personalidade jurídica. Podemos afirmar ser impossível haver sujeito de direto sem personalidade jurídica, já que esta é inerente àquele.

Embora, atualmente, nos países ocidentais entenda-se que toda pessoa seja dotada de personalidade, nem sempre foi assim, existindo algumas exceções históricas, como o instituto da escravidão no Direito romano. ${ }^{48}$ Não se entendia personalidade jurídica como um atributo de todas as pessoas, mas sim como atributo criado e outorgado pela lei civil apenas a quem detivesse determinadas condições.

Por este motivo que Roxana Cardoso Brasileiro Borges prefere falar em personalidade como um valor jurídico ou princípio e não como mero atributo. A autora entende que o conceito de personalidade passou por grandes alterações valorativas no Direito brasileiro, estando hoje ligado à dignidade da pessoa humana, não sendo considerado mais como mero requisito para que certo ente ingresse no mundo jurídico e seja reconhecido como sujeito de direitos e deveres. ${ }^{49}$

Nesse sentido, conforme já ensinava San Tiago Dantas, o conceito antigo de personalidade - como a capacidade que tem um homem de direitos e obrigações - seria o hodiernamente utilizado para capacidade jurídica, enquanto a personalidade, sob uma perspectiva

\footnotetext{
${ }^{46}$ COELHO, Fábio Ulhoa. Curso de Direito Civil, v. 1, p. 139.

${ }^{47}$ Ibidem, v. 1, p. 141.

48 Ainda hoje encontramos países e culturas em que nem todo ser humano é tratado com igualdade ou tem reconhecida sua personalidade jurídica, tais como, por exemplo, os países islâmicos e africanos, nos quais as mulheres ainda hoje recebem tratamento discriminatório.

${ }^{49}$ BORGES, Roxana Cardoso Brasileiro. Direitos da Personalidade e Dignidade: da responsabilidade civil para a responsabilidade constitucional. In: DELGADO, Mário Luiz; ALVES, Jones Figueirêdo (Coord.). Questões Controvertidas no Novo Código Civil, v. 5, p. 558.
} 
mais moderna, significaria o conjunto dos atributos humanos, como a vida, a integridade corpórea, a liberdade. ${ }^{50}$

Sobre esta questão, Mário Bigotte Chorão atenta e ressalta a evidente diversidade de entendimento quanto à personalidade jurídica a depender do pensamento filosófico adotado. Conforme o autor, numa visão extremamente positivista e formalista com bases doutrinais na Pandectística, em Savigny, em Kelsen e ainda hoje, em alguns doutrinadores tradicionalistas, teríamos a personalidade jurídica como um atributo puramente criado pela lei, não correspondente, necessariamente, a todos os seres humanos. Dependeria sua existência, no caso da pessoa natural, do nascimento com vida, não sendo o nascituro verdadeiro sujeito de direitos, pois assim determinado pela lei. Por outro lado, numa concepção realista, personalista e jusnaturalista, da qual o autor é adepto e defensor, a personalidade jurídica deve ser encarada como um atributo inerente, por natureza, à pessoa em sentido ontológico, sendo que, nesse sentido, a existência da personalidade jurídica remontaria ao tempo da concepção, sendo o nascituro sujeito de direitos. ${ }^{51}$

Nesse sentido, Fábio Konder Comparato ensina que a essência do ser humano é evolutiva e sua personalidade está em constante evolução, não sendo permanente e imutável, mas sim incompleta, em contínua transformação. ${ }^{52}$

Hoje, na nossa atual realidade, busca-se o reconhecimento pelo direito da personalidade jurídica a todos os seres humanos de maneira igualitária, conforme pode-se extrair do já citado artigo $1^{\circ}$ do Código Civil.

Logo, podemos afirmar que a personalidade jurídica é um atributo ou uma qualidade inerente à condição de pessoa natural, bem como é concedida pela legislação civil aos entes morais por ela criada.

Retomando, ter personalidade jurídica significa a possibilidade de aquisição de direitos e obrigações. E, conforme visto, toda pessoa (ser humano) é dotada de personalidade simplesmente por existir, sendo pessoa sinônimo de sujeito de direitos. ${ }^{53}$

Não esquecendo, conforme lembrado por Maria Celina Bodin de Moraes, que as normas civilistas devem ser vistas sob a ótica dos valores constitucionais fundamentais da pessoa

\footnotetext{
${ }^{50}$ SAN TIAGO DANTAS, F. C. Programa de Direito Civil: parte geral. Rio de Janeiro: Editora Rio, 1979. p. 191.

${ }^{51}$ CHORÃO, Mário Bigotte. Pessoa humana, direito e política, p. 433-434.

52 COMPARATO, Fábio Konder. A afirmação histórica dos direitos humanos. 4. ed. São Paulo: Saraiva, 2006. p. 29.

${ }^{53}$ AMARAL, Francisco. Direito Civil: Introdução. 3. ed. Rio de Janeiro/São Paulo: Renovar, 2000. p. 215.
} 
humana, de sua dignidade, de sua personalidade e de seu livre desenvolvimento, ${ }^{54}$ o que nos leva a fazer a análise dos conceitos de pessoa e personalidade até agora vistos sempre de forma a exaltar e firmar o respeito da dignidade da pessoa humana em todas as suas formas. ${ }^{55}$

Por fim, ainda nos resta traçar a diferença entre personalidade e capacidade, que, embora sejam termos conexos, não têm mesmo sentido. Ao tratar dessa diferença bem explanou Francisco Amaral, que assim nos traz: "Enquanto a personalidade é um valor, a capacidade é a projeção desse valor que se traduz em um quantum. Pode-se ser mais ou menos capaz, mas não se pode ser mais ou menos pessoa”. ${ }^{56}$ Capacidade, portanto, conforme já prelecionava Clóvis Bevilaqua, é a extensão dada à personalidade. ${ }^{57}$

De forma complementar aos estudos aqui realizados, é importante observar que existem dois tipos de capacidade: a capacidade de direito (de gozo), que é inerente à personalidade, e a capacidade de fato (de exercício), que não é própria de toda pessoa, detendo-a apenas os sujeitos de direito que estão aptos para o exercício dos atos da vida civil. É a capacidade de exercício que é atributo da personalidade, por identificar o sujeito de direito na exata medida em que regula quem é mais ou menos capaz para tal ou qual ato da vida civil. ${ }^{58}$

Devemos ainda atentar para o fato de que, embora seja este o entendimento de grande parte da doutrina contemporânea sobre o assunto no que tange às diferenças traçadas entre personalidade e capacidade, a questão não está pacificada, restando ainda a influência de

\footnotetext{
${ }^{54}$ MORAES, Maria Celina Bodin de. A Caminho de um Direito Civil Constitucional. Revista de Direito Civil, v. 17, n. 65, p. 26, jul./set. 1993.

${ }^{55}$ Em auxílio a essa visão constitucionalista do Código Civil, Rafael Garcia Rodrigues traz a seguinte elucubração: "Há que ser entendida a personalidade em suas duas expressões ou sentidos. A primeira, da qual decorre a possibilidade de ser sujeito de direito e obrigações, conferida não apenas aos homens, mas também, de acordo com a técnica legislativa, às empresas, associações, fundações, enfim aos agrupamentos de indivíduos aos quais o direito confere personalidade (pessoas jurídicas). É importante frisar, desde logo, que personalidade não poderia confundirse com a mera possibilidade de ser sujeito de direito, pois assim estaríamos a assemelhar e a admitir a tutela das pessoas físicas (o ser humano) sob o mesmo plano valorativo daquela a ser conferida às pessoas jurídicas, o que é de todo inadmissível.

O segundo sentido de personalidade se associa a expressão do ser humano, traduzido como valor objetivo, interesse central do ordenamento e bem juridicamente relevante. Trata-se do reconhecimento da personalidade como valor ético emanado do princípio da dignidade da pessoa humana e da consideração pelo direito civil do ser humano em sua complexidade. Logo, podemos afirmar que a personalidade não se resume à possibilidade de ser titular de direitos e obrigações, ou seja, ao conceito abstrato de pessoa próprio do ideário oitocentista, importando no reconhecimento de direitos que tocam somente ao ser humano, expressão de sua própria existência”. RODRIGUES, Rafael Garcia. A pessoa e o ser humano no Código Civil. In: TEPEDINO, Gustavo (Coord.). A parte Geral do Novo Código Civil: estudos na perspectiva Civil-Constitucional. Rio de Janeiro: Renovar, 2007. p. 1-34.

${ }^{56}$ AMARAL, Francisco. Direito Civil: Introdução, p. 216.

${ }^{57}$ BEVILAQUA, Clóvis. Teoria Geral do Direito Civil, p. 81.

${ }^{58}$ NERY JÚNIOR, Nelson; NERY, Rosa Maria de Andrade. Código Civil Comentado. 6. ed. rev., ampl. e atual. São Paulo: Revista dos Tribunais, 2008. p. 199.
} 
posicionamentos de consagrados autores em sentido contrário. Caio Mário da Silva Pereira, em seu Curso de Direito Civil, por exemplo, aduz que a ideia de capacidade estaria diretamente atrelada à de personalidade, sendo conceitos complementares, cada qual não se valendo sem o outro. $^{59}$ Nesse sentido também prelecionava Miguel Maria de Serpa Lopes, para quem a capacidade jurídica seria um atributo da pessoa, ou seja, sinônimo de personalidade. ${ }^{60}$ Mas em combate a essa corrente de pensamento, podemos utilizar os argumentos de Arnaldo Rizzardo, para quem "equivocam-se aqueles que fazem depender o exercício da personalidade do exercício da capacidade”, complementando que “o pleno exercício dos direitos da personalidade não está na dependência de ser ou não capaz a pessoa”. 61

Para esta confusão já alertava Vicente Ráo, aduzindo que a redação do nosso Código Civil foi influenciada pelo fato de os autores europeus usarem a expressão “capacidade jurídica” (de direito) no sentido de personalidade. ${ }^{62}$

Portanto, conforme já ensinava Limongi França, entre outros, capacidade é apenas uma característica da personalidade que causa repercussão jurídica, é um atributo da personalidade jurídica, mas desta se distingue, uma vez que personalidade jurídica é uma qualidade do ente que se considera pessoa, ${ }^{63}$ podendo, inclusive, haver personalidade sem capacidade ${ }^{64}$ e não devendo, portanto, prosperar a definição que atrela capacidade à personalidade.

Resumindo, temos que para ser pessoa basta existir; existindo para o mundo jurídico, toda pessoa é dotada de personalidade, que é uma qualidade da mesma, e a capacidade vai ser a medida dessa personalidade, uma expansão que causa repercussão jurídica.

Feitas essas primeiras diferenciações entre pessoa, personalidade e capacidade, chegamos à conclusão de que toda pessoa detém personalidade jurídica, mas nem toda pessoa é capaz de fato.

Passamos agora a abordar o tema referente ao início da existência da pessoa para o mundo jurídico.

\footnotetext{
${ }^{59}$ PEREIRA, Caio Mário da Silva. Instituições de Direito Civil, v. 1, passim.

${ }^{60}$ SERPA LOPES, Miguel Maria de. Curso de Direito Civil, v. 1, p. 247-250.

${ }^{61}$ RIZZARDO, Arnaldo. Parte Geral do Código Civil. 5. ed. Rio de Janeiro: Forense, 2007. p. 194.

${ }^{62}$ RÁO, Vicente. O Direito e a vida dos direitos. 5. ed. anotada e atual. por Ovídio Rocha Barros Sandoval. São Paulo: Revista dos Tribunais, 1999. p. 652.

${ }^{63}$ LIMONGI FRANÇA, Rubens. Manual de Direito Civil. v. 1. São Paulo: Revista dos Tribunais, 1980. No mesmo sentido: DINIZ, Maria Helena. Curso de Direito Civil Brasileiro, v. 1, p. 119; MONTEIRO, Washington de Barros. Curso de Direito civil, v. 1, p. 59; GOMES, Orlando. Introdução ao Direito Civil, p. 149.

${ }^{64}$ AMARAL, Francisco Direito Civil: Introdução, p. 216.
} 


\subsection{Início da Vida e Início da Personalidade Jurídica}

O início da vida e o da personalidade jurídica são as grandes questões de fundo que permeiam a presente dissertação. Mas, de início, cabe-nos apenas apresentar a dificuldade do tema, que será explorado com maior profundidade em capítulo próprio.

Ambos os conceitos não se confundem. O início da vida se reporta ao momento inicial de formação e desenvolvimento do ser humano, o que depende do ponto de vista adotado científico, religioso ou filosófico. Já o início da personalidade jurídica, conforme vamos verificar adiante, alude ao momento inicial em que o direito confere proteção jurídica ao ser humano e lhe reconhece a qualidade de pessoa.

O início da vida humana é questão altamente debatida na sociedade, sendo ainda um conceito indeterminado e não pacífico. Quanto ao seu momento inicial, como dito, podemos encontrar diversas posições filosóficas, religiosas e científicas que devem ser levadas em conta no momento de elaboração da norma que irá determinar o início da personalidade jurídica.

Cientificamente, embora hoje seja possível não só precisar com exatidão o momento da concepção, mas também fazer o completo acompanhamento das diversas fases evolutivas da gestação e até cogitar a possibilidade de reproduzi-las de forma artificial (por meio da controvertida e ainda insipiente técnica da clonagem humana), ainda não há consenso sobre o momento inicial da vida humana.

Quando se deve reconhecer a existência de um homem?

Baseados na ciência, temos hoje a possibilidade de saber exatamente quando ocorre a fecundação e o início do desenvolvimento do ser humano, mas seria o momento da fecundação o momento inicial da vida humana? Médicos, cientistas, especialistas em reprodução humana apontam vários critérios. Uns adotam o critério celular, pelo qual reconhecem a vida desde a fecundação; outros reconhecem o início da vida a partir do momento em que há a implantação do ovo no útero (cerca de oito dias após a fecundação, com a nidação); neurocientistas defendem que o início da vida acompanha a formação do cérebro (duas semanas após a fecundação); outros adotam o critério cardíaco, relegando o princípio da vida ao momento em que o coração começa a bater (o que ocorre em torno da $4^{a}$ semana de gestação), entre outros entendimentos.

A religião também adota posições diferenciadas: para católicos e protestantes, por exemplo, a vida começa com a fecundação; para islamitas a vida começa na $16^{\text {a }}$ semana, quando 
o ser humano adquire uma alma; para os judeus a vida humana começa no parto, após o nascimento; para os budistas a vida seria um processo contínuo e ininterrupto.

Filósofos também adotaram critérios diferentes. Os filósofos pitagóricos, por exemplo, defendiam que a vida começava com a fecundação, e os estoicos, por sua vez, entendiam que a vida humana começava no parto.

Não podiam ser diferentes as legislações, que também adotam posicionamentos diferenciados; a lei espanhola, por exemplo, exige, além do nascimento com vida, 24 horas de sobrevivência para reconhecer o ser humano nascido como sujeito de direitos e obrigações; a legislação argentina, por sua vez, reconhece a personalidade jurídica desde a concepção.

Entre todos os critérios existentes (arbitrariamente defendidos), nenhum traduz uma verdade real, não se podendo afirmar que um é melhor que o outro, simplesmente porque cada qual se baseia no conhecimento da natureza, na fé, no pensamento humano ou na lei. Cada país, certamente, vai adotar a posição mais consente com seu pensamento. Mas com base nos conhecimentos científicos atuais sobre desenvolvimento humano, é impossível negar a natureza humana e diferenciada de um embrião e tendo em vista uma visão humanista de respeito à dignidade humana - independentemente do critério adotado -, deve-se considerar que é obrigação da sociedade a tutela do ser humano, qualquer que seja a fase de seu desenvolvimento.

Certo é que a definição jurídica não pode fechar os olhos para o conhecimento científico sobre o desenvolvimento do ser humano, devendo o Direito acompanhar a realidade fática e não ir contra ela. E embora juridicamente ainda haja divergência entre os doutrinadores do Direito quanto ao momento inicial da personalidade jurídica, não podemos negar ao nascituro a natureza de ser humano em desenvolvimento, tal qual se reconhece a um recém-nascido, a uma criança de tenra idade ou, ainda, a ser humano em qualquer fase de seu estágio vital.

Neste ponto, podemos nos questionar se a definição do momento inicial da vida humana se relaciona ao início da personalidade jurídica, e, inclusive, se tal relação pode ser feita. Desta monta, que traçamos as próximas considerações.

Primeiramente, não há que se esquecer o papel da norma, a qual tem por objetivo não somente regular as relações sociais, mas também atender às aspirações da sociedade. $\mathrm{O}$ ato de codificar, embora importante para a segurança das relações jurídicas, não deve engessar o regramento do direito, que deve acompanhar a dinâmica da vida em sociedade. Não deve o 
aplicador desta ciência ficar inerte às mudanças sociais, pois o fim da norma deve ir ao encontro da evolução da vida, adaptando-se a ela e não imobilizando-a.

Atualmente, a sociedade vive a nova realidade tecnológica, em que é possível se apoiar no conhecimento científico para melhorar a qualidade de vida do ser humano. E o Direito, ramo da ciência responsável pelo regramento das condutas em sociedade, tem sua importância ressaltada, devendo levar em conta os exemplos históricos experimentados, os quais revelam quão pouco se respeitou a dignidade das pessoas e quantos males foram permitidos em nome da ganância e do egoísmo. Frente à nova realidade biotecnológica, portanto, cabe ao legislador criar um novo regramento, e ao intérprete do Direito, aplicá-lo de forma consentânea com o respeito à pessoa humana.

Logo, temos que as ciências biológicas reaparecem de forma a clarear situações antes obscuras, como as que envolviam a reprodução humana, a gestação e o nascimento. Dessa maneira, o Direito deve acompanhar tais modificações, repensando seus antigos conceitos.

Isso em vista, podemos trazer à baila a crítica do autor português Diogo Leite de Campos, que entende estar a norma jurídica atual em defasagem com a nossa realidade. Critica o autor o entendimento tradicional de que a personalidade jurídica se inicia com o nascimento com vida, por estar atrasado, em descompasso com as descobertas tecnológicas sobre o desenvolvimento do ser humano. Sustenta a personalidade do já concebido e não nascido com grande veemência. Ainda, alerta ser o conceito tradicional pré-científico e baseada na ignorância da vida pré-natal. Alude também que não conferir personalidade jurídica ao nascituro seria “insustentável pela ciência contemporânea que sabe que a criança concebida é um ser humano”. 65

Nesse ponto, podemos encarar a discussão sobre o início da vida e o início da personalidade jurídica de duas formas: uma positivista e literal e outra humanista e sistemática. Na primeira, não há que se confundir o termo inicial exato da vida humana com o início da personalidade jurídica, posto que quanto a este último cada ordenamento jurídico irá definir quando se dará a existência da pessoa humana para o mundo jurídico e, consequentemente, da personalidade jurídica, devendo o legislador, portanto, atuar de forma a adequar o máximo possível tal concepção ao entendimento cultural predominante de seu país. Para quem assim entende, nosso ordenamento aparentemente segue tal filosofia, uma vez que temos o início da

${ }^{65}$ CAMPOS, Diogo Leite de. A capacidade sucessória do nascituro (ou a crise do positivismo legalista). In: CAMPOS, Diogo Leite de; CHINELLATO, Silmara Juny de Abreu. (Coord.). Pessoa Humana e Direito. Coimbra: Almedina, 2009. p. 49. 
personalidade civil determinado na parte primeira do artigo $2^{\circ}$ do Código Civil (ou seja, conforme critério do legislador), que assim dispõe: “a personalidade civil da pessoa começa do nascimento com vida”.

Na segunda visão, à qual nos filiamos, temos que o início da personalidade jurídica deve coincidir com o início da vida humana, já que todo ser humano deve ter a possibilidade de ser sujeito de direitos. Calcados nessa visão, temos as interpretações doutrinária e jurisprudencial do artigo $2^{\circ}$ que fogem à literalidade da lei e buscam, antes, uma visão sistêmica não só do Código Civil como de todo o ordenamento jurídico. O primeiro argumento nesse sentido encontra-se no próprio artigo $2^{\circ}$, que, em sua parte final, faz alusão a "direitos do nascituro" ao assim dispor: “(...) mas a lei põe a salvo, desde a concepção, os direitos do nascituro”, dando ensejo à possível conclusão de ser o nascituro pessoa, já que titular de direito, e, portanto, detentor de personalidade jurídica.

Concluindo, temos que, embora os conceitos de início da vida e início da personalidade jurídica não se confundam, estão interligados. Temos nítido que indicar quando se inicia a personalidade jurídica é tarefa difícil que deve ser feita sem perdermos de vista a possibilidade de conferir maior respeito e dignidade à vida humana como tal, uma vez que este é o fundamento maior de nossa República Federativa. É papel do Direito acompanhar a realidade e os conhecimentos atuais do desenvolvimento do ser humano, não podendo ir contra o mundo fenomênico. É papel do intérprete, por sua vez, conferir sentido à norma de modo a adaptá-la ao atual pensamento jurídico. 


\section{INÍCIO DA PERSONALIDADE JURÍDICA: PRINCIPAIS ESCOLAS DOUTRINÁRIAS}

A discussão sobre a natureza jurídica do nascituro já é há muito conhecida e tem proporcionado os mais diversos entendimentos, tanto na doutrina quanto na jurisprudência. Relacionada a tal quaestio, temos a problemática da definição do início da personalidade jurídica.

Podemos reunir os diversos posicionamentos doutrinários em 3 grandes grupos: a doutrina natalista, a doutrina da personalidade condicional e a doutrina verdadeiramente concepcionista. $^{66}$

A primeira, considerada conservadora e que tem como seus defensores Serpa Lopes, Orlando Gomes, Silvio Rodrigues, Caio Mário e Vicente Ráo, entre outros, defende que a personalidade civil começa com o nascimento com vida, considerando que o nascituro teria mera expectativa de direitos e negando-lhe, portanto, a qualidade de sujeito de direitos.

Nesse sentido, devemos proceder a alguns apontamentos.

Serpa Lopes refere-se ao nascituro como spes hominis e afirma que antes do nascimento não teria ele personalidade. ${ }^{67}$

Orlando Gomes, levando em conta o momento de existência da personalidade jurídica, classifica-a como real e ficta. A personalidade real coincidiria com a duração da vida humana, que, de acordo com o autor, começa com o nascimento e termina com a morte. A personalidade fictícia, por sua vez, corresponderia às demais hipóteses, nas quais a coincidência não se verificaria, tal como no caso do nascituro, do ausente e da pessoa cuja possibilidade de vir a existir é admitida para aquisição de direitos. ${ }^{68}$ Mas a personalidade fictícia seria apenas uma técnica legislativa visando à proteção de determinados interesses, não admitindo o autor ser o nascituro pessoa natural, conforme verificamos em seus próprios dizeres:

essas ficções atribuem personalidade porque reconhecem, nos beneficiados, a aptidão para ter direitos, mas é logicamente absurdo admitir a condição de pessoa natural em quem ainda não nasceu ou já morreu. Trata-se de construção técnica destinada a alcançar

\footnotetext{
${ }^{66}$ CHINELLATO, Silmara Juny de Abreu. O nascituro no Código Civil e no Direito Constituendo do Brasil. Revista de Direito Civil, Imobiliário, Agrário e Empresarial, São Paulo, n. 44, abr.jun. 1988, p. 182.

${ }^{67}$ SERPA LOPES, Miguel Maria de. Curso de Direito Civil, v. 1, p. 254.

${ }^{68}$ GOMES, Orlando. Introdução ao Direito Civil, p. 129. Nota-se que o autor equipara "nascituro" a "prole eventual".
} 
certos fins. Dilata-se arbitrariamente o termo inicial e final da vida humana, para que sejam protegidos certos interesses. ${ }^{69}$

Silvio Rodrigues, por sua vez, entende que a personalidade jurídica só se inicia com o nascimento com vida. Ao referir-se aos direitos do nascituro que a lei ressalva desde a concepção, o autor fala em "interesses futuros" e em "direitos que serão do nascituro", 70

Caio Mário, em determinado momento de sua obra, frisa que toda pessoa é dotada de personalidade, sendo que esta não depende da consciência ou da vontade do indivíduo. Em suas palavras:

a criança, mesmo recém-nascida, o louco, o portador de enfermidade que desliga o
indivíduo do ambiente físico ou moral, não obstante a ausência de conhecimento da
realidade ou a falta de reação psíquica, é uma pessoa, e por isso mesmo dotado de
personalidade, atributo inseparável do homem dentro da ordem jurídica, qualidade que
não decorre do preenchimento de qualquer requisito psíquico e também dele
inseparável.

Acrescenta que a ordem jurídica não só concede personalidade a todo ser humano, mas também a alguns entes morais por ela criados. E reconhece que o problema do início da personalidade está diretamente ligado ao início da existência do ser humano. ${ }^{72}$

No entanto, quando trata do início da existência do ser humano e, portanto, ao seu ver, da personalidade jurídica, ele critica o entendimento de Teixeira de Freitas e de Clóvis Bevilaqua, entre outros, que reconhecem a personalidade desde a concepção, sob a argumentação de que "o nascituro não é ainda uma pessoa, não é um ser dotado de personalidade jurídica. Os direitos que se lhe reconhecem permanecem em estado potencial”. ${ }^{73}$ Caio Mário entende que não se pode falar em "pessoa” do nascituro, sendo que apenas após o nascimento existe uma pessoa e, portanto, seria este o momento inicial da personalidade jurídica. A lei apenas cuidaria de proteger os interesses do nascituro, tendo em vista algumas circunstâncias. Conclui o seu entendimento afirmando que, até o nascimento com vida, o que existem são meros direitos potenciais. ${ }^{74}$

Outra formulação teórica do assunto que merece destaque é de Nelson Nery Jr. e Rosa Maria de Andrade Nery, para os quais o nascituro é visto como pessoa formal. Teria personalidade jurídica nos exatos termos da legislação civil em vigor (tal como o condomínio e a

\footnotetext{
${ }^{69}$ GOMES, Orlando. Introdução ao Direito Civil, p. 129.

${ }^{70}$ RODRIGUES, Silvio. Direito Civil: parte geral. v. 1. 34. ed. São Paulo: Saraiva, 2003. p. 36.

${ }^{71}$ PEREIRA, Caio Mário da Silva. Instituições de Direito Civil, v. 1, p. 142.

${ }^{72}$ Ibidem, v. 1, p.143-144.

${ }^{73}$ Ibidem, v. 1, p. 144-145.

${ }^{74}$ Ibidem, v. 1, p. 145.
} 
massa falida). Em comentário ao artigo $2^{\circ}$ do Código Civil, os juristas aduzem expressamente que:

tecnicamente o nascituro é ente não dotado de personalidade, mas que, pelo fato da gestação, pode assumir posição jurídica de vantagem em específicas situações jurídicas, como por exemplo: a) não ter interrompido sua gestação - direito de nascer; b) direito a alimentação; c) direito a registro; d) direito a representação (CC 1630 e 1634 VI); e) direito à curatela (CC 1779 caput e CPC 878 par. ún.); f) direito à sucessão (CC 1784 c/c 1793). ${ }^{75}$

De maneira geral, a grande crítica direcionada à corrente natalista refere-se ao fato de não explicar o porquê de a lei expressamente reconhecer ao nascituro "direitos” e não “expectativa de direitos”. ${ }^{76}$ E, por isso, atualmente esta corrente tem perdido sua força.

A segunda doutrina é chamada de teoria da personalidade condicional. Podemos afirmar que tal doutrina teve como predecessor Clóvis Bevilaqua.

Para essa corrente doutrinária, a personalidade é reconhecida desde a concepção, mas é condicionada ao nascimento com vida. Seus seguidores defendem que o nascituro teria direitos, e não meras expectativas de direitos, mas direitos subordinados a uma condição suspensiva consistente no nascimento com vida. Por defender uma posição intermediária, tem muitos adeptos.

Clóvis Bevilaqua trouxe como razões sustentadoras de seu entendimento, qual seja, o de reconhecimento de personalidade jurídica desde a concepção, embora de maneira condicional, os seguintes aspectos: a proteção ao ser humano pelo direito desde a concepção; o instituto da curadoria do nascituro; o reconhecimento de determinados direitos ao nascituro; e a possibilidade do reconhecimento de filhos naturais ainda por nascer. Mas conclui que:

qualquer que seja a opinião aceita sobre o início da personalidade do ser humano, o
nascimento é fato decisivo; no primeiro caso, porque confirma, se a criança nascer viva,
ou anula, se nascer morta, a personalidade atribuída ao nascituro; no segundo caso,
porque assinala o momento inicial da vida jurídica do homem. ${ }^{77}$

Nesse sentido, também podemos citar a opinião de Washington de Barros Monteiro, que parece perfilar de tal entendimento. Em poucas palavras, entende o autor que o nascituro é pessoa

\footnotetext{
${ }^{75}$ NERY JÚNIOR, Nelson; NERY, Rosa Maria de Andrade. Código Civil Comentado, p. 200.

${ }^{76}$ Artigo $2^{\circ}$ do Código Civil de 2002: “(...) mas a lei põe a salvo, desde a concepção, os direitos do nascituro” (grifos nossos).

${ }^{77}$ BEVILAQUA, Clóvis. Teoria Geral do Direito Civil, p. 97-101.
} 
condicional, sendo que a aquisição de personalidade depende da superveniência da condição suspensiva do nascimento com vida. ${ }^{78}$

O grande problema desta teoria reside no fato de ser a personalidade um direito absoluto e incondicional, não podendo, portanto, estar condicionada, como querem seus defensores.

Limongi França, adepto da doutrina concepcionista a ser estudada adiante, em crítica aos defensores das demais teorias atacou principalmente suas fundamentações. Dizia que estes doutrinadores dividiam-se em suas argumentações, ora defendendo estar o nascituro em situação jurídica idêntica à das pessoas jurídicas, ora referindo-se a um direito subjetivo sem titular concreto, ou, ainda, argumentando se tratar de um caso de personalidade condicional, o que contraria a lógica jurídica. Quanto aos defensores da teoria natalista, criticou ainda o fato de entenderem ser o nascituro spes hominis (esperança de pessoa) e não pessoa. ${ }^{79}$

Por fim, temos a chamada doutrina verdadeiramente concepcionista. Tem como seguidores Teixeira de Freitas, Rubens Limongi França, Anacleto de Oliveira Faria, André Franco Montoro, Silmara Juny de Abreu Chinellato, entre outros.

Para os concepcionistas, a personalidade é reconhecida desde a concepção, e não do nascimento com vida, sem qualquer condição. Consideram o nascituro pessoa, ou seja, sujeito de direitos, apenas condicionando ao nascimento com vida alguns efeitos de certos direitos patrimoniais. Essa teoria tem como grande vantagem o fato de conferir maior proteção à pessoa humana, tendência atual do Direito Civil, distanciando-se de uma visão anterior essencialmente patrimonialista.

Teixeira de Freitas, em seu Esboço, já sustentava o início da personalidade antes do nascimento, conforme demonstra no artigo 221: “Desde a concepção no ventre materno começa a existência visível das pessoas, e antes de seu nascimento elas podem adquirir alguns direitos, como se já estivessem nascidas”. O autor fundamenta essa posição em comentário a tal artigo sob os seguintes termos: "Não concebo (art. 16) que haja ente com suscetibilidade de adquirir direitos, sem que haja pessoa”. ${ }^{80}$ Mas foi apenas a partir de André Franco Montoro e Anacleto de

\footnotetext{
${ }^{78}$ MONTEIRO, Washington de Barros. Curso de Direito Civil, v. 1, p. 61.

${ }^{79}$ LIMONGI FRANÇA, Rubens. Manual de Direito Civil, v. 1, p. 143.

${ }^{80}$ TEIXEIRA DE FREITAS, Augusto. Esboço do Código Civil, p. 83-84.
} 
Oliveira Faria que a doutrina pátria contou com um primeiro estudo jurídico específico sobre o nascituro que defendesse sua existência como pessoa. ${ }^{81}$

Limongi França, trazendo alguns argumentos filosóficos, além de outros jurídicos, na defesa do nascituro como pessoa, assim aduziu:

\begin{abstract}
Filosoficamente, sem que nos seja necessário o apoio de toda uma corrente respeitabilíssima do pensamento humano (aristotélico-tomista), o nascituro é pessoa porque já traz em si o germe de todas as características do ser racional. A sua imaturidade não é essencialmente diversa da dos recém-nascidos, que nada sabem da vida e também não são capazes de se conduzir. O embrião está para a criança como a criança está para o adulto. Pertencem aos vários estágios do desenvolvimento de um mesmo ser: o Homem, a Pessoa. ${ }^{82}$
\end{abstract}

E sem deixar de lado a visão jurídica, entende que "quem diz direitos afirma capacidade. Quem afirma capacidade reconhece personalidade”. ${ }^{83}$

Maria Helena Diniz, por sua vez, traz a lume interessante classificação de personalidade jurídica, subdividindo-a em formal e material. A personalidade jurídica formal seria a correspondente àquela que atina aos direitos da personalidade e consideraria a existência do embrião desde a sua concepção. A personalidade jurídica material alcançaria os direitos patrimoniais e, esta sim, adquirir-se-ia somente com o nascimento com vida. ${ }^{84}$

Silmara Juny de Abreu Chinellato, ao comentar o antigo artigo $4^{\circ}$ do Código Civil de $1916,{ }^{85}$ traz que "a personalidade - que não se confunde com capacidade - não é condicional. Apenas certos efeitos de certos direito, isto é, os direitos patrimoniais materiais, como a herança e a doação, dependem do nascimento com vida", ${ }^{86}$

No que se refere a tal artigo, praticamente repetido pelo artigo $2^{\circ}$ do Código Civil atual, como se pode verificar, num primeiro momento nega a personalidade ao nascituro, mas num segundo momento parece acolher a ideia de que o nascituro tem personalidade jurídica. O que se tem afirmado entre os defensores da teoria concepcionista é que o legislador fez confusão entre

\footnotetext{
${ }^{81}$ MONTORO, André Franco; FARIA, Anacleto de Oliveira. Condição Jurídica do Nascituro no Direito Brasileiro. São Paulo: Saraiva, 1953.

${ }^{82}$ LIMONGI FRANÇA, Rubens. Manual de Direito Civil, v. 1, p. 144.

${ }^{83}$ Idem. Instituições de Direito Civil. 5. ed. São Paulo: Saraiva, 1999. p. 45.

${ }^{84}$ DINIZ, Maria Helena. Curso de Direito Civil Brasileiro, v. 1, p. 197.

${ }^{85}$ Artigo $4^{\circ}$ do Código Civil de 1916: "A personalidade civil do homem começa do nascimento com vida; mas a lei põe a salvo desde a concepção os direitos do nascituro”.

${ }^{86}$ CHINELLATO, Silmara Juny de Abreu. O nascituro no Código Civil e no Direito Constituendo do Brasil, p. 183.
} 
personalidade e capacidade, a qual se alastrou para parte da doutrina e da jurisprudência; no entanto, uma não se confunde com a outra. ${ }^{87}$

Personalidade é a aptidão para ser sujeito ou titular de direitos. E quem tem personalidade jurídica é considerado “pessoa”. Pessoa, portanto, “é o ser com personalidade jurídica, aptidão para a titularidade de direitos e deveres. Todo ser humano é pessoa pelo fato de nascer ou até de ser concebido". ${ }^{88}$ Aliada à ideia de personalidade está a de capacidade, mas ambas não se confundem. Capacidade é a maior ou menor extensão dos direitos da pessoa, é a aptidão para aquisição de direitos (capacidade de direito) e para o exercício, por si mesmo, de tais direitos (capacidade de fato). Todos os homens são pessoas, mas nem todos têm as mesmas capacidades.

Portanto, é a capacidade da pessoa que pode ser condicionada ao nascimento com vida e não a personalidade jurídica. Não se confunde capacidade com personalidade.

Francisco Amaral assevera:

\begin{abstract}
Nascimento é o fato, natural ou artificial, da separação do feto do ventre materno. Com a primeira respiração tem início o ciclo vital da pessoa, marcando, também, o nascimento, o início da capacidade de direito (...) o Código emprega o termo personalidade como sinônimo de capacidade de direito, o que é, a meu ver, superado. ${ }^{89}$
\end{abstract}

Nesse sentido, também, Limongi França entende ser o nascimento apenas condição para consolidação da capacidade jurídica e não da personalidade, que existe desde a concepção. ${ }^{90}$

Tal interpretação é dada levando-se em conta todo o sistema do Código Civil, que em muitos dispositivos arrola direitos do nascituro (artigos 542; 1.609; 1.779, parágrafo único; 1.798; etc.), sendo que, como visto, só pode ser titular de direitos quem detém a qualidade de pessoa. Ademais, o artigo $2^{\circ}$ do Código falar em “direitos do nascituro” deixaria claro, mais uma vez, que este tem personalidade jurídica, pois, como anteriormente afirmado, só é detentor de direitos quem a tem e o Código foi claro ao falar em "direitos” e não em "expectativa de direitos".

\footnotetext{
${ }^{87}$ Nesse sentido, cf. AMARAL, Francisco. Direito Civil: Introdução. Cf., também, CHINELLATO, Silmara Juny de Abreu. Tutela Civil do Nascituro.

${ }^{88}$ AMARAL, Francisco. Op. cit., p. 214.

${ }^{89}$ Ibidem, p. 217.

${ }^{90}$ LIMONGI FRANÇA, Rubens. Manual de Direito Civil, v. 1, p. 143.
} 
Nesse sentido, conforme asseveram André Franco Montoro e Anacleto de Oliveira Faria, “falar em direitos do nascituro é reconhecer-lhe qualidade de 'pessoa', porque, juridicamente, todo titular de direito é pessoa". 91

Resta importante assinalar que a tomada de posição de que o nascituro é pessoa importa reconhecer-lhe outros direitos que não apenas os elencados no Código Civil, podendo ser a ele atribuídos o direito à vida, à integridade física, à saúde, entre outros direitos da personalidade.

A tomada de posição dessa última linha doutrinária parece-nos estar mais de acordo com a defesa da pessoa humana; entendendo que o início da personalidade jurídica ocorre com a concepção e que o nascituro detém qualidade de pessoa, superado estará o primeiro problema, qual seja, o de garantir ao nascituro direito à indenização pelo dano a ele causado.

${ }^{91}$ MONTORO, André Franco; FARIA, Anacleto de Oliveira. Condição Jurídica do Nascituro no Direito Brasileiro, p. 10 . 


\section{O NASCITURO NO DIREITO ESTRANGEIRO}

A comparação do enfoque dos diferentes sistemas legais existentes no mundo sobre o tema revela-se de grande importância, já que para os estudos jurídicos a experiência alheia pode trazer um maior desenvolvimento do Direito nacional, ou, ao menos, levar a novas reflexões, enriquecendo a presente dissertação pela possibilidade de análise comparativa do tratamento dado ao nascituro no que diz respeito à sua qualidade de pessoa. Visamos, destarte, subsidiar o acréscimo de argumentos para defesa da reparação civil no caso de danos causado ao nascituro.

Atualmente é possível falar na existência de três grandes sistemas do Direito contemporâneo: a Common Law, notadamente presente na Inglaterra e nos Estados Unidos da América; o Sistema Soviético; e o Sistema Romano-Germânico, também conhecido por Civil Law, do qual fazem parte toda a Europa Continental, parte dos países da África, alguns países do Oriente próximo, como o Japão e a Indonésia, e a América Latina, incluindo o Brasil. ${ }^{92}$

Podemos afirmar que o Direito romano, posteriormente reafirmado pelo Código Civil francês de 1804, juntamente com o Código Civil alemão formou o sistema normativo romanogermânico tal como conhecemos e ao qual nos filiamos. Por isso, neste capítulo daremos atenção comparativa às principais legislações desse sistema do qual fazemos parte.

\subsection{França}

O Código Civil francês de 1804, conhecido também como Código Napoleônico, conseguiu sobreviver por mais de duzentos anos, restando ainda em vigor cerca de metade de seus artigos (1.200 dos 2.281 iniciais), dado o seu alto grau de aprimoramento técnico. Tendo sido considerado o primeiro Código moderno, tem uma importância histórica análoga à do

\footnotetext{
${ }^{92}$ FIUZA, César. Direito Civil: curso completo. 8. ed. Belo Horizonte: Del Rey, 2004. p. 27.
} 
Direito romano, que igualmente serviu de modelo para os posteriores códigos e leis dos países de origem romano-germânica. ${ }^{93}$

O Código Civil francês não regula de maneira expressa o início da personalidade jurídica, mas traz em seu corpo algumas normas referentes ao nascituro que servem de base às mais diferentes posições doutrinárias no tema. Para alguns, a análise dos artigos do Código como um todo levaria ao entendimento de que a personalidade jurídica do ser humano iniciar-se-ia a partir do nascimento com vida e com a comprovação de viabilidade. Para outros, no entanto, o nascimento com vida e a viabilidade seriam apenas condições de eficácia dos direitos, subsistindo ao nascituro a personalidade condicional. ${ }^{94} \mathrm{E}$ há ainda alguns autores franceses mais modernos, tal como Gérard Mémetau, os quais defendem, também com base na totalidade do sistema jurídico, a condição de pessoa do nascituro.

O artigo 725 do Código Civil francês traz a regra de que para ter o direito de herança o nascituro já teria que existir no momento da abertura da sucessão. Mas a personalidade completa, de forma que ele tenha capacidade para receber tal herança, se verifica com o nascimento com vida, observado o requisito da viabilidade.

O artigo 906 do Código Civil francês, por sua vez, ressalta que para o nascituro receber bens por doação, já teria que ter sido concebido quando do ato de doação inter vivos ou na época da declaração do testador. Acrescenta, ainda, ao final, que não obstante a doação e o testamento sejam realizados conforme a regra acima, estes atos somente terão efeitos se ele nascer com vida e for viável.

Tendo em vista tais artigos é que Vicente Ráo afirma que para o Direito francês a personalidade é atributo condicionado ao nascimento com vida e à viabilidade. ${ }^{95}$

Louis Sébag, doutrinador francês, analisando esses dois artigos, traça um princípio geral de que o nascituro só é sujeito de direitos sob a condição de nascer vivo e viável, embora entenda que o Código deixa certo, mesmo que de maneira implícita, que o nascituro é pessoa que existe. ${ }^{96}$

Para Gérard Mémetau, autor francês que se dedica ao estudo do tema do nascituro, os citados artigos, no entanto, se analisados em conjunto com toda a legislação francesa, afirmariam uma verdadeira qualidade humana do nascituro, uma vez que lhe é defendida a vida. O Código,

\footnotetext{
${ }^{93}$ RÁO, Vicente. O Direito e a vida dos direitos, p. 106.

${ }^{94}$ PUSSI, William Artur. Personalidade Jurídica do Nascituro. Curitiba: Juruá, 2006. p. 115-116.

${ }^{95}$ RÁO, Vicente. Op. cit., p. 652.

${ }^{96}$ SÉBAG, Louis. La condition juridique des personnes physiques et des personnes orales avant leur naissance. Paris: Sirey, 1938. p. 93 apud CHINELLATO, Silmara Juny de Abreu. Tutela Civil do Nascituro, p. 54.
} 
ao dispor que o testamento e a doação não surtem efeitos se o nascituro não nascer vivo e viável, não acarreta a ausência de direitos ao nascituro, mas apenas que a eficácia destes direitos estaria condicionada. $^{97}$

Assim, conforme este último entendimento, o nascimento com vida e a viabilidade seriam requisitos da eficácia de alguns direitos. E embora o Código Civil francês se refira aos direitos do nascituro apenas em alguns poucos artigos, a jurisprudência faz menção a outras hipóteses, tais como, a aquisição de nacionalidade, o reconhecimento da filiação e o direito a uma renda em caso de acidente de trabalho do genitor, ${ }^{98}$ complementando a ideia de que ao nascituro são conferidos direitos.

Embora exista esse posicionamento doutrinário mais protetor da qualidade de pessoa do nascituro, a legislação francesa ainda indica um outro caminho, o que não reconhece o status de pessoa ao nascituro. Como exemplo, a legislação complementar referente à interrupção da gravidez, que não pune o aborto provocado pela própria gestante ou por terceiros até determinado mês da gestação. ${ }^{99}$ Embora exista essa ressalva quanto à legislação francesa, é importante frisar que na doutrina há controvérsia nesse sentido, havendo quem defenda, como visto, uma interpretação legal em prol da condição de pessoa do nascituro.

Relacionado ao tema da responsabilidade civil por danos ao nascituro, também merece comento a situação recente que despontou na doutrina e na jurisprudência francesa acerca das chamadas ações de wrongful birth e wrongful life. São ações de responsabilidade civil pelo nascimento de uma criança com enfermidades, propostas pela própria criança nascida devidamente representada - ou por seus pais, contra os médicos, por estes não terem fornecido aos pais as informações necessárias sobre a gravidez, as quais teriam sido motivo de interrompêla, evitando assim o nascimento. A doutrina francesa, a Cour de Cassation e o Conseil d'État têm reconhecido a existência das ações de wrongful birth, concedendo indenização por danos patrimoniais e morais aos genitores da criança nascida com enfermidades. Relativamente às ações de wrongful life, que têm provocado maiores polêmicas, o primeiro caso a ser julgado na França, no qual a Corte francesa concedeu a indenização pelo simples fato de ter havido nascimento

\footnotetext{
${ }^{97}$ MÉMETAU, Gérard. La situation juridique de l'enfant conçu - de la rigueur classique à l'exaltation baroque. Revue Trimestrielle de Droit Civil, Paris, Sirey, n. 4, ano 89, p. 611-612, out./dez. 1990 apud CHINELLATO, Silmara Juny de Abreu. Tutela Civil do Nascituro, p. 62.

${ }_{98}^{98}$ CHINELLATO, Silmara Juny de Abreu. Tutela Civil do Nascituro, p. 60.

99 Disponível em: <www.legifrance.gouv.fr/affichTexte.do?cidTexte=LEGITEXT000006068506\&dateTexte=20090127>. Acesso em: 10 nov. 2009.
} 
(wrongful birth) foi o de Nicolas Perruche. Tal decisão gerou grande repercussão social, levando o Parlamento a editar a Lei n. 2001-303, de 04 de março de 2002, que veda a concessão de indenizações por danos ao filho pelo simples fato de ocorrer nascimento. ${ }^{100}$

\subsection{Itália}

O primeiro Livro do atual Código Civil Italiano de 1942 regulamenta a matéria da pessoa e da família. No âmbito da pessoa, disciplina separadamente a pessoa física da pessoa jurídica. Quanto à pessoa física, logo no artigo primeiro encontramos a seguinte disposição: “La capacità giuridica si acquista dal momento della nascita. I diritti che la legge riconosce a favore del concepito sono subordinati all'evento della nascita”. ${ }^{101}$

Num primeiro momento, podemos afirmar que a legislação italiana leva ao entendimento de que o ordenamento jurídico adota a teoria natalista, uma vez que diz em texto expresso que a personalidade jurídica se adquire com o nascimento com vida, bem como que os direitos que a lei reconhece ao concebido ficam subordinados ao nascimento com vida. ${ }^{102}$

Com base na literalidade do texto legal, poderíamos concluir que os requisitos naturais para o início da existência jurídica seriam dois: o nascimento e a vida. Vale ressaltar que, para esse sistema jurídico, a aquisição da capacidade jurídica, embora dependa do nascimento com vida, não exige o requisito de viabilidade, eis que a vida de poucos instantes, desde que autônoma, basta para que se obtenha a capacidade jurídica, com a qual o neonato torna-se titular de direitos, inclusive patrimoniais. ${ }^{103}$

No entanto, Pietro Perlingieri, em anotações ao Código Civil Italiano, aponta que parte da doutrina, com apoio na segunda parte do artigo $1^{\circ}$, sustenta a capacidade jurídica antecipada do

\footnotetext{
${ }^{100}$ MORILLO, Andrea Mácia. La responsabilidad médica por los diagnósticos preconceptivos y prenatales (las llamadas acciones de wrongful birth y wrongful life). Valencia: Tirant lo blanch, 2005. p. 129.

${ }^{101}$ PERLINGIERI, Pietro. Códice Civile Anotato com la dottrina e la giurisprudenza. Libro Primo: Delle persone e della famiglia. Napoli: Edizioni Scientifiche Italiane, 1991. p. 239.

${ }^{102}$ Vale destacar que o atual Código Civil italiano suprimiu o requisito da viabilidade, que antes era exigido como condição para aquisição de capacidade.

${ }^{103}$ Conforme observa Vicente Ráo, em O Direito e a Vida dos Direitos, os autores europeus utilizam a expressão “capacidade jurídica” no sentido de “personalidade”. RÁO, Vicente. O Direito e a Vida dos Direitos.
} 
nascituro, o que vem a demonstrar a divergência interpretativa quanto ao artigo $1^{\circ}$ na doutrina italiana. $^{104}$

Para Giovanni Iudica e Paolo Zatti, o Código Civil Italiano utiliza a expressão pessoa física para se referir ao ser humano. E eles aduzem que o legislador italiano, para indicar a qualidade de sujeito de direitos, usa da expressão “capacidade jurídica”, significando a propensão de ser titular de direitos e obrigações. Afirmam, nesse sentido, que a ideia de capacidade jurídica indica quando o homem é considerado como tal pelo Direito, e que, embora o Código não faça expressamente essa observação, hoje todo o ser humano igualmente a detém, desde o nascimento, sendo uma verdadeira prerrogativa constitucional do indivíduo. ${ }^{105}$

Francesco Gazzoni entende que adquirir capacidade jurídica significa passar a ser sujeito de direito e destinatário da norma elaborada no ordenamento jurídico em função substancialmente protetiva. Lembra que, historicamente, muitos ordenamentos criaram diversas categorias de indivíduos do ponto de vista jurídico, tal como o Direito romano em relação à escravidão ou o Direito canônico, que só atribuía capacidade jurídica após o batizado. O autor faz ainda, partindo de uma leitura da Carta Constitucional italiana, uma importante distinção entre a terminologia de sujeito de direito utilizada para o indivíduo e para o ente. Sustenta que somente ao último a capacidade jurídica seria fruto de uma discricionária valoração do ordenamento jurídico, já que os direitos invioláveis do homem não são atribuídos pelo ordenamento jurídico, mas sim reconhecidos como já existentes. Portanto, para o autor, o que se refere à pessoa e à capacidade jurídica não poderia ser uma atribuição do ordenamento, mas uma qualidade do próprio indivíduo. No entanto, no que se refere ao nascituro, apesar de reconhecer a existência da controvérsia, entende que ele é dotado de uma condição especial que o ordenamento leva em consideração, mas defende que os direitos a ele reconhecidos estão condicionados ao evento do nascimento. ${ }^{106}$

O entendimento sobre os direitos de caráter patrimonial no caso do nascituro, tais como o de suceder e de receber doações, não traz grandes discussões na doutrina italiana; a eficácia de tais direitos estaria subordinada ao nascimento. No caso de não ocorrer o nascimento com vida, considerar-se-iam os direitos como não havidos e, no caso de o nascimento se verificar, tornar-se-

\footnotetext{
${ }^{104}$ PERLINGIERI, Pietro. Códice Civile Annotato com la dottrina e la giurisprudenza, p. 242-243.

${ }^{105}$ IUDICA, Giovanni ; ZATTI, Paolo. Linguaggio e regole Del Diritto Privato. 6. ed. Padova: Cedam, 2005. p. 8384.

${ }^{106}$ GAZZONI, Francesco. Manuale di Diritto Privato. Napoli: Edizioni Scientifiche Italiane, 1994. p, 119-121.
} 
iam definitivos. O que tem sido fruto de muita discussão não só entre a doutrina italiana, mas também nos tribunais, refere-se à existência ou não de direitos da personalidade do nascituro. ${ }^{107}$

Mas quanto a esse tema, não basta a análise do Código Civil italiano, devendo ser analisada também outras legislações e a jurisprudência do país.

A Lei n. 194, de 22 de maio de 1978, que disciplina a interrupção da gravidez, em seu artigo $1^{\circ}$ protege a vida do feto. Inclusive, no caso de conflito entre a vida do feto e a saúde da mãe, discute-se o direito de ressarcimento do dano por lesão à integridade física do nascituro ocorrida durante a gravidez, como, por exemplo, num acidente de carro na estrada, ou no caso de transmissão de doença hereditária, má-formação devida ao uso de substâncias entorpecentes pela mãe durante a gravidez, entre outras situações. E quanto à responsabilidade de tratamento prénatal e à responsabilidade do médico, é consensual a opinião de que o feto deve ser tratado como um paciente, sendo representado por seus genitores. ${ }^{108}$

A Lei n. 40, de 19 de fevereiro de 2004, que traz normas em matéria de procriação medicamente assistida, também é fruto de algumas polêmicas, principalmente no que se refere aos embriões in vitro, para fins de procriação artificial ou para fins de pesquisa científica. A lei, que contém normas diversas de proteção do embrião, veda de modo absoluto qualquer experimentação em embriões humanos, consentindo a pesquisa clínica e experimental apenas para a finalidade de obter diagnósticos e terapias que representem vantagem direta ao embrião. Além disso, veda a formação de embrião para fins diversos da procriação assistida, a criopreservação e o descarte de embriões. ${ }^{109}$

Giovanni Iudica e Paolo Zatti entendem que a lei que trata da procriação medicamente assistida reconheceu subjetividade ao embrião, mas apenas em relação aos particulares direitos reconhecidos a ele. Também entendem que a lei que trata da interrupção da gravidez reconhece subjetividade ao feto. Mas em ambos os casos, ressaltam que não há que se confundir esse reconhecimento com a capacidade jurídica do artigo $1^{\circ}$ do Código Civil italiano. ${ }^{110}$

A fomentar a grande controvérsia existente na doutrina frente à legislação italiana, tivemos duas importantes decisões do Tribunal Constitucional da Itália. Em 18 de fevereiro de 1975, o Tribunal decidiu que a tutela do nascituro tem fundamento no artigo $2^{\circ}$ da Constituição

\footnotetext{
${ }^{107}$ IUDICA, Giovanni ; ZATTI, Paolo. Linguaggio e regole Del Diritto Privato, p. 85-86.

${ }^{108}$ Ibidem, p. 86.

${ }^{109}$ A Lei n. 40 de 19. 02. 2004 está disponível em: <www.parlamento.it/leggi/elelenum.htm>. Acesso em: 10 nov. 2009.

${ }^{110}$ IUDICA, Giovanni ; ZATTI, Paolo. Op. cit., p. 86.
} 
italiana, com interesses a serem protegidos, embora seus direitos dependam de expressa previsão legal. A outra sentença importante da Corte Constitucional foi a de n. 35, de fevereiro de 1997, na qual se declarou inadmissível o referendo proposto com o objetivo de ampliar as hipóteses de aborto legal, sob a fundamentação que a tutela do nascituro é prevista na Constituição e deve prevalecer o direito à vida. ${ }^{111}$

Acerca dessa rusga existente quanto ao reconhecimento ou não do nascituro como detentor de personalidade jurídica, ficamos com os dizeres de Pierangelo Catalano, que frente à aparente contradição entre o Código Civil e a Constituição Italiana, assinala que

a doutrina jurídica italiana, para a defesa dos nascituros, deve antes recorrer aos
princípios fixados na Constituição (art. 32, p. ex., que considera a saúde como
"fondamentale diritto dell’individuo") ou na "Declaração Universal dos Direitos do
Homem”, ou ainda na Declaração dos Direitos da Criança” das Nações Unidas. ${ }^{112}$

\subsection{Espanha}

O Código Civil espanhol, datado de 1889, sofreu grande influência do Direito romano, bem como do Código Civil francês. Mas o Direito espanhol, ao contrário do francês, não realizou a unificação do Direito Civil, estando ainda em vigor as legislações faroleiras. ${ }^{113}$

Na análise da legislação espanhola, principalmente dos artigos 29 e 30 do Código Civil, podemos extrair, em princípio, que não se reconhece personalidade jurídica ao nascituro.

A legislação espanhola, no entanto, conforme o autor espanhol Manuel Albaladejo, não exige apenas o nascimento com vida para aquisição da personalidade jurídica e o reconhecimento da pessoa como tal para o mundo jurídico. Necessárias também são a forma humana e a viabilidade. ${ }^{114}$ Este último requisito, o da viabilidade, se baseia num critério meramente legal, qual seja, o do decorrer de 24 horas após o nascimento. ${ }^{115}$

\footnotetext{
${ }^{111}$ As decisões da Corte Constitucional da Itália estão disponíveis em: <www.cortecostituzionale.it>. Acesso em: 10 nov. 2009.

${ }^{112}$ CATALANO, Pierangelo. Os nascituros entre o Direito Romano e o Direito latino-americano, p. 12.

${ }^{113}$ RÁO, Vicente. O Direito e a vida dos direitos, p. 108.

114 ALBALADEJO, Manuel. Derecho Civil I: introducción y parte general. v. 1 - introducción y derecho de la persona. 4. ed. Barcelona: Bosch, 1975. p. 185.

${ }^{115}$ Tal exigência se dá, em grande parte, por inspiração do Direito romano, que tinha por finalidade evitar a transmissão de bens e direitos em casos de recém-nascidos que morrem poucas horas depois de seu nascimento.
} 
No exame dos artigos 29 e 30 do Código Civil espanhol, verificamos, conforme já afirmado, que o nascimento com forma humana e a viabilidade determinam a personalidade. No entanto, resta acrescentar que a pessoa nascida terá todos os efeitos de seus direitos tidos como existentes desde o momento da concepção. ${ }^{116}$ Mas, embora a lei confira ao nascituro tutela jurídica e lhe reconheça uma série de (expectativas de) direitos, ao ver de alguns doutrinadores, tais como Manuel Albaladejo, assim o faz apenas por considerar o nascituro um bem jurídico necessitado de tutela, mas não por considerá-lo pessoa. Conforme este entendimento, portanto, é negada personalidade jurídica ao nascituro e ao recém-nascido nas suas primeiras 24 horas de vida, o que parece se justificar por questões meramente patrimoniais.

Conforme Luis Díez Picazo y Antonio Gullón: “En realidad, la protección al concebido se sustancia em uma afección de los bienes y derechos a él atribuibles cuando nazca a unas medidas de protección para que, mientras, no se destruyan o pierdan”. ${ }^{117}$

Ao nosso ver, o legislador espanhol, ao pensar apenas na questão patrimonial deixa sem proteção os direitos da personalidade do nascituro e do já nascido com menos de 24 horas de vida, desqualificando-os como pessoa, o que não se coaduna com o princípio universal da dignidade da pessoa humana, nem com o da igualdade.

Nesse sentido, a interpretação dada ao Código Civil espanhol não pode se basear apenas nos artigos 29 e 30, devendo ser observado todo o sistema jurídico espanhol. Sob este aspecto, Silmara Juny de Abreu Chinellato aponta que o artigo 964 do Código Civil espanhol, ${ }^{118}$ ao determinar que a viúva, ainda que com condições financeiras suficientes, seja alimentada com os bens hereditários considerando a parte que neles terá direito o nascituro se nascer com vida e viável, estaria a assegurar os meios para o desenvolvimento do nascituro, consagrando-lhe o direito à vida, visando ao nascimento, mas dele, em realidade, independendo. ${ }^{119}$

\footnotetext{
${ }^{116}$ Assim preceituam os artigos 29 e 30 do Código Civil espanhol: Artigo 29 do CC: "El nacimiento determina la personalidad: pero el concebido se tiene por nacido por todos los efectos que le sean favorables, siempre que nazca con las condiciones que expresa el artículo siguiente". Artigo 30: "Para los efectos civiles, sólo se reputará nacido el feto que tuviere figura humana y viviere veinticuatro horas enteramente desprendido del seno materno". Disponível em: <http://civil.udg.edu/normacivil/estatal/CC/1T2.htm>. Acesso em: 10 nov. 2009.

${ }^{117}$ PICAZO, Luis Díez; GULLÓN, Antonio. Instituiciones de derecho civil. v. 1. 2. ed. Madrid: Tecnos, 2000. p. 129.

118 "Artículo 964. La viuda que quede encinta, aun cuando sea rica, deberá ser alimentada de los bienes hereditários, habida consideración a la parte que em ellos pueda tener el póstumo, si naciere y fuere viable”. (Codigo Civil Espanhol).

${ }^{119}$ CHINELLATO, Silmara Juny de Abreu. Tutela Civil do Nascituro, p. 77.
} 
Podemos ainda apontar outros direitos conferidos ao nascituro pelo Código Civil Espanhol, tais como o direito de receber doação (art. 627) ou a possibilidade de nomeação de um administrador de bens hereditários ao nascituro (arts. 957 a 967).

Por fim, também podemos nos referir às ações de wrongful birth, de aparição recente nos tribunais superiores espanhóis. ${ }^{120}$ A doutrina majoritária no país tem se inclinado pela admissão de tais ações. Mas tanto nos tribunais, como na doutrina, ainda não há um consenso quanto aos fundamentos da responsabilidade e quanto a forma de fixação da indenização. ${ }^{121}$

\subsection{Portugal}

As primeiras fontes jurídicas do direito português foram o Corpus Iuris Civilis e as glossas do Direito romano, bem como as Decretais de Gregório IX, do Direito canônico. ${ }^{122}$ A partir do século $\mathrm{XV}$, foram elaboradas as primeiras legislações portuguesas, traduzidas pelas Ordenações. E apenas em 1967 tivemos o primeiro Código Civil português, o chamado Código Seabra, que reviveu e adotou o Direito romano e sofreu grande influência do Código Napoleônico e do Código Civil espanhol. Tal Código sofreu alterações, em 1977, para melhor se adaptar à Constituição portuguesa, que data de 1976.

A antiga redação do Código Civil português, de 1967, no artigo $6^{\circ}$ combinado com os artigos 110, 1.479 e 1.776, exigia para o início da personalidade o nascimento com vida e a forma humana. Isso indica que vigia a teoria natalista da personalidade no sistema jurídico português. ${ }^{123}$

No entanto, José Tavares já questionava se não devia se atribuir personalidade jurídica desde a concepção

\footnotetext{
Não hesitaríamos até em atribuir à concepção, em vez do nascimento, a origem da personalidade humana. É que a personalidade ou capacidade jurídica, como qualidade inata do indivíduo humano, só se concebe como atributo inerente ao próprio ser, como uma conseqüência imediata da formação e existência do organismo do indivíduo. Ora

${ }^{120}$ A primeira decisão envolvendo wrongful birth remonta à sentença do Tribunal Superior de 06 de junho de 1997.

${ }^{121}$ MORILLO, Andrea Mácia. La responsabilidad médica por los diagnósticos preconceptivos y prenatales (las llamadas acciones de wrongful birth y wrongful life), p. 140-142.

${ }^{122}$ RÁO, Vicente. O Direito e a vida dos direitos, p. 109.

123 TAVARES, José. Os princípios fundamentais do Direito Civil. v. 2. Coimbra: Coimbra Editora, 1928. p. 21.
} 
êste ser, êste organismo, forma-se pelo fenômeno biológico da concepção, começa a existir, a viver, e a desenvolver-se desde êsse momento; desde então começa a ser protegido pela lei para diversos efeitos jurídicos (art. $6^{\circ}, 157^{\circ}, 1479^{\circ}, 1776^{\circ} \ldots$. ); e por isso desde logo deveria ser reconhecida a sua personalidade. ${ }^{124}$

A legislação portuguesa atual, embora ainda esteja sob influência da teoria natalista, diferencia-se da anterior, pois não mais exige a forma humana para o reconhecimento da personalidade, sendo necessário apenas o nascimento com vida. Assim preceitua o atual Código Civil, Decreto-lei 47.344 de 1966 com as alterações de 1977, em seu artigo 66, sob o título de começo da personalidade: “1 - a personalidade adquire-se no momento do nascimento completo e com vida. 2 - os direitos que a lei reconhece aos nascituros dependem de seu nascimento”. ${ }^{125}$

Mas, embora a redação legal, o Código Civil português traz alguns direitos do nascituro, embora condicionados na sua eficácia ao nascimento com vida. Estão entre eles o direito de receber doações (artigo 952), o de ser incluído na sucessão legal e testamentária (artigo 2.033º n. 1), o de ter reconhecida sua filiação (artigos $1.847^{\circ}, 1.854^{\circ}, 1.855^{\circ}$ ) e o de ser abrangido pelo poder paternal (artigo $1.878^{\circ}$ ). Isso abre portas, de acordo com Mota Pinto, para a discussão doutrinária sobre a possibilidade de o nascituro ser considerado sujeito de direitos. ${ }^{126}$

Nesse sentido, autores como Rabindranath Capelo de Sousa, Mario Bigotte Chorão e Diogo Leite de Campos, entendem ser o nascituro detentor de direitos da personalidade e, portanto, deter a natureza jurídica de pessoa.

Ainda, a Constituição de Portugal, em seu artigo 24, traz a vida humana como um bem inviolável. Em comentário a este artigo, J. J. Gomes Canotilho e Vital Moreira entendem que a Constituição ao garantir proteção à vida humana o faz abrangendo também a vida pré-natal. ${ }^{127}$

Quanto à jurisprudência portuguesa, em que pesem as decisões apontando para o entendimento de que o nascituro não tem personalidade jurídica, sendo esta apenas adquirida com o nascimento com vida, já se verificam mudanças, demonstrando uma possível modificação jurisprudencial. Inclusive, uma recente decisão da Suprema Corte de Portugal levou a tal entendimento, conforme se verifica pelo voto vencido do Ministro Mário Cruz no processo de número 08A2124, julgado em 17 de fevereiro de $2009 .{ }^{128} \mathrm{O}$ voto indica se não uma possível

\footnotetext{
${ }^{124}$ TAVARES, José. Os princípios fundamentais do Direito Civil, v. 2, p. 12.

${ }^{125}$ LIMA, Fernando Andrade Pires de; VARELA, João de Matos Antunes. Código Civil Anotado. v. 1. 4. ed. Coimbra: Coimbra Editora, 1987. p. 101.

${ }^{126}$ PINTO, Carlos Alberto da Mota. Teoria Geral do Direito Civil. 3. ed. Coimbra: Coimbra Editora, 1999. p. 200.

${ }^{127}$ CANOTILHO, J. J. Gomes. Constituição da República Portuguesa Anotada. 3. ed. Coimbra: Coimbra Editora, 1993. p. 175.

${ }^{128} \mathrm{O}$ acórdão e o voto vencido estão disponíveis em: <www.stj.pt>. Acesso em: 11 out. 2009.
} 
mudança jurisprudencial, ao menos um fundamento importante em prol da tutela do nascituro como sujeito de direitos, e merece referência face à exposição detalhada dos direitos do nascituro na legislação portuguesa e face ao raciocínio lógico, pois tal levou o magistrado a adotar posição diametralmente oposta à do voto vencedor, reconhecendo a possibilidade de o nascituro receber indenização por dano não patrimonial por direito próprio.

\subsection{Argentina}

O Código Civil argentino, que teve sua redação fortemente influenciada pelo Esboço de Teixeira de Freitas, explicita que a concepção, isto é, o princípio da vida intrauterina, é o marco inicial da personalidade. Nesse sentido, aduz o artigo 70 do atual Código argentino:

Desde la concepción en el seno materno comienza la existencia de las personas; y antes de su nacimiento pueden adquirir algunos derechos, como si ya hubiesen nacido. Esos derechos quedan irrevocablemente adquiridos si los concebidos en el seno materno nacieren con vida, aunque fuera por instantes después de estar separados de su madre. ${ }^{129}$

Em observação ao Código Civil argentino e ao seus artigos, em especial o artigo 70, Silmara Juny de Abreu Chinellato conclui que tal Código consagra a teoria concepcionista. ${ }^{130}$

${ }^{129}$ Disponível em: <www.redetel.gov.ar/Normativa/Archivos\%20de\%20Normas/CodigoCivil.htm>. Acesso em: 10 nov. 2009.

${ }^{130}$ CHINELLATO, Silmara Juny de Abreu. Tutela civil do nascituro, p. 87. 


\section{O NASCITURO PERANTE O ORDENAMENTO JURÍDICO BRASILEIRO}

\subsection{Constituição da República Federativa do Brasil de 1988}

A atual Constituição brasileira, fruto do retorno da democracia e inspirada nos ideários pós-Guerras de respeito ao ser humano e de paz entre as nações, além de trazer a organização da sociedade política, esboçou em seu corpo importante proteção aos direitos fundamentais.

As garantias trazidas pela Constituição se refletem em todo sistema jurídico. Seus princípios se irradiam sobre todas as normas infraconstitucionais. E a interpretação jurídica das normas civilistas deve ser feita com base numa interpretação constitucional. Nesse sentido, Luís Roberto Barroso sustenta que toda interpretação jurídica é também uma interpretação constitucional no aspecto da compatibilidade da regra jurídica para com as normas constitucionais e no aspecto de filtragem. ${ }^{131}$ Portanto, a interpretação da legislação ordinária, em especial o Direito Civil, deve ser feita à luz da Constituição.

Mas em que sentido a Constituição se relaciona ao nascituro?

Falar de nascituro é tratar de forma direta do tema da vida humana. O direito à vida é direito de suma importância e é garantido não só por nossa Constituição Federal, mas também por diversos tratados internacionais. Não é exagero afirmar que é a vida um dos maiores bens do ser humano, sem o qual o mesmo sequer existe.

O direito à vida vem previsto no caput do artigo $5^{\circ}$ da Constituição Federal, que é o primeiro artigo a tratar dos direitos individuais fundamentais. E, como direito fundamental, é um “pressuposto elementar de todos os demais direitos e liberdades dispostos na Constituição”, 132 já que dos direitos fundamentais se extrai a estrutura básica dos demais direitos. A proteção à vida humana é tão importante que se reflete em todos os ramos do Direito, protegendo-se não só a vida enquanto "existência", mas também enquanto qualidade de vida. Portanto, ao tratar do

131 BARROSO, Luís Roberto. Interpretação e Aplicação da Constituição: fundamentos de uma dogmática constitucional transformadora. 6. ed. São Paulo: Saraiva, 2008.

${ }_{132}$ MENDES, Gilmar Ferreira; COELHO, Inocêncio Mártires; BRANCO, Paulo Gustavo Gonet. Curso de Direito Constitucional. 4. ed. rev. e atual. São Paulo: Saraiva, 2009. p. 393. 
direito à vida, devemos nos ater às suas duas facetas: o direito de permanecer vivo ou não ser morto e o direito de viver com dignidade.

O direito de permanecer vivo ou não ser morto é extraído do próprio texto Constitucional, seja quando a Constituição garante o direito à vida em sentido amplo ( $5^{\circ}$ caput), seja quando proíbe a pena de morte (5, XLVII, “a”), ou quando reconhece à instituição do Júri a competência para julgamento dos crimes dolosos contra a vida.

Tendo em vista que a Constituição não diferencia o nascituro e o já nascido, e no caput do artigo $5^{\circ}$ estabelece que “todos” têm direito à vida. Há, portanto, de se considerar que a Constituição Federal protege o direito à vida também ao nascituro. ${ }^{133}$

Essa é a posição de Silmara Chinellato, que defende que da análise sistemática da Constituição pode se extrair que ela não admite o aborto, protegendo o direito à vida do nascituro:

\begin{abstract}
O inciso XXXVIII do art. $5^{\circ}$ reconhece a instituição do Júri, com competência pra julgamento dos crimes dolosos contra a vida, entre eles o aborto. Assegura, ainda, a licença-gestante, com duração de cento e vinte dias (art. $6^{\circ}$, XVII, a), a proteção à maternidade, especificamente à gestante (arts. 201,II, e 203, I), com a finalidade de proteger a mãe e o nascituro. ${ }^{134}$
\end{abstract}

Paulo Gustavo Gonet Branco entende que: “o direito à vida cola-se ao ser humano, desde que este surge e até o momento da sua morte”. ${ }^{135}$ Concluímos, portanto, que a todo ser humano, incluído aqui o nascituro, deve ser assegurado o direito mais elementar que é o de existir, uma vez que sem ele nem há que se falar em outros direitos.

Cabe destacar ainda que, recentemente, o direito à vida obteve grande destaque quando da discussão da constitucionalidade do artigo $5^{\circ}$ da Lei de Biossegurança. Tal artigo trouxe a possibilidade de, para fins de pesquisa e terapia, serem utilizadas células-tronco obtidas de embriões humanos produzidos por fertilização in vitro e não usados no respectivo procedimento, estabelecendo condições para essa utilização. ${ }^{136}$ Colocaram-se em pauta na sociedade duas

\footnotetext{
${ }^{133}$ No entanto, como todos os direitos, o direito à vida não é um direito absoluto, podendo ser excepcionado pela própria Constituição (como no caso de pena de morte por fuzilamento em estado de guerra, e pena de morte no estado de sítio por motivo de guerra).

${ }^{134}$ CHINELLATO, Silmara Juny de Abreu. Tutela Civil do nascituro, p. 247.

135 MENDES, Gilmar Ferreira; COELHO, Inocêncio Mártires; BRANCO, Paulo Gustavo Gonet. Curso de Direito Constitucional, p. 395.

${ }^{136}$ Embora o Supremo Tribunal Federal, em 2008, tenha decidido pela constitucionalidade da Lei de Biossegurança, sob os argumentos de que a "vida humana já revestida do atributo da personalidade civil é o fenômeno que transcorre entre o nascimento com vida e a morte" (Carlos Ayres Britto, relator), e de que "o pré-embrião não acolhido no seu ninho natural de desenvolvimento, o útero, não se classifica como pessoa” (Ellen Gracie), não foi esta a posição
} 
discussões: a do início da vida e a de sua harmonização com outros direitos fundamentais que com ela conflitem no caso concreto, como, por exemplo, o direito à saúde. ${ }^{137}$

Embora a decisão do Supremo Tribunal Federal tenha sido, por maioria, pela constitucionalidade da Lei federal n. 11.105/2005 (Lei da Biossegurança), tal decisão não fez referência direta ao momento inicial da vida humana, admitindo somente a pesquisa em embriões humanos considerados não viáveis, conforme os requisitos legais. A decisão do STF apenas compatibilizou a possibilidade de desenvolvimento com o respeito ao embrião pré-implantatório, conciliando desenvolvimento e dignidade.

E, como dito anteriormente, embora o presente trabalho se cinja ao estudo do nascituro já concebido no ventre materno, a discussão travada no Supremo Tribunal Federal foi de grande importância para reavivar questões jurídicas de cunho bioético que haviam sido relegadas ao esquecimento, dando oportunidade para a ciência do Direito repensar suas doutrinas com base nos novos ditames e descobertas científicas sobre a vida e o desenvolvimento humano.

Quanto ao direito à vida em sua segunda acepção, temos que o direito à vida com dignidade é expressão do fundamento maior da República Federativa do Brasil, qual seja, a dignidade da pessoa humana. Nesse sentido, cabe lembrar que a dignidade humana é, antes de tudo, um valor espiritual inerente à condição humana que, inclusive, nos diferencia dos outros seres viventes.

Conforme lição de Antonio Junqueira de Azevedo, tendo-se em vista uma concepção ética, a dignidade da pessoa humana não deve ser entendida como autodeterminação, mas sim como qualidade do ser vivo. ${ }^{138}$

A dignidade é inerente à condição de homem, não é a lei que define a dignidade, ela existe independentemente de lei que a preveja. É garantida a todos os seres humanos igualmente, sem distinções. Tamanha é sua importância que está prevista logo no artigo $1^{\circ}$ da Constituição Federal, sendo considerada fundamento da República Federativa do Brasil.

unânime da Corte. Alguns Ministros exararam opinião no sentido de que "o embrião é desde a fecundação um indivíduo, um representante da espécie humana com toda a carga genética do feto" (Carlos Alberto Menezes Direito), e de que "o embrião - insisto neste ponto - faz parte do gênero humano, já é uma parcela de humanidade" (Eros Grau). Cf. Folha de São Paulo, p. A15, 30 maio 2008. Mas nosso trabalho destina-se ao ser já concebido no ventre materno. Devendo, a ele, nos atermos.

${ }^{137}$ MENDES, Gilmar Ferreira; COELHO, Inocêncio Mártires; BRANCO, Paulo Gustavo Gonet. Curso de Direito Constitucional, p. 394-395.

${ }^{138}$ AZEVEDO, Antonio Junqueira de. Caracterização jurídica da dignidade da pessoa humana. Revista Trimestral de Direito Civil, v. 9, jan./mar. 2002, p. 5. 
Fábio Konder Comparato, referindo-se à Declaração Universal dos Direitos do Homem, a qual explicita que "todos os homens nascem livres e iguais em dignidade e direitos", afirma que todas as pessoas devem ser igualmente respeitadas, simplesmente por sua humanidade. ${ }^{139} \mathrm{E}$ é exatamente nesse sentido que o tema se liga ao nascituro, uma vez que, tendo em vista sua natureza humana, deve ele ser respeitado em sua dignidade simplesmente por sua humanidade, cabendo-lhe todas as proteções jurídicas nesse sentido.

Nesse ponto, de modo a sustentar com maior precisão a importância da conquista da garantia do direito à vida em seu duplo aspecto, ressaltando-a como valor supremo na ordem constitucional, cabe uma breve reflexão sobre as características dos direitos humanos e dos direitos fundamentais. Os direitos humanos abrangem os direitos mínimos do homem, os direitos a ele inerentes, cuja finalidade básica é o respeito à sua dignidade. Eles têm como uma de suas características sua historicidade, ou seja, eles advêm da história do homem. É da natureza do homem lutar pela conquista de direitos em prol de sua espécie. Quando positivados, são chamados de direitos fundamentais.

A nossa Constituição elencou extensa lista de direitos fundamentais, sendo que no caput do artigo $5^{\circ}$ proclamou os cincos valores básicos que inspiram o rol dos direitos fundamentais constitucionais: a vida, a liberdade, a igualdade, a segurança e a propriedade, assim preceituando: “Todos são iguais perante a lei, sem distinção de qualquer natureza, garantindo-se aos brasileiros e aos estrangeiros residentes no País a inviolabilidade do direito à vida, à liberdade, à igualdade, à segurança e à propriedade". ${ }^{140}$

Embora a Constituição não determine expressamente o momento inicial de proteção da vida humana, ${ }^{141}$ é importante ressalvar que toda norma de direito fundamental deve ser interpretada extensivamente, de modo que lhe seja conferida máxima efetividade. ${ }^{142}$ Portanto, o nascituro, num primeiro momento, à luz da Constituição Federal e de acordo com regras interpretativas dos princípios constitucionais, deve ter sua vida protegida pelo Estado, não cabendo ao legislador infraconstitucional restringir o sentido da norma constitucional.

\footnotetext{
${ }^{139}$ COMPARATO, Fábio Konder. A afirmação histórica dos direitos humanos, p. 18.

${ }^{140}$ Grifos nossos.

${ }^{141}$ Silmara Juny de Abreu Chinellato, em O nascituro no Código Civil e no Direito Constituendo, atenta para o fato de que nos diversos anteprojetos que antecederam o texto final da Constituição vigente foi travada discussão no sentido de consagrar expressamente proteção jurídica desde a concepção ou de fazê-lo apenas a partir do nascimento com vida, prevalecendo, por fim, a proteção genérica ao direito à vida, não adentrando a Constituição na questão. CHINELLATO, Silmara Juny de Abreu. O nascituro no Código Civil e no Direito Constituendo, p. 180-7.

${ }_{142}$ Podemos verificar em julgado recente do Superior Tribunal de Justiça que expressamente foi reconhecido o direito à vida do nascituro, cf. Ag. Reg. no REsp n. 104.5750/RS.
} 
Não é outro o entendimento de Paulo Gustavo Gonet Branco, o qual aduz que "o direito à vida não pode ter o seu núcleo essencial apequenado pelo legislador infraconstitucional”. Se analisássemos o direito à vida garantido constitucionalmente conforme a legislação ordinária, mais propriamente como constante da $1^{\text {a }}$ parte do artigo $2^{\circ}$ do Código Civil, faríamos uma interpretação restritiva inadequada de tal direito. Máxime porque a interpretação não se faz da legislação ordinária para a Constituição, mas sim em sentido contrário, da Constituição para a legislação ordinária, devendo-se, nesse entrementes, respeitar os tratados de direitos humanos, de forma a conferir a garantia ampla prevista na norma constitucional de respeito ao direito à vida.

Ainda, servindo-nos de outros princípios constitucionais, podemos fazer referência também ao princípio da igualdade. Desrespeitar o direito à existência do ser humano, dosar quem tem mais ou menos direito à vida ou condicioná-lo a aspectos acidentais que marcam a existência de cada pessoa seria ferir não só a dignidade humana, mas também a igualdade, valor também positivado como princípio em nossa Constituição Federal. Nas palavras de Paulo Gustavo Gonet Branco, "nem a origem étnica, nem a origem geográfica, nem as opções de comportamento, nem a idade - nada justifica que se aliene de um ser humano o direito à vida”. ${ }^{143}$

Conforme preleciona Celso Antônio Bandeira de Mello, para que um discrímen legal conviva com a isonomia, devem ser observados alguns critérios, entre eles: "que as situações ou pessoas desequiparadas pela regra de direito sejam efetivamente distintas entre si”; "que exista, em abstrato, uma correlação lógica entre os fatores diferenciais existentes e a distinção de regime jurídico em função deles, estabelecida pela norma jurídica”, além de que “in concreto, o vínculo de correlação supra-referido seja pertinente em função dos interesses constitucionalmente protegidos”, ${ }^{144}$ o que não se justifica no caso do nascituro face ao já nascido.

Portanto, para serem conferidos ao recém-nascido direitos que não o sejam ao nascituro, deve existir uma situação distinta entre eles, e mais, deve existir, em abstrato, uma relação lógica entre os fatores de discrímen estabelecidos pela norma e fundamentados nos interesses constitucionais. Ora, mesmo que entendêssemos ser diferente a situação do nascituro da de um recém-nascido, haveríamos que seguir o princípio constitucional de proteção dos mais indefesos e de dignidade da pessoa humana, jamais considerando que tolher a personalidade do nascituro,

\footnotetext{
${ }^{143}$ MENDES, Gilmar Ferreira; COELHO, Inocêncio Mártires; BRANCO, Paulo Gustavo Gonet. Curso de Direito Constitucional, p. 396.

${ }^{144}$ MELLO, Celso A. B. Conteúdo Jurídico do Princípio da Igualdade. 3. ed. São Paulo: Malheiros, 2009. p. 41.
} 
não lhe conferindo proteção aos seus direitos de personalidade, seria razoável ou justificável à luz da Constituição.

Nesse sentido, Diogo Leite de Campos, assim aduz:

Desde logo, por a distinção, para efeitos jurídicos, entre o "nascituro" (pessoa humana ainda não nascida) e pessoa humana já nascida ("morituro"?) viola o direito à igualdade (...) O nascimento, já afirmamos, nada significa. Só a substituição de um sistema de apoio à vida (o corpo da mãe) por outro (o meio ambiente e os pais). ${ }^{145}$

De acordo com o conhecimento atual sobre a gestação, é inevitável concluirmos que a vida de relação existe já no ventre da mãe e que a autonomia de um recém-nascido com poucos dias de vida em nada é maior do que a do que está por nascer. Ademais, atualmente, é possível afirmar que a vida intrauterina é tão conhecida e incerta quanto a vida extrauterina, pondo por terra qualquer argumento relativo à viabilidade.

Aceitar tratamento diferenciado ao nascituro, não reconhecendo sua personalidade e reduzindo-o a um conceito menos abrangente do que o de pessoa, seria, por todos os argumentos expostos, uma ofensa à igualdade conferida a todos os seres humanos pela Constituição Federal.

Do exposto, chegamos à conclusão de que o direito fundamental à vida previsto constitucionalmente, se analisado sob uma interpretação extensiva e fundada nos princípios da dignidade humana e da igualdade, abarca tanto a pessoa já nascida como o ser já concebido no ventre materno, sem diferenciação.

\subsection{Tratados e Convenções Internacionais}

Os tratados internacionais, de uma maneira geral, são acordos formais, concluídos entre os sujeitos de Direito Internacional Público e destinados a produzir efeitos jurídicos na órbita internacional. Quando um tratado é internalizado no ordenamento jurídico, este adquire força normativa interna e, aí, surge a questão acerca da natureza jurídica dessa norma.

No Brasil, vislumbramos um regime misto para os tratados internacionais: um é aplicado em tratados que não versem sobre direitos humanos e outro em tratados que versem sobre direitos

\footnotetext{
${ }^{145}$ CAMPOS, Diogo Leite de. A capacidade sucessória do nascituro (ou a crise do positivismo legalista), p. 52.
} 
humanos. Quanto ao primeiro, há unanimidade na doutrina em considerar que eles se incorporam ao ordenamento pátrio com força de lei ordinária. Caso se trate de um tratado internacional que versa sobre direitos humanos, não há consenso doutrinário quanto à sua natureza jurídica.

Após a Constituição de 1988, mas antes da Emenda Constitucional n. 45 de 2004, foram constatadas quatro posições acerca do tema, tendo em vista o parágrafo $2^{\circ}$ do artigo $5^{\circ}$ da Constituição Federal, que trata do alcance dos direitos fundamentais e traz a seguinte redação: “Os direitos e garantias expressos nesta Constituição não excluem outros decorrentes do regime e dos princípios por ela adotados, ou dos tratados internacionais em que a República Federativa do Brasil seja parte”. ${ }^{146}$

Uma primeira posição, considerada tradicional, argumentava que os tratados internacionais de direitos humanos, assim como quaisquer outros, incorporar-se-iam ao ordenamento pátrio com natureza de lei federal. ${ }^{147}$ Uma segunda posição, por outro lado, sustentava que seriam incorporados com status de norma infraconstitucional, porém supralegal. Ainda uma terceira corrente, defendida por Antônio Augusto Cançado Trindade, Flávia Piovesan, entre outros, defendia que por força do parágrafo $2^{\circ}$ do artigo $5^{\circ}$ da $\mathrm{CF}$, tais tratados seriam incorporados ao ordenamento jurídico com hierarquia constitucional. Por fim, podemos citar uma tese mais extremista desposada, por exemplo, por Augustín Gordillo, que os entendia internalizados com status supraconstitucional.

Com a Emenda Constitucional n. 45/04 foi elaborado novo parágrafo ao artigo 5º de forma a tentar pacificar as discussões quanto à natureza dos tratados internacionais de direitos humanos a serem incorporados ao nosso ordenamento jurídico, uma vez que os equiparou às Emendas Constitucionais no caso de serem ratificados sob determinada forma. ${ }^{148}$ No entanto, não foi solucionada a questão de direito intertemporal no que se refere aos tratados já incorporados ao ordenamento anteriormente a tal Emenda.

Podemos verificar, atualmente, a existência de duas correntes principais: uma que defende a natureza constitucional de tais tratados e outra que defende sua natureza infraconstitucional, porém supralegal.

\footnotetext{
${ }^{146}$ Grifos nossos.

${ }^{147}$ Essa foi, inclusive, a posição sustentada pelo Supremo Tribunal Federal num primeiro momento, conforme podemos verificar no RHC 79.785, julgado em 2002, cujo relator foi o Ministro Sepúlveda Pertence.

${ }_{148}$ Artigo $5^{\circ}$, $\S 3^{\circ}$, da Constituição Federal: "Os tratados e convenções internacionais sobre direitos humanos que forem aprovados, em cada Casa do Congresso Nacional, em dois turnos, por três quintos dos votos dos respectivos membros, serão equivalentes às emendas constitucionais”.
} 
Flávia Piovesan pode ser citada como defensora da primeira posição, entendendo serem os tratados internacionais de direitos humanos materialmente constitucionais, por força do citado parágrafo $2^{\circ}$ do artigo $5^{\circ}$, independentemente do momento de sua incorporação, alegando que a mudança do aludido artigo $5^{\circ}$ da Constituição Federal, relativa ao acréscimo do parágrafo $3^{\circ}$, apenas possibilitou o reconhecimento dos tratados que versem sobre direitos humanos como normas formalmente constitucionais. Tal argumento é sustentado até mesmo porque na época em que foram incorporados ao sistema normativo interno não havia essa exigência constitucional quanto ao procedimento formal mais solene, sendo esse requisito obrigatório apenas para os novos tratados. Verificamos, portanto, que a única diferença restaria na maior proteção conferida às normas, que, além de materialmente constitucionais, seriam também formalmente constitucionais, não sendo passíveis de denunciação pelas partes e não podendo ser reformadas (por força do parágrafo $4^{\circ}$ do artigo 60 da Constituição Federal). ${ }^{149}$

Ademais, conforme ensina Michel Temer ao tratar do fenômeno da recepção das normas infraconstitucionais anteriores à nova Constituição, “a nova ordem constitucional recepciona os instrumentos normativos anteriores dando-lhes novo fundamento de validade e, muitas vezes, nova roupagem”. ${ }^{150}$ A Emenda Constitucional, uma vez incorporada à Constituição, passa a ter hierarquia de norma constitucional, também se verificando o fenômeno da recepção.

Podemos introduzir o debate com os dizeres do ex-Ministro do Supremo Tribunal Federal, Francisco Rezek, que, ao dissertar sobre a natureza dos tratados internacionais de direitos humanos incorporados anteriormente à Emenda Constitucional n. 45/04, assim apôs:

\begin{abstract}
Uma última dúvida diz respeito ao passado, a algum eventual direito que um dia se tenha descrito em tratado de que o Brasil seja parte e que já não se encontre no rol do artigo $5^{\circ}$. Qual o seu nível? Isso há de gerar controvérsia entre os constitucionalistas, mas é sensato crer que ao promulgar esse parágrafo na Emenda constitucional 45, de 8 de dezembro de 2004, sem nenhuma ressalva abjuratória dos tratados sobre direitos humanos outrora concluídos mediante processo simples, o Congresso constituinte os elevou à categoria dos tratados de nível constitucional. Essa é uma equação jurídica da mesma natureza daquela que explica que nosso Código Tributário, promulgado a seu tempo como lei ordinária, tenha-se promovido a lei complementar à Constituição desde o momento em que a carta disse que as normas gerais de direito tributário deveriam estar expressas em diploma dessa estatura. ${ }^{151}$
\end{abstract}

\footnotetext{
${ }^{149}$ PIOVESAN, Flávia. Direitos Humanos e o Direito Constitucional Internacional. São Paulo: Saraiva, 2007.

150 TEMER, Michel Temer. Elementos de direito constitucional. 22. ed. São Paulo: Malheiros, 2008. p. 40.

${ }^{151}$ REZEK, Francisco. Direito Internacional Público: curso elementar. 11. ed. rev. e atual. São Paulo: Saraiva, 2008. p. 101-103.
} 
Ainda podemos argumentar que todos os tratados humanos anteriores à Emenda Constitucional obtiveram quórum superior ao de 3/5 de aprovação, deixando somente de ocorrer o $2^{\circ}$ turno de votação, uma vez que não era requisito exigido à época. ${ }^{152}$

O outro posicionamento verificou-se em recente decisão do Supremo Tribunal Federal, que alterou o seu antigo entendimento quanto à natureza jurídica dos tratados internacionais de direitos humanos, revelando que aqueles incorporados anteriormente à Emenda Constitucional n. 45 de 2004 teriam natureza diferenciada dos demais tratados internacionais, sobretudo se considerarmos o novo parágrafo inserido no artigo $5^{\circ}$, que determinou o regime jurídico misto dos tratados internacionais. Nesse sentido, o Supremo Tribunal reconheceu aos tratados internacionais de direitos humanos incorporados ao ordenamento jurídico sem a observância das formalidades do parágrafo $3^{\circ}$ do artigo $5^{\circ}$ da Constituição Federal a natureza de norma supralegal, embora infraconstitucional. ${ }^{153}$

Portanto, ainda que entendamos conforme doutrina mais formalista, que consideremos o requisito formal previsto no parágrafo $3^{\circ}$ do artigo $5^{\circ}$ condição essencial para que os tratados de direitos humanos incorporados no ordenamento pátrio adquiram status constitucional, compondo o bloco de constitucionalidade, havemos que considerar, ao menos, a natureza supralegal desse tratados, independentemente do quórum ou do momento de incorporação, conforme entendimento já firmado pelo Supremo Tribunal Federal.

Sendo assim, tendo status seja de norma constitucional seja de norma infraconstitucional, porém supralegal, o tratado internacional de diretos humanos é um acordo internacional de extrema importância que deve ser observado pelo legislador pátrio e servir de paradigma interpretativo.

Traçado esse panorama geral dos tratados internacionais e de sua incorporação ao ordenamento jurídico brasileiro, conforme vamos ver, por meio dos Tratados e Convenções internacionais abaixo citados, foi conferida, em âmbito internacional, proteção jurídica à pessoa desde o momento da concepção, bem como reconhecida sua qualidade de pessoa. E, conforme relatado inicialmente, tendo-se em vista que os tratados internacionais de direitos humanos quando incorporados no ordenamento jurídico brasileiro, mesmo que anteriormente à Emenda Constitucional n.45/04, teriam, ao ver do Supremo Tribunal Federal, natureza supralegal, a

\footnotetext{
152 PIOVESAN, Flávia. Temas de Direitos Humanos. 3. ed. São Paulo: Saraiva, 2009. p. 18.

${ }^{153}$ STF, RE 466.343, julgado em 03 de dezembro de 2008.
} 
legislação ordinária, inclusive o artigo $2^{\circ}$ do Código Civil, deve ser interpretada à luz do contido em tais tratados.

\subsubsection{Pacto de São José da Costa Rica}

O Pacto de São José é um Tratado Internacional de Direitos Humanos.

O Pacto de São José da Costa Rica, que promulgou a Convenção Americana sobre Direitos Humanos de 22 de novembro de 1969 e entrou em vigor em 1978, foi referendado pelo Congresso Nacional, ratificado pelo Presidente da República e incluído no ordenamento jurídico brasileiro por meio do Decreto n. 678, de 1992. Ele traz em seu artigo $3^{\circ}$ que "toda pessoa tem direito ao reconhecimento de sua personalidade jurídica” e em seu artigo $4^{\circ}$, ao tratar do direito à vida, dispõe que "1. Toda pessoa tem o direito de que se respeite sua vida. Esse direito deve ser protegido pela lei e, em geral, desde o momento da concepção. Ninguém pode ser privado da vida arbitrariamente”.

Da leitura do artigo $4^{\circ}$ do Pacto, portanto, podemos extrair que desde o momento da concepção deve ser protegida a vida da pessoa, levando-nos a concluir que o nascituro é pessoa. E da leitura do artigo $3^{\circ}$, no qual se determina que toda pessoa tem direito ao reconhecimento de sua personalidade jurídica, temos que o nascituro, como pessoa, também tem direito ao reconhecimento de sua personalidade jurídica.

Sem sombra de dúvidas, o Pacto de São José da Costa Rica veio exaltar a dignidade humana ao reconhecer a personalidade jurídica a todas as pessoas e proteger seus direitos básicos, tais como o direito à vida.

\subsubsection{Convenção Internacional sobre os Direitos da Criança}

A Convenção sobre os Direitos da Criança, de 1989, ratificada pelo Brasil em 24 de setembro de 1990, traz em seu texto legal o conceito de criança, entendendo-a como "todo ser 
humano menor de 18 anos de idade" (artigo $1^{\circ}$ ), asseverando que "os Estados-partes reconhecem que toda criança tem o direito inerente à vida” (art. $6^{\circ}-1$ ), não fazendo qualquer exclusão ao nascituro.

Do que consta do preâmbulo da Convenção, ainda podemos fazer referência ao seguinte excerto: “A criança, em virtude de sua falta de maturidade física e mental, necessita proteção e cuidados especiais, inclusive a devida proteção legal, tanto antes quanto após seu nascimento”, que serve de norte interpretativo aos artigos da Convenção.

Portanto, no que diz respeito à Convenção, pode-se extrair que é considerado pessoa todo ser humano, sem que haja qualquer distinção entre sua vida intra e extrauterina, o que nos leva à conclusão de que palavrão termo “pessoa” se aplica também ao nascituro.

\subsubsection{Pacto Internacional de Direitos Civis e Políticos das Nações Unidas}

O Pacto Internacional de Direitos Civis e Políticos das Nações Unidas, de 1966, ratificado pelo Brasil em 24 de janeiro de 1992, em seu artigo $6^{\circ}$, parágrafo $1^{\circ}$, reconhece que “o direito à vida é inerente à pessoa humana. Este direito deverá ser protegido pela Lei. Ninguém poderá ser arbitrariamente privado de sua vida”, e no artigo 16 aduz que "toda pessoa terá o direito, em qualquer lugar, ao reconhecimento de sua personalidade jurídica”.

\subsubsection{Recomendações do Conselho da Europa}

O Conselho da Europa é uma Organização Internacional fundada em 5 de maio de 1949, com personalidade jurídica reconhecida pelo Direito Internacional e cujos propósitos abarcam a defesa dos direitos humanos, o desenvolvimento democrático e a estabilidade político-social na Europa. É composto por 47 países europeus. Embora o Brasil dele não faça parte e nem possa fazer, as recomendações adotadas por tal Conselho são de grande importância internacional, refletindo o pensamento atual da sociedade, e, portanto, merecem comento. 
Nesse sentido, foram adotadas as Recomendações n. 934/82; n. 1046/86, 5; e n. 1100/89, 7, pelo Conselho da Europa, as quais enunciam a proteção da pessoa desde a concepção. ${ }^{154}$

\subsection{Código Civil}

O Direito Civil disciplina substancialmente as relações jurídicas de Direito Privado, tutelando os interesses particulares da pessoa, considerada em si mesma, nas suas relações patrimoniais e na sua relação familiar. Nesse sentido, Mota Pinto entende que "o Direito só pode ser concebido, tendo como destinatários os seres humanos em convivência”. ${ }^{155}$ Daí a importância do Código Civil; é ele que vai regular as relações jurídicas entre as pessoas, tornando possível a convivência e garantindo segurança e paz social. Por este mesmo motivo, as normas jurídicas presentes no Código Civil não devem ser analisadas isoladamente, mas apenas em seu aspecto objetivo, devendo ser considerado o sistema jurídico civil como um todo. Para que a norma seja interpretada, devemos observá-la também em seu aspecto subjetivo, valorativo, de acordo com a Constituição Federal - que traz a organização da sociedade política e as garantias dos cidadãos contra as arbitrariedades do Estado. É sob esse enfoque amplo que as normas jurídicas disciplinadas no Código Civil devem ser analisadas.

\subsubsection{Aspectos Anteriores ao Código Civil}

Anteriormente ao estabelecimento de um Código Civil brasileiro, as relações jurídicas privadas eram regradas pelo Decreto n. 181, de 24 de janeiro de 1890. Tomando-se por base o artigo $4^{\circ}$ desse Decreto, a personalidade jurídica tinha como pressuposto a viabilidade e o

\footnotetext{
${ }^{154}$ Cf. site do Conselho da Europa, disponível em: <www.coe.int>. Acesso em: 10 nov. 2009.

${ }^{155}$ PINTO, Carlos Alberto da Mota. Teoria Geral do Direito Civil, p. 84.
} 
nascimento, ${ }^{156}$ em contraponto aos dois Códigos privatistas que se seguiram e que não exigiram o requisito da viabilidade.

Em 1859, Teixeira de Freitas foi contratado pelo Governo Imperial para elaborar o primeiro anteprojeto de Código Civil. O autor sustentava o início da personalidade antes do nascimento. ${ }^{157}$ Nessa linha de entendimento inclinaram-se também Nabuco de Araújo e Felício dos Santos, contratados, sucessivamente, após rescisão do contrato de Teixeira de Freitas, para dar continuidade aos trabalhos. Com a proclamação da República, os ideários políticos mudaram, alterando-se também a escolha dos redatores do projeto de Código Civil. Assim, adveio a contratação de Clóvis Bevilaqua, que elaborou o projeto final do Código de 1916, aprovado pelo Congresso. Bevilaqua aceitava a doutrina de Teixeira de Freitas, admitido expressamente o início da personalidade a partir da concepção, condicionando-a, contudo, ao nascimento com vida. ${ }^{158}$ Porém, o Código Civil aprovado, após alterações durante o processo legislativo, trouxe diferente redação da prevista no Projeto de Bevilaqua, trazendo que o início da personalidade jurídica darse-ia apenas com o nascimento com vida. Clóvis Bevilaqua, em comentário ao Código Civil de 1916 já em vigor, explicou que a lei aludida adotou a teoria da personalidade civil com o nascimento, reservando ao nascituro apenas expectativa de direitos, por ser essa teoria mais prática. ${ }^{159}$

No entanto, ao que parece, a legislação apenas refletia o pensamento da época, em que pouco se conhecia sobre reprodução humana e desenvolvimento intrauterino, e segundo o qual mais se valorizava o "ter" que o "ser”.

O anteprojeto de 1972 do Código Civil de 2002 voltou a seguir a linha concepcionista. No projeto de 1975, no entanto, o qual teve como supervisor da Comissão Elaboradora e Revisora do Código Civil Miguel Reale e como integrantes da Comissão os juristas José Carlos Moreira Alves, Agostinho de Arruda Alvim, Sylvio Marcondes, Ebert Chamoun, Clóvis do Couto e Silva, e Torquato Castro, tal ideia foi afastada, sendo novamente sedimentado no texto legal que a personalidade jurídica iniciar-se-ia com o nascimento com vida, embora se resguardassem os direitos do nascituro; o que demonstra a constante inquietação que ronda o tema.

\footnotetext{
${ }^{156}$ BEVILAQUA, Clóvis. Código Civil dos Estados Unidos do Brasil Comentado. Edição histórica. Rio de Janeiro: Editora Rio. 1976. p. 177.

${ }^{157}$ TEIXEIRA DE FREITAS, Augusto. Esboço do Código Civil, 1983.

${ }^{158}$ BEVILAQUA, Clóvis. Teoria Geral do Direito Civil, p. 97.

${ }^{159}$ Idem. Código Civil dos Estados Unidos do Brasil Comentado, 1976.
} 


\subsubsection{O artigo $2^{\circ}$ do Código Civil}

Assim preceitua o artigo $2^{\circ}$ do nosso Código Civil: “A personalidade civil da pessoa começa do nascimento com vida; mas a lei põe a salvo, desde a concepção, os direitos do nascituro".

Alvo de constantes críticas, o artigo mencionado, que pouco destoou do antigo artigo $4^{\circ}$ do Código Civil de 1916, ${ }^{160}$ chama atenção, principalmente, para sua aparente redação contraditória, geradora de expressivo conflito interpretativo. Nesse sentido, para Paulo Nader “o modelo adotado não encontra embasamento na Teoria Geral do Direito, porque não há direito subjetivo sem titular, do mesmo modo que não há titular sem personalidade jurídica”. ${ }^{161}$

Algumas teorias da doutrina estrangeira tentaram explicar tal contradição legal, tais como a de Koeppen e Windscheid, que cogitaram a existência de direitos sem sujeito, ${ }^{162}$ ou a de Kohler, que imaginou a figura das pessoas jurídicas implícitas, mas nenhuma dessas teorias foi bem sucedida. ${ }^{163}$

Atualmente, ainda não há consenso na doutrina - estrangeira ou nativa - acerca do assunto.

Na doutrina brasileira, há quem interprete o artigo $2^{\circ}$ em sua primeira parte de modo literal e defenda a personalidade jurídica apenas com o nascimento com vida; existe também quem defenda uma personalidade condicional, com base no inteiro teor do artigo $2^{\circ}$; e, por fim, há quem, com base na segunda parte do artigo $2^{\circ}$ e fundamentando-se em uma interpretação sistemática, defenda a personalidade jurídica desde a concepção.

Conforme visto no capítulo 3, parece melhor a interpretação da corrente concepcionista, que se coaduna com a nova tendência do Direito Civil e Constitucional de valorização da pessoa humana e de sua dignidade.

\footnotetext{
${ }^{160} \mathrm{O}$ artigo $2^{\circ}$ do Código Civil praticamente repetiu o antigo artigo $4^{\circ}$ do Código Civil de 1916, apenas substituindo o termo "homem" por "pessoa”.

${ }^{161}$ NADER, Paulo. Curso de Direito Civil: parte geral. 4. ed. Rio de Janeiro: Forense, 2007.

${ }^{162}$ Cf. PONTES DE MIRANDA, Francisco Cavalcanti. Tratado de Direito Privado. Tomo I. Campinas: Bookseller, 2000. p. 217-218.

${ }^{163}$ CARVALHO SANTOS, João Manuel de. Código Civil Brasileiro Interpretado, principalmente do ponto de vista prático. v. 1. 15. ed. Rio de Janeiro: Freitas Bastos, 1992. p. 248.
} 


\subsubsection{Demais Referências ao Nascituro no Código Civil}

O Código Civil faz referência em vários artigos a direitos do nascituro, mas não o faz de maneira exaustiva. ${ }^{164}$ Assim, a jurisprudência tem complementado os direitos do nascituro, o que se coaduna com a defesa de que o nascituro teria todos os direitos da personalidade compatíveis com a sua natureza. Ao que parece, o Código Civil apenas arrolou direitos mínimos do nascituro, os quais pretendeu resguardar da ingerência do homem.

Nesse sentido, a doutrina aponta alguns artigos do Código Civil como referentes aos direitos do nascituro. São eles: 542, 1.596, 1.597, 1609, parágrafo único, 1.630, 1.633, 1.779, 1.784, 1.798, 1.799, inciso I, e 1800, parágrafo $3^{\circ}{ }^{165}$

Os direitos patrimoniais do nascituro são tratados no artigo 542, que trata da possibilidade de doação ao nascituro. Os artigos 1.784 e 1.798 tratam do direito à sucessão legítima do nascituro. Por fim, os artigos 1.799, inciso I, e 1.800, parágrafo $3^{\circ}$, tratam da sucessão testamentária da prole eventual. ${ }^{166}$ Reconhecem, assim, esses artigos, a capacidade do nascituro para suceder. Cabe aqui um adendo referente à discussão existente na doutrina sobre se estes direitos estariam sob condição resolutiva ou condição suspensiva. Para uns, esses direitos estariam sob condição suspensiva, só havendo direito à sucessão a partir do nascimento com vida. ${ }^{167}$ Já para outros, esses direitos estariam sob condição resolutiva: o nascimento com vida apenas consolidaria o direito patrimonial e somente em caso de não nascimento não haveria direito à sucessão. ${ }^{168}$

Podemos ainda citar artigos que versam sobre os direitos pessoais do nascituro, quais sejam, os artigos 1.596 e 1.597 do Código Civil, que tratam do direito à filiação, e o artigo 1.609, parágrafo único, que trata do direito ao reconhecimento de filiação. E, ainda, os artigos 1.630 e

\footnotetext{
164 Nesse sentido, há julgados em diferentes tribunais reconhecendo o direito do nascituro a alimentos. Cf., por exemplo, TJMG, Ap. Cív. n. 1.0024.04.377309-2/001; TJRS, Agravo n. 70016977936; TJSP, Ap. Cív. n. 193.648-1.

165 Nesse sentido, cf. MONTORO, André Franco; FARIA, Anacleto de Oliveira. Condição Jurídica do Nascituro no Direito Brasileiro, p. 33-44; CHINELLATO, Silmara Juny de Abreu. Tutela Civil do Nascituro, p. 206-233; DINIZ, Maria Helena. Curso de Direito Civil Brasileiro, v. 1, p. 197.

${ }^{166}$ Acerca do artigo 1.798, a III Jornada do Conselho da Justiça Federal aprovou o seguinte enunciado: Enunciado CJF, 267: “Art. 1.798: A regra do art. 1.798 do Código Civil deve ser estendida aos embriões formados mediante o uso de técnicas de reprodução assistida, abrangendo, assim, a vocação hereditária da pessoa humana a nascer cujos efeitos patrimoniais se submetem às regras previstas para a petição da herança”. Disponível em: <www.cjf.jus.br> . Acesso em: 10.11.2009.

167 NERY JÚNIOR, Nelson; NERY, Rosa Maria de Andrade. Código Civil Comentado, p. 201.

${ }^{168}$ CHINELLATO, Silmara Juny de Abreu. Estatuto Jurídico do Nascituro, p. 53.
} 
1.633, que tratam do poder familiar e levam ao entendimento de que cabe aos pais a defesa dos direitos do nascituro e, na falta destes, ao curador, conforme artigo 1.779 e parágrafo único, que trata da curatela ao nascituro. ${ }^{169}$

\subsection{Legislação Civil Extravagante}

A legislação civil extravagante também deve ser observada, mesmo que brevemente, no estudo do nascituro.

Nesse sentido vamos analisar alguns dispositivos do Estatuto da Criança e do Adolescente, do Código de Defesa do Consumidor, da Lei de Biossegurança e da Lei de Alimentos Gravídicos.

O Estatuto da Criança e do Adolescente (ECA), ${ }^{170}$ foi concebido com o fim de assegurar a proteção integral da criança e do adolescente, considerando-se criança a pessoa de até 12 anos de idade incompletos, conforme seus artigos $1^{\circ}$ e $2^{\circ}$. Desde logo, já se pode observar que para o Estatuto criança é pessoa e que a lei não estabeleceu idade mínima para criança, mas apenas referiu-se ao limite máximo.

Ressalta-se, ainda, que o Estatuto prevê em seu artigo $7^{\circ}$ que a criança e o adolescente terão garantida a proteção à vida e à saúde, por meio de políticas sociais públicas que permitam $o$ nascimento e o desenvolvimento sadio, harmonioso, em condições dignas. E, em seu artigo $8^{\circ}$, caput e parágrafo $3^{\circ}$, garante à gestante o atendimento pré e perinatal no Sistema Único de Saúde, bem como o apoio alimentar. A lei protege, portanto, não somente a saúde da gestante, mas também a do nascituro, pois se visa garantir o nascimento sadio da criança, é evidente que deve proporcionar condições adequadas durante a gestação, o que faz ao assegurar atendimento médico e alimentar à gestante necessitada.

\footnotetext{
${ }^{169}$ Nesse sentido, ainda, o Código de Processo Civil Brasileiro traz, em seus artigos 877 e 878, a medida cautelar de posse em nome do nascituro, fazendo referência expressa à garantia dos “direitos do nascituro”.

${ }^{170}$ BRASIL. Lei federal n. 8.069 de 13 de julho de 1990. Dispõe sobre o Estatuto da Criança e do Adolescente e dá outras providências. D.O.U. 16.7.1990.
} 
Nesse sentido, observa-se o acórdão do STJ julgado por unanimidade em 20 de março de 1995, em que se entendeu que o ECA abarca a proteção ao nascituro:

ESTATUTO DA CRIANÇA E DO ADOLESCENTE. CRIME DE PROMESSA DE ENTREGA DE FILHO MEDIANTE PAGA OU RECOMPENSA. O VOCÁBULO "FILHO", EMPREGADO NO TIPO PENAL DO ART. 238 DA LEI 8.069/90, ABRANGE TANTO OS NASCIDOS COMO OS NASCITUROS. TODAVIA, A PROPOSTA GENÉRICA, SEM ENDEREÇO CERTO, SEM VÍNCULO DE QUALQUER NATUREZA ENTRE A PROMITENTE E TERCEIRA PESSOA QUE SE PROPONHA A REALIZAR A CONDIÇÃO, E ATO UNILATERAL IMPERFEITO, SEM MAIORES CONSEQUENCIAS, QUE NÃO PREENCHE OS ELEMENTOS ESSENCIAIS DO TIPO EM EXAME. RECURSO ESPECIAL NÃO CONHECIDO. (REsp. 48.119-8/RS, Ministro Relator Assis Toledo, $5^{\mathrm{a}}$ Turma, julgado em 20.03.1995, DJ 17.04.1995, p. 9587).

O Código de Defesa do Consumidor, ${ }^{171}$ por sua vez, em seu artigo $6^{\circ}$, traz os direitos básicos do consumidor, e entre eles está a proteção à vida, à saúde e à segurança. Tal artigo pode ser invocado para proteção do nascituro, equiparando-o, portanto, a um consumidor.

Nesse sentido, Silmara Juny de Abreu Chinellato exemplifica a possibilidade de o nascituro ser consumidor nos casos de medicamentos a ele destinados e serviços médicos prénatais, podendo ou não estar acompanhado de serviços ou produtos. ${ }^{172}$

A Lei de Biossegurança, já comentada neste trabalho, também trouxe dispositivos relativos ao nascituro. Em seus artigos $5^{\circ}, 6^{\circ}$, inciso III, e 25, por exemplo, se refere aos embriões pré-implantatórios, de forma a evidenciar e respaldar a defesa da natureza jurídica de pessoa do nascituro. Tal lei só permite a utilização de células-tronco embrionárias obtidas de embriões inviáveis e/ou congelados há mais de 3 anos após consentimento dos genitores e apenas para fins de pesquisa e terapia, protegendo a integridade física do embrião. ${ }^{173}$

Ainda podemos citar a Lei de Alimentos Gravídicos, ${ }^{174}$ recentemente editada, que regula o direito da mulher gestante a alimentos. A crítica que pode ser feita a essa lei refere-se à expressão “alimentos gravídicos”, pois o direito aos alimentos não é da gravidez, nem da gestante, mas sim do nascituro, que tem direito ao pleno desenvolvimento, conforme, inclusive, já vinha sendo reconhecido pela doutrina e pelos nossos tribunais, mesmo antes da referida lei. ${ }^{175}$

\footnotetext{
${ }^{171}$ BRASIL. Lei federal n. 8.078 de 11 de setembro de 1990. Dispõe sobre a proteção do consumidor e dá outras providências. D.O.U. 12.09.1990.

${ }^{172}$ CHINELLATO, Silmara Juny de Abreu. Tutela Civil do Nascituro, p. 287.

173 TARTUCE, Flávio. Situação Jurídica do Nascituro. In: DELGADO, Mário Luiz; ALVES, Jones Figueirêdo. (Coord.). Questões Controvertidas no Novo Código Civil, v. 6, p. 95.

${ }^{174}$ BRASIL. Lei federal n. 11.804 de 5 de novembro de 2008. Disciplina o direito a alimentos gravídicos e a forma como ele será exercido e dá outras providências. D.O.U. 06.11.2008.

${ }^{175}$ Nesse sentido: RT 703/60-63.
} 


\section{O NASCITURO COMO PESSOA}

Se até o século XII não se pensava no indivíduo como pessoa, após o fenômeno do Constitucionalismo e das Codificações dos séculos XVIII e XIX, ficou estabelecido, de uma vez por todas, o primado de que todo ser humano é pessoa, autora e destinatária do Direito.

No capítulo anterior, foi feito um breve estudo sobre o tratamento do nascituro no ordenamento jurídico brasileiro e neste capítulo vamos desenvolver o entendimento do nascituro como pessoa.

Numa primeira parte, apresentaremos a ideia de nascituro como sujeito de direitos. Na segunda parte deste capítulo, por sua vez, serão apresentados os direitos da personalidade do nascituro.

\subsection{O Nascituro como Sujeito de Direitos}

O conceito de nascituro trazido pela doutrina frequentemente faz referência a "pessoa por nascer”. O Dicionário Aurélio, ao definir nascituro, traz: “[Do lat. Nascituru.] Adj. 1. Que há de nascer. S. m. 2. Aquele que há de nascer. 3. Jur. O ser humano já concebido, cujo nascimento se espera como fato futuro certo". ${ }^{176}$

A grande polêmica que se instaura e deve, neste momento, ser enfrentada, pode ser resumida numa simples pergunta: é o nascituro “pessoa” na acepção jurídica do termo?

Na defesa do nascituro como pessoa em seu sentido ontológico, podemos trazer à baila a opinião do jurista e filósofo português Mário Bigotte Chorão, que assim entende:

Com apoio em dados científicos, é possível sustentar que desde a fecundação existe um novo indivíduo da espécie humana, com uma identidade genética própria, cujo organismo se vai desenvolvendo autônoma, coordenada, contínua e gradualmente,

\footnotetext{
${ }^{176}$ FERREIRA, Aurélio Buarque de Holanda (Ed.). Novo Aurélio Século XXI: o dicionário da língua portuguesa. 3. ed. Rio de Janeiro: Nova Fronteira, 1999. Grifos nossos.
} 
segundo uma lei ontogenética e um plano unificador intrínsecos, num processo vital sem fissuras, que se prolonga pela fase pós-natal, até a morte. ${ }^{177}$

Por fim, o autor conclui que o nascituro, a partir da fecundação é verdadeira pessoa humana, com todos os requisitos biológicos e ontológicos, pois onde há corpo humano há pessoa, independentemente do cabal desenvolvimento de todas as suas potencialidades.

Nesse sentido, Rabindranath Capelo de Sousa aduz:

\begin{abstract}
Ora, sendo a vida humana um processo moldado numa certa natureza, importa ter presente que na caracterização da natureza humana, em si mesma, não será decisivo o grau de sua evolução, mas a sua estrutura e dinâmica. Parece, assim, inegável a existência da vida humana no nascituro concebido, uma vez que ele, desde a concepção, emerge como um ser dotado de uma estrutura e de uma dinâmica humanas autônomas, embora, funcionalmente dependente da mãe. ${ }^{178}$
\end{abstract}

Reconhecida a natureza de ser humano do nascituro, arguir pelo não reconhecimento de sua personalidade com base apenas na sua dependência funcional, ignorando sua estrutura humana autônoma, parece um argumento desprovido de sustentação lógica.

Nesse sentido, Diogo Leite de Campos equipara o nascituro ao recém-nascido, tanto na falta de autonomia, quanto na capacidade de relação, aduzindo que diferenciar um do outro, tratando um como pessoa e o outro não, seria ferir os princípios da igualdade e da dignidade humana, que devem ser observados em todas as fases de desenvolvimento do ser humano. Afirma, ainda, que "qualquer norma que se refira à personalidade jurídica não é constitutiva: não é mais que o reconhecimento de uma realidade, de um 'direito’”,179 e conclui que a personalidade jurídica pertence a todo indivíduo vivo.

Ainda, Diogo Leite de Campos, entende que o conceito tradicional de início da personalidade está ultrapassado e que as normas que vinculam o início da personalidade ao nascimento, presentes na maioria das legislações, traduzem um conceito pré-científico. Para o autor, o nascimento não é um começo, mas um passo; com as modernas técnicas de reconhecimento da vida intrauterina, afirmar que "o nascituro é algo de diferente de um ser

\footnotetext{
${ }^{177}$ CHORÃO, Mário Bigotte. Pessoa humana, direito e política, p. 436-437.

${ }^{178}$ CAPELO DE SOUSA, Rabindranath Valentino Aleixo. . O direito geral de personalidade. Portugal: Coimbra Editora, 1995. p. 160.

${ }^{179}$ CAMPOS, Diogo Leite de. A capacidade sucessória do nascituro (ou a crise do positivismo legalista, p. 49-51.
} 
humano é recuar para uma época em que os conhecimentos da biologia eram inexistentes ou quase”. 180

Entender, portanto, o nascituro como pessoa, nada mais consiste do que reconhecer o que é lhe de direito, ou seja, reconhecer sua natureza inegavelmente humana.

Esse também é, sem dúvida, o entendimento que podemos retirar dos julgados dos tribunais brasileiros, seja quando reconhecem ao nascituro direitos não expressos na legislação tal como se deu em relação ao reconhecimento do direito do nascituro a alimentos, antes mesmo da Lei de Alimentos Gravídicos ${ }^{181}$-, seja por conferir-lhe legitimidade para propositura de ações, mediante representação, pela defesa de seus direitos; ${ }^{182}$ ou, ainda, por expressamente aduzir a qualidade de pessoa do nascituro. ${ }^{183}$

${ }^{180}$ CAMPOS, Diogo Leite de. A capacidade sucessória do nascituro (ou a crise do positivismo legalista, p. 50.

${ }^{181}$ Podemos verificar o reconhecimento do direito do nascituro a alimentos em diversos julgados anteriores à Lei de Alimentos Gravídicos, como por exemplo, na Ap. Cív. 193.648-1/5, julgada em 14/09/93, no Tribunal de Justiça de São Paulo, e relatada pelo Des. Renan Lotufo (RT 703/60-63), bem como, na Ap. n. 1999.001.01187, julgada pelo Tribunal de Justiça do Rio de Janeiro, em 1999, cujo Relator foi o Desembargador Luiz Roldão F. Gomes.

${ }^{182}$ Nesse sentido, foi decidido pelo TJSP em 1993 que: “Ao nascituro assiste capacidade para ser parte. O nascimento com vida investe o infante na titularidade da pretensão de direito material, até então apenas uma expectativa resguardada.” (Ap. Cív. 193.648-1/5, DJ. 14/9/93, Rel. Renan Lotufo). No mesmo sentido, o Órgão Especial do Tribunal de Justiça de São Paulo, no AI 137.023-0/00, reconheceu a legitimidade do nascituro para entrar com ação judicial visando ao atendimento médico da mãe, de modo a garantir seu direito ao desenvolvimento sadio. No Tribunal de Justiça do Rio Grande do Sul verificamos julgados nesse sentido desde 1984, conforme Ap. Cív. n. 583052204, a qual se seguiram inúmeras outras. O Tribunal de Justiça de Minas Gerais, por sua vez, tem decisão conferindo legitimidade ao nascituro para propositura de ações na defesa de seus direitos datada de 1987, conforme RT 625/172. O mesmo entendimento pode ser visto no Tribunal de Justiça do Rio de Janeiro, conforme Ap. n. 199.001.01187.

${ }^{183}$ Nesse sentido, o Tribunal de Justiça do Rio Grande do Sul traz os seguintes exemplos: Rec. Cív. n. 71001157478; Rec. Cív. n. 71000611665; e Ap. Cív. n. 70002027910. O Tribunal de Justiça de São Paulo, na Ap. Cív. n. 1.112.266-2 também trouxe entendimento favorável ao nascituro, assegurando-lhe todos os direitos fundamentais da personalidade na sua mais larga acepção, que, por sua relevância, aqui transcrevemos: “ACÓRDÃO COISA JULGADA - Responsabilidade civil - Acidente de trânsito - Vítima fatal - Ação proposta em decorrência do falecimento do pai do autor (quando este ainda não tinha nascido), em atropelamento que envolveu um caminhão da ré - Propositura que se deu contra a empresa proprietária do caminhão, a qual, 7 anos antes, celebrara acordo com a mãe do autor, abarcando direitos de ambos, o dela e o do filho, então nascituro - Nascituro tem assegurados todos os direitos fundamentais da personalidade, na sua mais larga acepção - Sua representação se faz pelas figuras paterna e materna, dentro das regras gerais do pátrio poder, que apenas cedem passo à curatela prevista no art. 462 do CC/1916, quando falecido o pai, ou a mulher grávida não detenha o pátrio poder, por ser interdita, ou incapaz por alienação mental, ou lhe seja retirada, por sentença, a "pátria potestas", já que a morte do marido importa em transferência direta e automática do poder parental para a mãe - Sendo legal a transação, que obedeceu aos requisitos de validade do ato jurídico, há de se respeitar o princípio da autonomia da vontade, que se particulariza na liberdade de contratar - Precedente acordo extrajudicial firmado entre a ré e o autor (então nascituro, mas representado por sua mãe) é equiparável à sentença irrevogável, adquire os efeitos da coisa julgada (CC/1916, art. 1.030) e pode ser oposto à outra parte - Negativa de seguimento a agravo interposto contra a manutenção do autor no pólo ativo da lide - Irrelevância - Possibilidade de a matéria de ordem pública ser conhecida a qualquer tempo e grau de jurisdição, não ficando na dependência de opção do litigante - Reconhecimento de extinção do processo, sem exame do mérito, nos termos do art. 267, V, do CPC - Recurso da ré provido e recurso do autor prejudicado.” (Ap. Cív. n. 1.112.266-2, j. 19.03.2003, Rel. Des. Álvaro Torres Júnior). 
Relativamente à possibilidade de incluir o nascituro no polo ativo de uma demanda, Carlos Alberto Bittar entende que:

\begin{abstract}
a titularidade de direitos, com respeito às pessoas físicas, não exige qualquer requisito, ou condição pessoal: todas as pessoas naturais, nascidas ou nascituras, capazes ou incapazes, podem incluir-se no pólo ativo de uma ação reparatória, representadas, nos casos necessários, conforme a lei o determina (nesse sentido, menores são representados pelos pais; loucos, pelos curadores; silvícolas, pela entidade tutelar e assim por diante). ${ }^{184}$
\end{abstract}

Para o autor, o nascituro teria, portanto, legitimidade para, representado, ajuizar ação, ficando evidente a distinção entre falta de capacidade e falta de legitimidade.

Na defesa da legitimidade do nascituro para propositura de ações na defesa de seus direitos, mesmo para quem entende que o nascituro tem direito eventual sob condição suspensiva (e não resolutiva), podemos nos valer do artigo 130 do Código Civil que assim traz: “Ao titular do direito eventual, nos casos de condição suspensiva ou resolutiva, é permitido praticar os atos destinados a conservá-lo”. Se o direito material reconhece essa possibilidade, é possível que o nascituro seja parte processual (representado pelos pais), e o direito processual, devido ao seu caráter instrumental, é que deve se adaptar.

Nesse sentido, o Órgão Especial do Tribunal de Justiça de São Paulo reconheceu recentemente, ${ }^{185}$ no Agravo n. 137.023-0/00, a legitimidade ativa do nascituro, devidamente representado, para garantir o atendimento médico da mãe:

\begin{abstract}
MENOR - Ação proposta por nascituro buscando o atendimento pré-natal à sua genitora, que se encontra presa - Decisão do juiz a quo que determinou a emenda da inicial por entender que o nascituro, por não possuir personalidade jurídica, não tem legitimidade ativa ad causam - Não conhecimento do agravo no tocante ao pleito que visa a concessão da antecipação da tutela ainda não apreciada em primeira instância Nascituro que pode ser parte, desde que representado pelos genitores ou por quem determina a lei civil - Provimento do agravo apenas para reconhecer a possibilidade do nascituro vir a juízo, sem adentrar no mérito de sua legitimidade para a causa presente e, tampouco, a competência da Justiça da Infância e da Juventude - Necessidade de anulação do despacho que determinou a emenda da inicial - Agravo conhecido em parte e, na parte conhecida, provido, nos termos do acórdão. (Agravo n. 137.023-0/00, Desembargador José Mário Antônio Cardinale, Órgão Especial do TJSP)
\end{abstract}

É importante ainda constatar que, com base em método lógico-sistemático de hermenêutica, partindo da análise da Constituição Federal, permeando os tratados internacionais e servindo-se do artigo $2^{\circ}$ do Código Civil em conjunto com o restante do ordenamento jurídico-

\footnotetext{
${ }^{184}$ BITTAR, Carlos Alberto. Reparação Civil por danos morais. São Paulo: Revista dos Tribunais, 1999. p. 153.

185 Já havia precedente no próprio Tribunal de Justiça de São Paulo: Ap. Cív. 193.648-1, DJ. 14/9/93, Rel. Renan Lotufo.
} 
civilístico, é possível afirmar que, de modo geral, o nosso ordenamento trata o nascituro como pessoa, uma vez que lhe confere direitos e lhe dá proteção, devendo, portanto, ser respeitada sua dignidade.

E, à parte as posições divergentes, ficamos com Euclides Benedito de Oliveira, para quem o nascituro é “considerado como 'pessoa' desde a concepção, seja como spes homini, pessoa em formação, o certo é que o nascituro tem assegurado todos os direitos fundamentais da personalidade, na sua mais larga acepção”. 186

\subsection{Direitos da Personalidade e o Nascituro}

Consideram-se direitos da personalidade ${ }^{187}$ os direitos inerentes à própria condição de pessoa humana, tomados em si mesmos e em suas projeções na sociedade, podendo ou não constar do ordenamento jurídico. ${ }^{188}$

Conforme San Tiago Dantas, “a construção de uma categoria à parte, de direitos tendo por conteúdo os próprios bens da personalidade, é obra da doutrina moderna, especialmente da doutrina germânica da última metade do século passado em diante”. ${ }^{189}$

Carlos Alberto Bittar ressalta as dificuldades que são encontradas na conceituação e na classificação dos direitos da personalidade, embora já existam orientações básicas no assunto. Atribui tais dificuldades a três fatores principais: (i) a divergência dos doutrinadores quanto à extensão, à natureza e à especificação desses direitos; (ii) o caráter novo de sua construção

\footnotetext{
186 OLIVEIRA, Euclides Benedito de. Indenização por danos morais ao nascituro. In: DINIZ, Maria Helena; LISBOA, Roberto Senise (Coord.). O Direito Civil no século XXI. São Paulo: Saraiva, 2003. p. 161.

${ }^{187}$ A doutrina diverge quanto à denominação a ser dada a esses direitos. Os doutrinadores têm-se inclinado para os seguintes nomes: “direitos à personalidade” ou "essenciais”, conforme De Cupis; “direitos personalíssimos”, conforme Pugliati, entre outras denominações, e, preferencialmente, “direitos da personalidade”, conforme Gierke, Ferrara, Bittar, Orlando Gomes, Limongi França, Antônio Chaves, Silmara Juny de Abreu Chinellato, entre outros. Neste trabalho, vamos utilizar a denominação “direitos da personalidade”, expressão à qual a doutrina mais moderna se inclina.

${ }^{188}$ Aqui, adotamos a concepção naturalista, segundo a qual se entende serem os direitos da personalidade inerentes à condição de homem, subsistindo independentemente de codificação. A contrario sensu, há a corrente positivista, que entende serem direitos subjetivos apenas os reconhecidos pelo Estado.

${ }^{189}$ SAN TIAGO DANTAS, F. C. Programa de Direito Civil: parte geral, p. 20.
} 
teórica sem um conceito definitivo; e (iii) a diversificação de enfoques dados ao assunto pelo Direito Público. ${ }^{190}$

Mesmo com todas as dificuldades para estabelecer a abrangência e a natureza dos direitos da personalidade, após percorrerem um longo e tortuoso caminho, tais direitos adquiriram referência no Código Civil brasileiro. O diploma referido deles trata em seu Livro I, no intuito de conferir-lhes maior proteção, embora não apresente rol taxativo. ${ }^{191}$

O certo é que a busca da conceituação de direito da personalidade, embora seja ele um direito autônomo, deve ser feita tendo em vista os outros ramos do conhecimento mais diretamente ligados à compreensão do ser humano. ${ }^{192}$

Para Orlando Gomes, os direitos da personalidade são os "direitos considerados essenciais ao desenvolvimento da pessoa humana” e "destinam-se a resguardar a eminente dignidade da pessoa humana”. 193

Capelo de Sousa, doutrinador português, no estudo dos direitos da personalidade com base no Código Civil de Portugal, diz que, ao se falar de tutela dos direitos da personalidade, fala-se em tutela dos "bens inerentes à própria materialidade e espiritualidade de cada homem”. 194

Desses pontos de vista, extraímos que o direito da personalidade é, portanto, a qualidade necessária do ser humano, a sua propriedade natural e inseparável.

Diante de um panorama geral dos direitos da personalidade, temos que podem ser analisados sob o prisma de seu relacionamento com o Estado ou sob o enfoque das relações privadas, sendo sua natureza a de direito subjetivo na opinião da maioria dos doutrinadores do assunto, visto que são ínsitos das pessoas, considerada sua estruturação física, moral e psíquica. São, também, direitos irrenunciáveis e intransmissíveis, conforme, inclusive, se verifica no Código Civil, em seu artigo 11, o que não impede que, por outro lado, seu titular deles disponha, tal qual o direito à imagem e ao próprio corpo, no caso de doação de órgãos.

\footnotetext{
${ }^{190}$ BITTAR, Carlos Alberto. Os Direitos da personalidade. São Paulo: Forense, 2003. p. 2.

191 Nesse sentido, a IV Jornada de Direito Civil do Conselho da Justiça Federal, aprovou o Enunciado 274: “Os direitos da personalidade, regulados de maneira não exaustiva pelo Código Civil, são expressões da cláusula geral de tutela da pessoa humana contida no art. $1^{\circ}$, III, da Constituição (princípio da dignidade da pessoa humana). Em caso de colisão entre eles, como nenhum pode sobrelevar os demais, deve-se aplicar a técnica da ponderação”. Disponível em: <www.cjf.jus.br>. Acesso em: 10 nov. 2009.

${ }^{192}$ CAPELO DE SOUSA, Rabindranath Valentino Aleixo. O direito geral de personalidade, p. 110.

${ }^{193}$ GOMES, Orlando. Introdução ao direito civil geral. Rio de Janeiro: Forense, 1979. p. 168.

${ }^{194}$ CAPELO DE SOUSA, Rabindranath Valentino Aleixo. Op. cit., p. 106.
} 
Apesar de a Constituição Federal fazer referência a alguns dos direitos aqui tratados, de o Código Civil atual dedicar a outros direitos capítulo próprio e, inclusive, de haver menção a um ou outro desses direitos em legislação esparsa, o Direito positivo não esgota o rol dos direitos da personalidade, seja por faltar de maior desenvolvimento teórico do assunto, seja pela complexidade de tais direitos, que podem surgir de acordo com a necessidade de proteção. Mas estejam ou não positivados, deve ser feita uma leitura da responsabilidade civil, no que lhes diz respeito, à luz da Constituição Federal e do princípio vetor da dignidade humana.

E, na opinião de alguns doutrinadores, embora subsista o caráter inato dos direitos da personalidade, sua natureza e sua projeção no mundo exterior, preexistentes ao direito positivo e dele independentes, carecem, ainda assim, de especial regulamentação para dotá-los de proteção própria e específica, constitucionalmente ou não, contra possíveis incursões de particulares ou abusos do Estado, conferindo-lhes maior dignidade.

Tendo em vista a dificuldade de dimensionar os direitos em causa, podemos encontrar as mais diferentes classificações. Capelo de Sousa alude a uma classificação na qual há, primeiro, uma subdivisão dos direitos da personalidade em função de uma personalidade física e uma moral e, após, uma ramificação dessas subdivisões em tipos mais específicos. ${ }^{195}$ Entre os doutrinadores brasileiros, Limongi França divide esses direitos em: direitos relativos à integridade física (direito à vida, à alimentação, ao corpo e às partes), direitos relativos à integridade intelectual (direito à liberdade de pensamento, pessoal do autor e do inventor) e direitos relativos à integridade moral (direito à honra, à liberdade, ao recato, ao segredo, à identidade, à imagem e ao nome). ${ }^{196}$

Orlando Gomes, por sua vez, alude à seguinte divisão: os direitos relativos à integridade física (direito à vida, sobre o próprio corpo e ao cadáver) e os direitos à integridade moral (direito à honra, à liberdade, ao recato, à imagem, ao nome e direito moral do autor). ${ }^{197}$ Carlos Alberto Bittar entende haver a divisão em: direitos físicos (referentes a componentes materiais da estrutura humana, ou seja, o direito à vida, à integridade física, ao próprio corpo, ao cadáver e às partes, à imagem e à voz), direitos psíquicos (relativos a elementos intrínsecos à personalidade e à integridade psíquica, compreendendo a liberdade, a intimidade, a integridade psíquica e o

\footnotetext{
${ }^{195}$ CAPELO DE SOUSA, Rabindranath Valentino Aleixo. O direito geral de personalidade, p. 123.

${ }^{196}$ LIMONGI FRANÇA, Rubens. Direitos da personalidade: coordenadas fundamentais. Revista dos Tribunais, São Paulo, v. 567, 1983, p. 13.

${ }^{197}$ GOMES, Orlando. Direitos de personalidade. Revista Forense, Rio de Janeiro, v. 216, 1966, p. 8.
} 
sigilo) e direitos morais (referindo-se a atributos valorativos da pessoa na sociedade, à honra, ao respeito, a manifestações do intelecto e à identidade). ${ }^{198}$

A inexistência de um rol imutável sobre os direitos da personalidade e a adoção de classificação flexível tornam possível o reconhecimento de novos direitos que a reflexão irá revelar. Para fins de nossos estudos, não há necessidade de se ater a uma ou outra classificação, mas o que se deve reconhecer é a existência de direitos inerentes à pessoa humana, que, independentemente de sua codificação ou classificação, merecem proteção. E, em caso de colisão entre eles, deve-se utilizar a técnica da ponderação.

Ademais, ainda há que se ater ao fato de que qualquer lesão aos direitos da personalidade, na esfera civil, deve ser reparada, com fundamento na responsabilidade civil. Além disso, embora os direitos da personalidade sejam personalíssimos e intransmissíveis, o direito de exigir a reparação pecuniária transmite-se aos sucessores, conforme determinação do artigo 943 do Código Civil. ${ }^{199}$

Visto o panorama geral dos direitos da personalidade, resta saber se são eles também conferidos ao nascituro e se, portanto, devem ser eles protegidos.

Capelo de Sousa, quanto ao nascituro, entende que

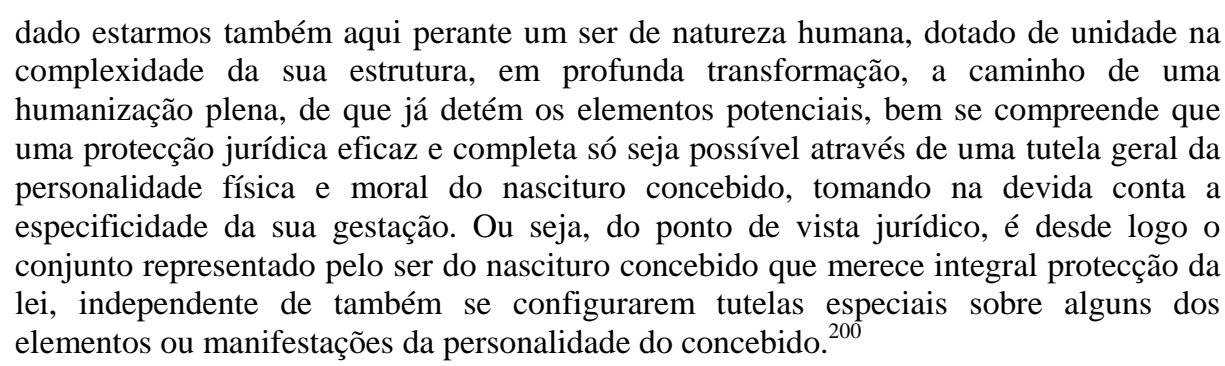

Portanto, reconhecida a natureza humana do nascituro, bem como alguns direitos, não restam dúvidas de que a proteção ampla dos direitos da personalidade também inclui o nascituro. Tem assim, o nascituro, direito à vida, à saúde, à integridade físico-psíquica, à honra, à imagem, ao nome e à intimidade, ${ }^{201}$ entre outros direitos que possam a ele ser atribuídos, de acordo com sua natureza. A violação a qualquer expressão da personalidade ou da dignidade da pessoa humana enseja a responsabilização civil e a consequente obrigação de reparar o dano.

\footnotetext{
${ }^{198}$ BITTAR, Carlos Alberto. Os direitos da personalidade, p. 17.

199 Cf. GONÇALVES, Carlos Roberto. Direito Civil Brasileiro: Responsabilidade Civil. v. 5. 2. ed. São Paulo: Saraiva, 2007. p. 368.

${ }^{200}$ CAPELO DE SOUSA, Rabindranath Valentino Aleixo. O direito geral de personalidade, p. 161.

${ }^{201}$ CHINELLATO, Silmara Juny de Abreu. Estatuto Jurídico do Nascituro: O direito brasileiro, p. 53.
} 


\section{RESPONSABILIDADE CIVIL POR DANO CAUSADO AO NASCITURO}

A teoria da responsabilidade civil busca, em última análise, restaurar uma igualdade destruída, ${ }^{202}$ ou seja, almeja restituir o estado anterior, reparando o dano sofrido injustamente ou, ao menos, minimizando a situação. Busca-se, portanto, a restauração de um estado igualitário, independentemente do fundamento que seja dado, se culpa ou risco.

No entanto, antes de chegar às feições atuais, o instituto da responsabilidade civil passou por algumas mudanças, evoluindo muito desde seu surgimento. Num primeiro momento, apenas a ideia de culpa servia de fundamento para obrigação de indenizar, e o princípio geral da não responsabilidade sem culpa, consolidado na Idade Moderna, foi o adotado nos primeiros códigos civis. Numa segunda etapa, mais precisamente no último século, tendo em vista as mudanças sociais experimentadas com a Revolução Industrial (incluindo-se aí o aumento dos riscos existentes e o impulso em direção à valorização da pessoa humana, motivando as pessoas a recusarem a desgraça e a buscarem a reparação de todo o mal sofrido), o fundamento consubstanciado apenas na culpa se tornou insuficiente frente a todos os males vivenciados, tornando-se necessária a busca por uma nova modalidade de responsabilização civil. ${ }^{203}$

A sociedade pós-moderna exige cada vez mais o respeito a seus direitos e à sua dignidade, buscando um sistema de responsabilização civil que tenha por objetivo alcançar um número cada vez maior de vítimas ressarcidas, face à nova realidade social, econômica e tecnológica. ${ }^{204}$ Os ordenamentos jurídicos contemporâneos buscam alargar o dever de indenizar, a fim de restarem cada vez menos danos irressarcidos, posto ser a questão da reparabilidade do dano essencial para a tranquilidade social, revendo conceitos e requisitos da responsabilidade civil, tais como os de causalidade e de dano.

O campo da responsabilidade civil, portanto, evoluiu de forma a expandir os danos suscetíveis de reparação e a ampliar o rol de lesados, vigorando hoje o princípio de que todo dano

\footnotetext{
${ }^{202}$ VILLELA, João Baptista. Para além do lucro e do dano: efeitos sociais benéficos do risco. Repertório IOB de Jurisprudência, São Paulo, n. 22, cad. 3, nov. 1991, p. 490.

203 NORONHA, Fernando. Desenvolvimentos Contemporâneos da Responsabilidade Civil. Revista dos Tribunais, São Paulo, ano 88, v. 761, p. 32-35, mar. 1999.

${ }^{204}$ HIRONAKA, Giselda Maria Fernandes Novaes. Responsabilidade pressuposta. Evolução de fundamentos e de paradigmas da responsabilidade civil na contemporaneidade. In: DELGADO, Mário Luiz; ALVES, Jones Figueirêdo (Coord.). Questões Controvertidas no Novo Código Civil, v. 5, p. 198.
} 
injusto deve ser ressarcido e de que toda pessoa que sofra uma lesão deve tê-la reparada. Tal princípio é ressaltado, inclusive, pela Constituição Federal de 1988, que trouxe a possibilidade de compensação dos danos morais, também chamados de danos não patrimoniais, ampliando as hipóteses de reparabilidade e reforçando a ideia de que onde há dano há reparação.

Nesse aspecto, a doutrina e a jurisprudência muito contribuíram para essa evolução, mas a verdadeira mudança partiu da sociedade, dada a maior conscientização que as pessoas passaram a ter quanto à sua dignidade, exigindo respeito e buscando a reparação de qualquer mal injustamente sofrido. Se antes o olhar estava voltado para a conduta do autor do dano, hoje observa-se o lado da vítima, ${ }^{205}$ e a evolução da responsabilidade civil aponta para a necessidade de socorrê-la.

Nesta linha de pensamento é que se evidencia a questão do nascituro, cuja natureza jurídica tem sido fruto de grande discussão doutrinária e divergência jurisprudencial. Como consequência de ser o nascituro considerado pessoa, ter-se-á a possibilidade de integral reparação do dano sofrido por ele, de forma a acompanhar a evolução do instituto da responsabilidade civil bem como os ditames civis e constitucionalistas de valorização e respeito do ser humano enquanto tal.

É importante observar, ainda, que, mesmo que não se reconheça a qualidade de pessoa do nascituro, a legislação pátria lhe atribui, expressamente , alguns direitos e a doutrina e jurisprudência atuais, outros tantos, ${ }^{206}$ devendo qualquer lesão que lhe for causada ser reparada com fundamento no sistema de responsabilidade civil ou penal.

O reconhecimento da qualidade de pessoa do nascituro implicará, assim, importante avanço em direção às diretrizes atuais de valorização do ser humano, uma vez que terá por consequência a proteção dos direitos da personalidade - que também devem ser atribuídos e garantidos ao nascituro tal como a qualquer ser humano em qualquer de suas fases de desenvolvimento -, bem como a possibilidade de reparação civil por dano causado ao próprio nascituro.

\footnotetext{
${ }^{205}$ PEREIRA, Caio Mário da Silva. Instituições de Direito Civil. v. 3. 13. ed. Rio de Janeiro: Forense, 2009. p. 486.

${ }^{206}$ Como exemplo, podemos citar o direito a alimentos, reconhecido ao nascituro antes mesmo da Lei de Alimentos Gravídicos, conforme se verifica na RT 650/220; ou então, a possibilidade de adoção do nascituro, conforme assinalado por Silmara Juny de Abreu Chinellato em "Adoção de nascituro e a quarta era dos direitos: razões para alterar o caput do artigo 1.621 do novo Código Civil”. In: DELGADO, Mário Luiz; ALVES, Jones Figueirêdo (Coord.). Questões Controvertidas no novo Código Civil, v. 1, p. 355.
} 
De modo a sustentar a inviabilidade da ausência de tutela civil ao nascituro por ser contrário aos ditames atuais do instituto e por ir contra o fundamento maior da República Federativa do Brasil, que é a proteção e valorização da dignidade humana, faz-se necessária uma breve apresentação da evolução do instituto da responsabilidade civil e de seus princípios, explanando os tipos de danos possíveis, até chegar aos danos passíveis de serem causados ao nascituro, bem como a necessidade de sua reparação e o tratamento dado ao assunto pelos tribunais brasileiros.

\subsection{A Evolução do Instituto da Responsabilidade Civil}

O estudo da responsabilidade civil tem seu ponto de partida numa época em que vigia a vingança privada. A vingança privada foi a forma de repressão do dano adotada por todos os povos em sua origem e que, nas palavras de Alvino Lima, seria a "forma primitiva, selvagem talvez, mas humana, da reação espontânea e natural contra o mal sofrido”. 207

Num segundo momento, o poder de repressão que se encontrava no âmbito privado passa para as mãos do Estado, mas o poder público pouco muda sua forma de reação ao dano, apenas intervindo no sentido de regular os casos em que a reparação do mal pelo mal era ou não justificável, por meio da pena de Talião, do “olho por olho, dente por dente”, encontrada na Lei da XII Tábuas.

Com o tempo, percebe-se a vantagem da reparação econômica do dano, segundo a qual o lesado, a seu critério, receberia um resgate, na forma de soma em dinheiro ou na entrega de objetos, o que aparece primeiro sob a forma de composição voluntária a critério da vitima, passando a contar com a ajuda da força coercitiva do Estado, por meio da chamada composição tarifada, na qual o valor da pena, em alguns casos concretos, era pré-fixado. Mas embora não houvesse ainda um princípio geral orientador da responsabilidade civil, deu-se, de maneira definitiva, a substituição da vingança privada pela composição obrigatória. ${ }^{208}$

\footnotetext{
${ }^{207}$ LIMA, Alvino. Culpa e Risco. São Paulo: Revista dos Tribunais, 1998. p. 19.

208 Ibidem, p. 20-21.
} 
Entretanto, ainda não se vislumbrava uma reparação com caráter de reparação civil propriamente dita, tal como conhecemos, mas sim de pena. A distinção entre pena e reparação surgiu apenas ao tempo do Direito Romano, com a distinção de delitos públicos e delitos privados, assumindo o Estado, pouco a pouco, além da função de punir, também a função repressiva, surgindo a ação de indenização e a responsabilidade civil. ${ }^{209}$

É com a Lei Aquília que o Direito Romano constrói a estrutura jurídica da responsabilidade civil extracontratual, estabelecendo um princípio geral regulador da reparação do dano, substituindo as penas fixas pela pena de reparação pecuniária do dano sofrido, tendo em vista o valor da coisa, com a aplicação do damnum injuria datum, trazendo também a noção de culpa como requisito do direito de reparação do dano. ${ }^{210}$

Mas o estudo da responsabilidade civil como instituto é algo contemporâneo, que surgiu pela primeira vez no final do século XVIII. ${ }^{211}$ Pode-se afirmar que com o Código Civil de Napoleão, finalmente, se proclamou nitidamente um princípio geral de responsabilidade civil, estabelecendo-se a noção de culpa em abstrato e a distinção entre culpa delitual e culpa contratual. $^{212}$

A teoria clássica desenvolvida no Direito Romano e aprimorada pela jurisprudência francesa dos séculos XVIII e XIX assentou a responsabilidade civil em três pressupostos - a existência de dano, a culpa e o nexo causal entre a conduta culposa e a ocorrência do dano -, dando origem ao que hoje se convencionou chamar de responsabilidade subjetiva. Para a teoria clássica, portanto, a prova da culpa verificava-se como fundamento necessário do dano indenizável. ${ }^{213}$

No entanto, com o surto industrial do pós-Guerra e a introdução de processos mecânicos nos meios de produção, aumentaram o número de acidentes, gerando uma situação em que os operários restavam desamparados diante da impossibilidade de comprovar a culpa do patrão e revelando a insuficiência da noção da culpa como fundamento da responsabilidade, o que motivou a difusão dos estudos existentes quanto a responsabilidade civil. Primeiro sugeriu-se a inversão do ônus da prova, caminhando depois, a partir da metade do século XIX, por influência

\footnotetext{
${ }^{209}$ GONÇALVES, Carlos Roberto. Direito Civil Brasileiro, v. 4, p. 6-7.

${ }^{210}$ LIMA, Alvino. Culpa e Risco, p. 22.

${ }^{211}$ Nas palavras de Sílvio de Salvo Venosa: “o instituto da responsabilidade civil é algo contemporâneo, pois surge pela primeira vez no final do século XVIII, no âmbito do direito revolucionário francês”. VENOSA, Sílvio de Salvo. Direito Civil: Responsabilidade Civil. 5. ed. São Paulo: Atlas, 2005. p. 14.

${ }^{212}$ GONÇALVES, Carlos Roberto. Op. cit., v. 4, p. 8.

213 Ibidem, p. 6.
} 
da doutrina italiana e, principalmente, francesa, para o desenvolvimento da responsabilidade objetiva com base na teoria do risco. ${ }^{214}$

Caio Mário explicitou essa realidade ao aduzir que “deixado à vítima o ônus da prova de que o ofensor procedeu antijuridicamente, a deficiência de meios, a desigualdade de fortuna, a própria organização social acabam por deixar larga cópia de danos descobertos sem indenização". ${ }^{215}$

A teoria da responsabilidade objetiva, sem substituir a teoria da culpa, veio, ao contrário, complementá-la, cobrindo muitas hipóteses em que esta se mostrava insuficiente para a proteção da vítima.

Se antes o fundamento da responsabilidade era buscado no agente provocador do dano, não havendo responsabilidade sem culpa, ${ }^{216}$ passou-se a buscar o ideal de que todo dano deve ser indenizado, mudando o olhar da responsabilidade civil para a vítima e o dano em si mesmo, podendo o fundamento da responsabilidade também ser encontrado no exercício de atividades perigosas como também no próprio fato da coisa. ${ }^{217}$

No Brasil, a teoria da responsabilidade objetiva já havia sido contemplada em alguns artigos do Código Civil de 1916, bem como em várias leis especiais, ${ }^{218}$ mas somente com o Código Civil de 2002 admitiu-se a existência de um princípio geral da responsabilidade objetiva ao lado da responsabilidade subjetiva. ${ }^{219}$

Atualmente, a doutrina aponta "tendências da responsabilidade civil”, de modo que a reparação proporcionada às pessoas seja a mais abrangente possível. Fernando Noronha aponta três tendências, quais sejam, os por ele denominados de fenômenos: (i) da expansão dos danos suscetíveis de reparação, (ii) da objetivação da responsabilidade e (iii) sua coletivização. ${ }^{220}$

A primeira tendência seria, portanto, a expansão dos danos indenizáveis. Hoje falamos em duas categorias de danos, o patrimonial e o moral. A Constituição Federal trouxe em seu

\footnotetext{
${ }^{214}$ GOMES, Orlando. Obrigações. Rio de Janeiro: Forense, 1998. p. 373.

${ }^{215}$ PEREIRA, Caio Mário da Silva. Instituições de Direito Civil, v. 3, p. 486.

${ }^{216}$ Vigorava o brocado "pas de responsabilité sans faute".

${ }^{217}$ GONÇALVES, Carlos Roberto. Direito Civil Brasileiro, v. 4, p. 12.

${ }^{218}$ Nesse sentido, cf. Decreto n. 2.681/1912, que trata da responsabilidade civil das estradas de ferro. Cf., também, leis que disciplinam o acidente do trabalho; Lei federal n. 6.453/1977, que regulamenta a responsabilidade civil por dano nuclear; Lei ambiental n. 6.938/1981; Código de Defesa do Consumidor; Estatuto do Torcedor (Lei federal n. 10.671/2003); e, atualmente, a Lei de Biossegurança (Lei federal n. 11.105/2005).

${ }^{219}$ HIRONAKA, Giselda Maria Fernandes Novaes. Responsabilidade pressuposta. Evolução de fundamentos e de paradigmas da responsabilidade civil na contemporaneidade, p. 209.

${ }^{220}$ NORONHA, Fernando. Desenvolvimentos Contemporâneos da Responsabilidade Civil, p. 35.
} 
corpo a previsão expressa da reparação por dano moral, ${ }^{221}$ e, antes dela, já podíamos verificar a existência do dano moral na legislação especial, tal como a Lei de Direito Autoral (Lei federal n. 5.988/73), bem como na doutrina, conforme pode ser verificado no livro pioneiro de Yussef Said Cahali, Dano e Indenização (1981), e na obra de Carlos Alberto Bittar, Reparação Civil por danos morais (1998). ${ }^{222}$

Mas não apenas com o dano moral verificamos o fenômeno da expansão do rol dos danos indenizáveis. Hoje, já se falam em danos transindividuais coletivos e difusos, que podem ser encontrados no Código de Defesa do Consumidor (artigos $6^{\circ}$, inciso VI, e 81). Antônio Junqueira de Azevedo, por sua vez, faz menção a um novo tipo de dano ao lado do dano moral e do dano patrimonial, qual seja, o dano social. Este dano, para o autor, consiste no "ato doloso ou gravemente culposo” ou "negativamente exemplar”, que não é lesivo só ao patrimônio moral ou material da vítima, mas atinge toda a sociedade. ${ }^{223}$ Também podemos citar os danos punitivos (punitive damages). Eles se referem a casos que afetam toda uma sociedade. As indenizações por danos punitivos representam uma quantia enorme, pois se quer condenar a atitude de um indivíduo. Nos países europeus e norte-americanos, geralmente, o valor auferido em razão da reparação de um dano punitivo vai para um fundo. No Brasil o dano punitivo não existe sozinho, constituindo uma das facetas do dano moral. Entra no quantum do dano moral, não sendo uma categoria própria, nem equivalendo ao dano moral. Portanto, o valor relativo à reparação do dano punitivo em nosso país é destinado à parte processual. ${ }^{224}$ Podemos ainda citar a indenização pela perda de uma chance. ${ }^{225}$ Ainda pode ser citada tese de Teresa Ancona Lopez, que, embora entenda ser o dano estético uma forma de dano moral, defende ser possível a indenização pelo

\footnotetext{
${ }^{221}$ Cf. artigo $5^{\circ}$, incisos V e X, da Constituição Federal.

${ }^{222}$ CHINELLATO, Silmara Juny de Abreu. Tendências da Responsabilidade Civil no Direito Contemporâneo: reflexos no Código de 2002. In: DELGADO, Mário Luiz; ALVES, Jones Figueirêdo. Questões Controvertidas no Novo Código Civil, v. 5, p. 584.

${ }^{223}$ AZEVEDO, Antônio Junqueira de. Por uma nova categoria de dano na responsabilidade civil, In: FILOMENO, José Geraldo Brito; WAGNER JÚNIOR, Luiz Guilherme da Costa; GONÇALVES, Renato Afonso (Coord.). Código Civil e sua interdisciplinaridade: os reflexos do Código Civil nos demais ramos do Direito. Belo Horizonte: Del Rey, 2004. p. 374. Como exemplo de dano social, Azevedo cita a infração à obrigação de segurança (segurança de vida e de integridade física e psíquica) ou a situação de quebra da confiança em situações contratuais ou para-contratuais, devendo o ressarcimento ir para a parte.

${ }^{224}$ Nesse sentido, cf. LOURENÇO, Paula Meira. A função punitiva da Responsabilidade Civil, Coimbra: Coimbra Editora, 2006.

${ }^{225}$ SILVA, Rafael Peteffi da. Responsabilidade Civil pela perda de uma chance: comparação jurídica e direito positivo para um modelo dogmático brasileiro, 2004. Tese de Doutorado em Direito pela Universidade de São Paulo.
} 
dano estético de forma autônoma ao dano moral, sendo possível, inclusive, a cumulação de ambos. $^{226}$

Nessa linha de expansão dos danos indenizáveis encontramos a possibilidade de indenização ao nascituro por danos pré-natais. ${ }^{227}$ Inclusive, observa-se essa tendência na jurisprudência, como nos casos de uso da talidomida durante a gestação, em que tem sido concedida indenização pelos danos pré-natais causados. A jurisprudência brasileira negava peremptoriamente os danos pré-natais, mas a partir da década de 1960 passou a reconhecê-los podendo-se atribuir tal mudança de entendimento às contribuições da Bioética no campo da responsabilidade civil.

Uma segunda tendência é a objetivação da responsabilidade civil. Hoje, como visto, falamos não só em responsabilidade subjetiva, mas também em responsabilidade objetiva, tendo o Código Civil atual contemplado um sistema geral de responsabilidade fundamentado no risco ao lado de um sistema geral de responsabilidade fundamentado na culpa. ${ }^{228}$ Mas é importante verificar que, embora a responsabilidade civil tenha caminhado para a objetivação, a responsabilidade subjetiva não desapareceu, convivendo ambas harmoniosamente. ${ }^{229}$

A terceira tendência é a coletivização da reparação civil, ou seja, a coletivização da cobertura social dos danos, com base em fundos públicos, como por exemplo, por meio do seguro de responsabilidade civil ${ }^{230}$ ou pelo desenvolvimento da seguridade social. Tal tendência coincide com a pretensão de oferecer cobertura a todos os danos sociais. ${ }^{231}$

Silmara Chinellato aponta uma quarta tendência - a do alargamento do rol dos titulares ativos e passivos, lesantes e lesados. ${ }^{232}$ Nesse sentido, podem causar dano a terceiros: pessoas naturais, pessoas jurídicas, entes não personalizados; e podem ser indenizadas: pessoas naturais (nascidas ou o nascituro), pessoas jurídicas, os mortos e comunidades.

\footnotetext{
${ }^{226}$ LOPEZ, Teresa Ancona. O dano estético: responsabilidade civil. 3. ed. São Paulo: Revista dos Tribunais, 2004. p. 163.

${ }^{227}$ Nesse sentido, cf. CHINELLATO, Silmara Juny de Abreu. O nascituro perante os Tribunais: A recente decisão do Tribunal de Justiça de São Paulo. Evolução e tendências. Revista do Advogado, São Paulo, n. 20, p. 222-230, jul./dez. 2007.

${ }^{228}$ HIRONAKA, Giselda Maria Fernandes Novaes. Responsabilidade pressuposta. Evolução de fundamentos e de paradigmas da responsabilidade civil na contemporaneidade, p. 201.

${ }^{229}$ CHINELLATO, Silmara Juny de Abreu. Tendências da Responsabilidade Civil no Direito Contemporâneo: reflexos no Código de 2002, p. 597.

${ }^{230}$ Como exemplo, podemos citar o seguro obrigatório para veículos terrestres automotores - DPVAT.

${ }^{231}$ Nesse sentido, cf. MORSELLO, Marco Fábio. Responsabilidade Civil no transporte aéreo. São Paulo: Atlas, 2006.

${ }^{232}$ CHINELLATO, Silmara Juny de Abreu. Tendências da Responsabilidade Civil no Direito Contemporâneo: reflexos no Código de 2002, p. 589.
} 
De todo o exposto, chegamos à conclusão de que atualmente a responsabilidade civil é a regra e a irresponsabilidade civil, a exceção; sendo este um novo princípio geral a se observar.

\subsection{Dano e Reparação}

Abre-se aqui um subitem para tratar brevemente do dano, de modo a entender melhor o dano passível de ser causado ao nascituro e como isso tem sido tratado na doutrina e na jurisprudência pátria.

O dano pode ser conceituado como qualquer lesão sofrida por um bem jurídico, que pode ou não ter caráter patrimonial. Esta definição já era trazida por Agostinho Alvim, que definiu o dano em sentido amplo como sendo: “a lesão de qualquer bem jurídico”, incluindo no conceito de dano, portanto, o dano moral. ${ }^{233}$

Segundo a doutrina, é possível distinguir o dano em duas categorias, levando em conta seus efeitos: de um lado, a categoria dos danos patrimoniais e, de outro, a dos danos morais. ${ }^{234}$ Os danos patrimoniais abrangem os casos em que o bem atingido faz parte do patrimônio da vítima, contendo valor econômico definível, podendo ser, via de regra, reparado através de prestação pecuniária. ${ }^{235}$ Os danos morais, por sua vez, podem ser conceituados como as lesões sofridas pela pessoa em certos aspectos de sua personalidade em razão de investidas injustas de outrem. ${ }^{236}$

Mas embora seja esse o entendimento consagrado pela doutrina atualmente, nem sempre foi assim. O reconhecimento do dano moral como indenizável passou por larga evolução. Nesse sentido, em comparação à responsabilidade civil subjetiva, que dada às pressões e as necessidades sociais abriu espaço à responsabilidade civil objetiva, também a reparabilidade do dano moral foi sendo reconhecida face à aceitação exclusiva do dano patrimonial. ${ }^{237}$

\footnotetext{
233 ALVIM, Agostinho. Da inexecução das obrigações e suas consequências. 5. ed. São Paulo: Saraiva, 1980. p. 171-172. Cabe aqui a ressalva de que Agostinho Alvim, assim como outros autores, tais como Orlando Gomes, se filiava à doutrina que aceitava a reparabilidade do dano moral, embora entendesse que nosso Direito, anteriormente à Constituição Federal de 1988, não a havia adotado como princípio geral.

${ }^{234}$ CAHALI, Yussef Said. Dano Moral. 3. ed. São Paulo: Revista dos Tribunais, 2005. p. 20.

${ }^{235}$ VENOSA, Sílvio de Salvo. Direito Civil: Responsabilidade Civil, p. 43.

${ }^{236}$ BITTAR, Carlos Alberto. Danos Morais: critérios para sua fixação. Boletim IOB, n. 15/93, ago. 1993, p. 293.

${ }^{237}$ CAHALI, Yussef Said. Op. cit., p. 19.
} 
Fazendo uma breve referência à evolução histórica do reconhecimento do dano moral, podemos dizer que antes da Constituição Federal de 1988, embora já despontasse na doutrina o reconhecimento da reparação civil por dano moral, ainda se encontrava alguma relutância em nossa jurisprudência, que se recusava a indenizar tal dano sob o argumento de que não seria possível quantificar um valor para a dor. Defendia-se que o Código Civil de 1916 não trazia regra geral de reparação do dano moral, embora já trouxesse algumas hipóteses em artigos esparsos, e que apenas reconhecia o direito à indenização nos casos expressamente previstos. Mesmo assim, para alguns, a reparação somente era possível se do dano moral decorresse prejuízo econômico. $^{238}$

Tanto a doutrina quanto a jurisprudência brasileira, portanto, caminharam no sentido de reconhecer o dano moral, principalmente após 1988, de modo que do não reconhecimento do dano moral como dano indenizável e autônomo, passou-se ao reconhecimento da reparação por dano moral, bem como admitiu-se a possibilidade da cumulação com o dano patrimonial. ${ }^{239}$

Nesse sentido, verificar na doutrina a evolução para o reconhecimento do dano moral. Na obra original de Orlando Gomes, Obrigações, o autor traz o conceito de dano como sendo "a lesão que sofre um patrimônio”, mas complementa-o, já apontando a tendência em se reconhecerem danos não patrimoniais, aduzindo que:

\begin{abstract}
a lesão pode consistir na violação de direitos extrapatrimoniais, como são os personalíssimos, não causando, portanto, dano, propriamente dito, a menos que afete, por via de consequência, o patrimônio. Contudo, desenvolve-se tendência para considerar plausível um dano moral ao lado do dano material, que é eminentemente patrimonial. Por isso, escritores modernos definem o dano como a diminuição ou subtração de um bem jurídico. ${ }^{240}$
\end{abstract}

Nos nossos tribunais, a decisão pioneira no sentido de reconhecer a possibilidade de reparação do dano moral, conforme assinala Cahali, foi do Tribunal de Justiça do Rio Grande do $\mathrm{Sul}^{241}$ e a esta se seguiram muitas outras, até culminarmos com o fim das dúvidas quanto à

\footnotetext{
${ }^{238}$ CAHALI, Yussef Said. Dano Moral, p. 49-52.

${ }^{239}$ A Constituição Federal trouxe a previsão do dano moral em seu artigo 5o, incisos $\mathrm{V}$ e $\mathrm{X}$, dirimindo quaisquer dúvidas; e o Superior Tribunal de Justiça sumulou a possibilidade de cúmulo do dano moral com o patrimonial, cf. Súmula 37: "São cumuláveis as indenizações por dano material e dano moral oriundos do mesmo fato".

${ }^{240}$ GOMES, Orlando. Obrigações, p. 363. Cabe ressalvar que Orlando Gomes reconheceu em tese a existência de do dano moral, mas não a vislumbrava como existente em nosso ordenamento pátrio, tendo em vista o Código Civil de 1916.

${ }^{241}$ CAHALI, Yussef Said. Op. cit., p. 20. Cf., também, RJTJRS 64/198.
} 
reparabilidade ou não dos danos morais com a previsão expressa em texto constitucional da possibilidade de reparação do dano moral. ${ }^{242}$

A Constituição Federal de 1988, portanto, pondo fim a qualquer discussão, assegurou definitivamente o princípio da reparação do dano moral, e assim foi seguida pela legislação infraconstitucional, conforme previsões no Código de Defesa do Consumidor, no Estatuto da Criança e do Adolescente e conforme se verificou com a entrada em vigor do Código Civil de 2002.

Dessa forma, modernamente, restam consolidados, indiscutivelmente, na doutrina, na jurisprudência e, agora, por previsão expressa na lei, duas modalidades de dano: ${ }^{243}$ o dano patrimonial, consistente naquele que afeta o patrimônio da vítima, e o dano moral, como sendo aquele que ofende a vítima enquanto ser humano. ${ }^{244} \mathrm{E}$ a importância do reconhecimento do dano moral como dano indenizável se fundamenta na teoria da ampla reparação, da reparação de todo e qualquer dano civil, ocorrendo ele no patrimônio ou na esfera da personalidade da vítima. Conforme salienta Humberto Theodoro Júnior, "há de indenizar o ofendido todo aquele que cause um mal injusto a outrem, pouco importando a natureza da lesão”. 245

O dano moral, difere dos danos patrimoniais, pois diz respeito à esfera pessoal da vítima, que é atingida em valores fundamentais (tais como integridade física, saúde, reputação, a própria vida, danos estéticos, sociais e todos os direitos da personalidade, entre outros). Hoje, ao conceito de dano moral é dada cada vez mais abrangência, não se considerando apenas os prejuízos de ordem sentimental do homem, por atingirem direitos da personalidade.

Embora muitos autores ${ }^{246}$ adotem o conceito de dano moral a contrario sensu, como sendo o dano não patrimonial, a distinção de dano patrimonial e dano moral reside não na qualidade do direito subjetivo afetado, mas sim nos efeitos da lesão jurídica. Nesse sentido, Yussef Said Cahali adota um conceito de dano moral pautado em seus próprios elementos, de forma a sugerir um princípio geral do dano moral, aduzindo que "tudo aquilo que molesta gravemente a alma humana, ferindo-lhe gravemente os valores fundamentais inerentes à sua

\footnotetext{
${ }^{242}$ Cf. art. $5^{\circ}$, incisos V e X, da Constituição Federal.

243 Azevedo, como visto, fala em três tipos de dano: dano patrimonial, dano moral e dano social. AZEVEDO, Antônio Junqueira de. Por uma nova categoria de dano na responsabilidade civil, passim.

${ }^{244}$ GONÇALVES, Carlos Roberto. Direito Civil Brasileiro, p. 338.

${ }^{245}$ CAHALI, Yussef Said. Dano Moral, p. 05.

${ }^{246}$ Cf., por exemplo, GOMES, Orlando. Obrigações. Cf., também, DIAS, José de Aguiar. Da Responsabilidade Civil. 11. ed. Rio de Janeiro: Renovar, 2006.
} 
personalidade ou reconhecidos pela sociedade em que está integrado, qualifica-se, em linha de princípio, como dano moral”. 247

Nesse sentido, também Carlos Alberto Bittar traz:

Qualificam-se como morais os danos em razão da esfera da subjetividade, ou do plano valorativo da pessoa na sociedade, em que repercute o fato violador, havendo-se, portanto, como tais aqueles que atingem os aspectos mais íntimos da personalidade humana (o da intimidade e da consideração pessoal), ou o da própria valoração da pessoa no meio em que vive e atua (o da reputação ou da consideração social). ${ }^{248}$

Logo, o dano moral em sentido amplo deve ser entendido como todo dano não patrimonial. Mas em sentido estrito, deve ser visto de modo relacionado com os direitos da personalidade, como uma diminuição da subjetividade da pessoa, derivada da lesão a um interesse espiritual. ${ }^{249}$

Ainda podemos citar Miguel Reale, que divide o dano moral em objetivo e subjetivo. Dano moral objetivo é o que "atinge a dimensão moral da pessoa no meio social em que vive, envolvendo o de sua imagem" e dano moral subjetivo "se correlaciona com o mal sofrido pela pessoa em sua subjetividade, em sua intimidade psíquica”. 250

Outra classificação do dano, distinta daquela que leva em conta os efeitos da lesão, mas que se refere à pessoa atingida pelo dano, é a de dano direto ou dano reflexo (ou ricochete). ${ }^{251}$ Tem-se dano direto quando a lesão é suportada pela própria vítima, e dano reflexo quando uma pessoa sofre por reflexo os efeitos da lesão de um dano causado a outrem. ${ }^{252}$ Dano reflexo ou em ricochete ocorre, portanto, quando o prejuízo atinge reflexamente pessoa ligada à vítima direta da atuação ilícita. Trata-se do dano causado pela interrupção de pagamento de pensão alimentícia em virtude de morte, dolosa ou culposa, sofrida por outrem. ${ }^{253}$

Ainda, apenas a título de observação, há que se constatar que o dano reflexo (ou dano indireto, conforme Carlos Alberto Bittar) não se confunde com dano moral indireto, que é o que decorre de um dano patrimonial.

\footnotetext{
${ }^{247}$ CAHALI, Yussef Said. Dano Moral, p. 22.

${ }^{248}$ BITTAR, Carlos Alberto. Reparação Civil por danos morais, p. 45.

${ }^{249}$ OLIVEIRA, Euclides Benedito de. Indenização por danos morais ao nascituro, p. 146.

${ }^{250}$ REALE, Miguel. Temas de Direito Positivo. São Paulo: Revista dos Tribunais, 1992. p. 23.

251 Deve-se tomar cuidado com a terminologia. Carlos Alberto Bittar (Reparação Civil por Danos Morais), faz referência a dano reflexo ou em ricochete da doutrina francesa utilizando-se também do termo "dano indireto".

252 GONÇALVES, Carlos Roberto. Direito Civil Brasileiro. v. 4, p. 339.

${ }^{253}$ PEREIRA, Caio Mário da Silva. Responsabilidade Civil. Rio de Janeiro: Forense, 1999. p. 43.
} 
A importância do estudo do dano e de suas classificações se dá tendo em vista a forma de reparação do mal. Conforme o dano seja patrimonial ou moral, a reparação do mesmo se dará por ressarcimento ou compensação. E sendo o dano direto ou reflexo, ter-se-ão diferentes titulares do direito à indenização, bem como diferentes quantificações.

Certo é que, havendo dano, seja patrimonial ou moral, é devida indenização pelo causador do mesmo, comprovada sua culpa quando necessário ou dispensada a prova desta nas hipóteses previstas em lei, devendo ressarcir o prejuízo no caso de dano patrimonial, abrangendo o dano emergente e os lucros cessantes, ou reparando o dano de forma a compensá-lo, quando moral. $^{254}$

Tendo em vista essas ideias gerais, pode-se afirmar que hoje a responsabilidade civil se destina a restaurar o equilíbrio patrimonial e moral, compensando ou ressarcindo o dano e, quando possível, voltando ao statu quo ante.

Mas quem pode ser titular da pretensão indenizatória, por danos patrimoniais ou morais? É nesse sentido que se enquadra a importância do estudo do dano para o nascituro, conforme será verificado no item subsequente.

\subsection{A Personalidade Civil do Nascituro como Fundamento para Reparação}

Questão controvertida, ligada ao reconhecimento da personalidade do nascituro, referese à possibilidade de este ser vítima de dano moral ou patrimonial.

Para saber se pode o nascituro sofrer ou não lesão patrimonial ou moral, há que se enfrentar o problema de sua natureza jurídica. Sendo-lhe reconhecida a qualidade de pessoa, conforme visto, tem o nascituro, desde a concepção, direitos da personalidade e, portanto, possibilidade de sofrer lesão à mesma. Quanto aos direitos patrimoniais, mesmo para alguns dos defensores da teoria concepcionista, que entendem ser o nascituro pessoa desde a concepção, restariam seus efeitos condicionados resolutivamente ao nascimento, como, por exemplo, a

\footnotetext{
${ }^{254}$ Utiliza-se o termo reparação como gênero, sendo suas espécies o ressarcimento, que se refere ao dano patrimonial, e a compensação, que se refere ao dano moral. Cf. CAHALI, Yussef Said. Dano Moral, p. 43.
} 
doação e a herança. ${ }^{255}$ Tendo isso em vista, os danos patrimoniais que podem ser ocasionados ao nascituro enquanto tal, que não dependam de seu nascimento com vida, referem-se apenas aos danos patrimoniais reflexos dos danos a seus direitos da personalidade. Isso direciona nossos estudos, principalmente, ao debate sobre a personalidade do nascituro como fundamento para reparação por dano moral.

Isso posto, temos que, reconhecida a natureza humana do nascituro, não poderia ele sofrer lesão sem a devida reparação. Mas para que tal afirmação seja entendida como verdadeira, há primeiro que se reconhecer que o nascituro possui direitos da personalidade desde o momento da concepção de forma plena e não condicionada a outros fatores, tais como o nascimento com vida. Pois é no reconhecimento de direitos da personalidade do nascituro que vai ser fundamentada a possibilidade de reparação por lesões por ele sofridas.

O dano moral em sentido amplo há que ser entendido como qualquer lesão aos direitos da personalidade, podendo ou não ter reflexos patrimoniais. A possibilidade de o nascituro ser vítima do dano moral, portanto, se fundamenta no reconhecimento da personalidade do nascituro.

No que se refere aos danos morais, o titular da pretensão indenizatória é o titular de direitos da personalidade ou seus herdeiros. ${ }^{256}$

A doutrina, como não poderia deixar de ser, quando trata da possibilidade de reparação civil do nascituro, diverge. Humberto Theodoro Júnior refere-se à possibilidade de o nascituro ser titular do direito à indenização por dano moral, embora o autor entenda que o nascituro somente se torna pessoa após o nascimento com vida. Reconhece que, como a lei protege seus direitos (que entende serem eventuais) desde a concepção, é possível que fatos ocorridos durante a gestação tenham graves repercussões à sua personalidade após o nascimento com vida, devendo os danos serem, portanto, reparados. Nesse sentido, o autor se refere à decisão relatada pelo Juiz Adail Moreira, que reconheceu ao nascituro, sob a condição de nascer com vida, o direito a uma adequada indenização pela perda de seu genitor. ${ }^{257}$

Para Carlos Roberto Gonçalves, que entende estarem os direitos patrimoniais sujeitos ao nascimento com vida, sob condição suspensiva, não haveria que se falar, antes do acontecimento

\footnotetext{
${ }^{255}$ CHINELLATO, Silmara Juny de Abreu. Tutela Civil do nascituro, p. 169.

${ }^{256}$ O dano moral é transmissível, conforme já decidiu o Superior Tribunal de Justiça: “o direito de ação por dano moral é de natureza patrimonial e, como tal, transmite-se aos sucessores da vítima” (RSTJ, 71/183). E, conforme artigo 12, parágrafo único do Código Civil, em se tratando de morto, terá legitimação para reclamar perdas e danos por lesão a direitos da personalidade qualquer parente em linha reta, ou colateral até o $4^{\circ}$ grau.

${ }^{257} 2^{\circ}$ TACivSP, na Apelação n. 489.775-017. THEODORO JUNIOR, Humberto. Dano Moral. 3. ed. São Paulo: Revista dos Tribunais, 2005. p. 19.
} 
nascimento, em direitos patrimoniais. E como para o autor a ação de reparação por dano moral seria patrimonial, o nascituro somente poderia ajuizar, por seus representantes, medidas cautelares preventivas, visando à proteção de seus direitos da personalidade. Ações de ressarcimento ou reparação ficariam sujeitas à condição suspensiva do nascimento com vida. ${ }^{258}$

A crítica que pode ser feita a esse entendimento diz respeito ao fato de que, com esta solução, o autor do ato lesivo seria beneficiado em prejuízo do nascituro, não sendo dada a ampla reparação pelo dano; e isso com base no fundamento falacioso de que a ação de dano moral seria patrimonial. Embora a quantificação da ação de dano moral se traduza em pecúnia, ela visa compensar lesão a direito da personalidade e este não se condiciona a nenhum acontecimento, já que os direitos da personalidade são incondicionados. ${ }^{259}$

Em posição contrária aos autores supracitados, Silmara Juny de Abreu Chinellato defende ser “indenizável a morte do conceptus porque ele é pessoa, desde a concepção”. ${ }^{260}$

Nesse sentido, Euclides Benedito de Oliveira também entende que pode ser aplicada a responsabilidade civil por dano causado ao nascituro:

\footnotetext{
mostra-se admissível e pertinente, pois, a indenização por danos pré-natais, como na hipótese de pais que transmitam doenças através da concepção (sífilis, AIDS), de médicos ou hospitais que se conduzam inadvertidamente, provocando danos ao feto (por medicação inadequada, omissões no tratamento, transfusão de sangue contaminado etc.). Estará havendo, em tais circunstâncias, dano à vida ou à saúde do nascituro, passível de reparação dentro do princípio geral da culpa que informa a responsabilidade civil por ato ilícito. $^{261}$
}

No entanto, embora pesem tais entendimentos favoráveis ao nascituro,, poder-se-ia, ainda, argumentar que o mesmo não detém capacidade de entender o ato lesivo, sendo impossível, portanto, sofrer qualquer menoscabo espiritual. Conforme se vai verificar, entretanto, tal argumentação não merece amparo.

Antes mesmo de se estabelecer a natureza jurídica de pessoa do nascituro, poder-se-ia perguntar se existiria a possibilidade de um incapaz, tal como as crianças em tenra idade, os deficientes mentais sem capacidade de discernimento e até o nascituro, sofrer dano moral, já que incapaz seria este de entender o ato lesivo.

\footnotetext{
${ }^{258}$ GONÇALVES, Carlos Roberto. Direito Civil Brasileiro, v. 4, p. 366.

${ }^{259}$ CHINELLATO, Silmara Juny de Abreu. Tutela Civil do nascituro, p. 304.

${ }^{260}$ Idem. O nascituro no Código Civil e no Direito Constituendo do Brasil, p. 183.

${ }^{261}$ OLIVEIRA, Euclides Benedito de. Indenização por danos morais ao nascituro , p. 145.
} 
Antônio Jeová Santos entende que a incapacidade de compreensão do incapaz quanto ao menoscabo espiritual que lhe é imposto não afasta a possibilidade de que sofra dano moral, até para não livrar de reprovação um ato de pessoa que, voluntariamente, provocasse dano a um incapaz, expressando nesse sentido, ainda, que "não é porque alguém seja criança, demente ou está em coma, que perdeu os direitos da personalidade, ou que abriu mão do que há de mais importante no ser humano, que é a própria dignidade”. ${ }^{262}$

Nesse sentido, podemos acrescentar o entendimento de Maria Helena Diniz, que aduz que, para os desprovidos de discernimento, “o ressarcimento do dano não é considerado como a reparação do sentimento, mas como uma indenização objetiva de bem jurídico violado”. ${ }^{263}$

A configuração do dano moral, portanto, ocorre de maneira independente da possibilidade de a pessoa reunir ou não condições para entender o sofrimento ou o caráter lesivo do dano. O dano moral restaria configurado pela simples ofensa aos direitos da personalidade. E, conforme ressalva Antônio Jeová Santos, numa situação dessas, deve-se atentar para o fato de que nenhum fato ilícito e injusto deve ficar sem reparação, não podendo o ofensor se aproveitar da desvantagem da vítima. ${ }^{264}$

Especificamente a respeito do nascituro, Euclides de Oliveira, entende que:

da mesma forma que merece proteção jurídica o amental, a criança ainda na primeira fase de vida, ou aquele que esteja em vida comatosa, quando se lhes acarrete dano à personalidade, também enseja atenção o nascituro, em face do resguardo dos seus direitos desde a concepção. Não é porque lhe faltem sentimentos, ou capacidade para expressá-los, que possam vir a ser ofendidos em sua honra ou em outros aspectos de seu patrimônio pessoal. ${ }^{265}$

Antonio Jeová Santos, por sua vez aduz que

as crianças, os amentais, o nascituro e quem estiver inane, em vida vegetativa, são passíveis de sofrer dano moral. Não apenas a manifestação de dor, de angústia, de tristeza, ou o conhecimento que transmite ausência do desejo de viver são fatos demonstrativos de que alguém deixou de padecer dano moral e que, por isso, não será ressarcido, deixando seu ofensor livre para continuar na prática de outros agravos. ${ }^{266}$

\footnotetext{
${ }^{262}$ SANTOS, Antônio Jeová. Dano Moral Indenizável. São Paulo: Revista dos Tribunais, 2003. p. 125-127.

${ }^{263}$ DINIZ, Maria Helena. Curso de Direito Civil Brasileiro. v. 7, p. 253.

${ }^{264}$ SANTOS, Antônio Jeová. Op. cit., p. 128.

265 OLIVEIRA, Euclides Benedito de. Indenização por danos morais ao nascituro, p. 162.

${ }^{266}$ SANTOS, Antônio Jeová. Op. cit., p. 130. Ressalta-se que Antonio Jeová Santos entende que, enquanto o ser se encontra no claustro materno não poderá sofrer dano moral. Só há o dever de reparar no caso do nascituro sofrer uma lesão que se comprove após o seu nascimento com vida.
} 
Isso demonstra o entendimento de dano moral não mais apenas como uma lesão capaz de causar dor, sofrimento, mas sim como uma verdadeira lesão à personalidade.

Ultrapassada a quaestio quanto ao início da personalidade, e uma vez sendo o nascituro considerado pessoa, poderá ele ser indenizado por quaisquer danos por ele sofrido e, ainda, caso não nasça com vida, seus familiares poderão exigir a referida reparação, dada a transmissibilidade do dano moral. Se, no entanto, não for reconhecida ao nascituro a qualidade de pessoa, surgirá uma situação de extrema injustiça, principalmente por desrespeitar o princípio da igualdade, conferindo tratamento discriminatório pelo simples fato de o nascituro se encontrar em etapa diferente de evolução e desenvolvimento de sua vida. Além disso, aos ascendentes do nascituro restará apenas, e somente em alguns casos, indenização por direito moral próprio, afetando enormemente o quantum debeatur.

Desta monta, deve o artigo $2^{\circ}$ do Código Civil ser interpretado de acordo com todo o sistema por ele agasalhado e não isoladamente, de forma aos aplicadores do direito e os tribunais reconheçam ao nascituro sua personalidade jurídica, levando à máxima efetividade o princípio de que não deve haver dano sem a sua devida reparação, bem como o princípio constitucional da dignidade da pessoa humana.

\subsection{Dos Danos Causados ao Nascituro}

Tendo em vista a realização do atual escopo do sistema de responsabilidade civil pela mais ampla reparação é que se coloca a discussão da extensão da obrigação de indenizar e, neste aspecto, se encaixa a problemática dos danos possíveis de serem causados aos direitos do nascituro.

Mas, como visto, ainda não há consenso sobre a natureza jurídica do nascituro, muito menos em relação à consequente possibilidade de lesão a direitos do nascituro enquanto tal. Verificamos, portanto, neste ponto, e utilizando a colocação de Euclides Benedito de Oliveira, que ao falarmos em reparação civil por danos ao nascituro, põe-se em confronto a 
“responsabilidade pela mais ampla indenização moral e material, sempre que haja lesão a direito alheio” e o “conceito civilístico de personalidade”. ${ }^{267}$

A natureza de pessoa do nascituro e os reflexos para o sistema da responsabilidade civil, como já se pôde vislumbrar, é questão não somente acadêmica, mas também de grande importância prática, que tem rondado nossos tribunais e gerado grande insegurança, seja pelas poucas manifestações da doutrina ou pelas discrepantes decisões judiciais. Certo é que cada vez mais o tema instiga a busca de solução pelos juristas e a atualização das normas, de forma a harmonizá-las com a nova realidade tecnológica e a nova era do conhecimento humano, confirmando a proeminência do respeito ao ser humano como princípio orientador e fundamento da República Federativa do Brasil.

Enfim, após debate sobre a natureza jurídica do nascituro, após a análise das normas civilistas à luz do texto constitucional e dos tratados internacionais sobre os direitos a ele conferidos, após uma reflexão do nascituro como pessoa e de seus direitos da personalidade, bem como do panorama geral do sistema da responsabilidade civil, chega-se ao cerne deste trabalho, qual seja, a análise do nascituro à luz da responsabilidade civil. E para isso, traremos à baila o tratamento jurisprudencial no tema. Mas antes de serem analisados os danos em espécie conforme a jurisprudência atual, far-se-á uma breve exposição da evolução do tratamento jurisprudencial conferido ao nascituro.

Para tratarmos da evolução do tema da responsabilidade civil ligada ao nascituro, é inevitável fazer referência ao avanço da medicina na área biomédica, já que este ramo da ciência reabriu as discussões sobre por que não conferir personalidade ao ser humano em tal etapa de desenvolvimento.

Antes das descobertas científicas na área pré-natal, pouco se discutia sobre o nascituro ser envolto de mitos e mistérios. Então nada mais natural do que o não reconhecimento de personalidade jurídica ao desconhecido nascituro. Entretanto, com o avanço científico na área biológica, mesmo que em passos mais vagarosos, também ocorreram modificações nos entendimentos doutrinário e jurisprudencial no que diz respeito à reparação civil por lesão a direitos do nascituro.

Atualmente, se tem conhecimento exatamente de todas as etapas de desenvolvimento do ser humano, desde sua concepção - quando há a formação de um ser humano individualizado,

${ }^{267}$ OLIVEIRA, Euclides Benedito de. Indenização por danos morais ao nascituro, p. 145. 
representado por material biológico diferenciado - até a sua morte, tornando-se impossível negar um dado incontornável da ciência, qual seja, o de que o nascituro é ser humano em desenvolvimento.

É com base nessa contribuição científica que deve ser feita uma ligação entre a ciência e o conhecimento técnico-jurídico, fundamentado em preceitos éticos, humanistas e de valorização do ser humano, de forma a defender a necessidade de acolhimento do nascituro no sistema geral de responsabilidade civil.

Sob este aspecto e tendo em vista a ingerência do homem na vida desde seu momento inicial - seja acidentalmente, causando danos com reflexos ao longo de uma vida, seja intencionalmente, causando danos pré-natais -deve-se avaliar quais são as lesões possíveis de serem causadas ao nascituro.

Os tribunais brasileiros, no entanto, deixam a desejar no assunto, e apenas alguns poucos adotam uma interpretação mais progressista, admitindo a personalidade jurídica do nascituro e garantindo-lhe a possibilidade de indenização com base em tal fundamento:

SEGURO OBRIGATÓRIO. DANOS CAUSADOS POR VEÍCULOS
AUTOMOTORES DE VIAS TERRESTRES - DPVAT. EVENTO MORTE.
NASCITURO. JUNTADA CERTIDÃO DE DOCUMENTOS QUE DEMONSTRAM O
DEVER DE INDENIZAR. PAGAMENTO TOTAL. APLICAÇÃO DA SÚMULA 14
DAS TURMAS RECURSAIS CÍVEIS. O nascituro, porque provido de personalidade
jurídica desde o momento da concepção, também é sujeito da cobertura conferida pelo
seguro DPVAT, sendo devido o pagamento da indenização em caso de a interrupção da
gestação decorrente de acidente de trânsito. NEGARAM PROVIMENTO AO
RECURSO. (TJRS, Recurso Cível n. 71001157478 , Primeira Turma Recursal Cível,
Turmas Recursais, Relator: Heleno Tregnago Saraiva, Julgado em 12/04/2007). ${ }^{268}$

Em sua maioria, os julgados ainda se apresentam vacilantes e contraditórios quanto aos fundamentos para a indenização por dano causado ao nascituro, ora admitindo a possibilidade de indenização apenas após o nascimento (embora o ato lesivo tenha ocorrido antes), ora admitindo o dano à mãe e ora nem sequer admitindo a indenização.

Superado esse primeiro, porém, há que se enfrentar a questão dos danos possíveis de serem causados ao nascituro e sua reparação frente aos diferentes posicionamentos quanto a sua natureza jurídica.

Apenas fazendo uma ressalva inicial, o estudo da responsabilidade civil envolvendo o nascituro tem sido alvo de grandes novidades. Não mais envolve apenas polêmica sobre a questão

${ }^{268}$ Neste mesmo sentido: TJRS, Recurso Cível n. 71000611665; TJRS, Ap. Cív. n. 70002027910. 
indenizatória por atos lesivos à direitos da personalidade do nascituro, mas hoje inicia-se uma discussão, principalmente em países europeus, sobre a indenização pela ofensa ao direito de não nascer ou por um nascimento (vida) “errada”. 269

De forma a tornar a discussão da responsabilidade civil envolvendo o nascituro mais didática, passaremos à análise de cada hipótese por tópicos.

\subsubsection{Dano Moral Causado ao Nascituro}

Em sua grande monta, as lesões possíveis de serem causadas ao nascituro constituem danos à sua personalidade, a seus direitos de personalidade. Portanto, acarretam danos extrapatrimoniais, chamados pela doutrina de danos morais. O regime jurídico a ser adotado para a definição, a verificação e a quantificação da compensação do dano causado é o regime da responsabilidade civil, com base na Constituição Federal e, mais especificamente, no valor maior da dignidade da pessoa humana, por ser este princípio fundamento da tutela de quaisquer dos direitos da personalidade.

No campo da responsabilidade civil por danos morais, a violação de qualquer expressão da personalidade ou da dignidade da pessoa humana gera a obrigação de compensar o dano ${ }^{270} \mathrm{~A}$ lesão não pode ficar sem ser reparada e seu causador não deve sair impune. É esta a tendência da atualidade, segundo a qual todo dano deve ter sua reparação e a indenização por danos morais ao nascituro vem só reafirmar tal entendimento.

O dano moral, portanto, causado ao nascituro é o dano causado à sua personalidade. Protege-se aqui sua vida, sua integridade física e psíquica, sua honra, seu nome e sua imagem, entre outros possíveis danos à personalidade que se possam averiguar. São os chamados danos pré-natais.

No que diz respeito ao direito à vida, conforme alerta Silmara Chinellato, a situação danosa que acarreta a morte do nascituro pode configurar duas situações: (i) de indenização sob o fundamento da transmissibilidade do dano moral, para os defensores da tese da personalidade do

\footnotetext{
${ }^{269}$ Doutrinas intituladas de wrongful birth e wrongful life.

270 BORGES, Roxana Cardoso Brasileiro. Direitos de personalidade e dignidade: da responsabilidade civil para responsabilidade constitucional, p. 563.
} 
nascituro; e (ii) de indenização sob o fundamento de dano moral causado aos pais, como direito próprio, para os que não reconhecem a personalidade do nascituro. ${ }^{271}$

Reconhecer o direito do nascituro à vida implica reconhecer-lhe dignidade mínima e, mais importante, a qualidade de pessoa. E é como pessoa que o nascituro, respeitada as suas individualidades, deve ser encarado quando do estudo do sistema da responsabilidade civil.

Nesse sentido, Silmara Juny de Abreu Chinellato se posiciona lembrando que

no estágio atual de desenvolvimento da Ciência Jurídica nacional, na qual o instituto da responsabilidade civil e a doutrina dos direitos da personalidade ganham relevo cada vez maior, é inaceitável que se sustente que a morte do nascituro, ser humano em desenvolvimento, causada por ato ilícito, não seja passível de indenização civil, com postergação de seu direito à vida, em total descompasso com a progressiva indenização do dano material, inclusive por morte de animais. ${ }^{272}$

O Superior Tribunal de Justiça, por sua vez, tem decisão recente, de 2009, em que é categórico ao afirmar expressamente o direito à vida e à saúde do nascituro:

\begin{abstract}
PROCESSUAL CIVIL. GESTANTE. ESTADO CRÍTICO DE SAÚDE. AÇÃO CIVIL PÚBLICA. LEGITIMIDADE DO MINISTÉRIO PÚBLICO. DIREITO INDISPONÍVEL. 1. A demanda envolve interesse individual indisponível na medida em que diz respeito à internação hospitalar de gestante hipossuficiente, o que, sem sombra de dúvidas, repercute nos direitos à vida e à saúde do nascituro e autoriza a propositura da ação pelo Ministério Público. 2. "Tem natureza de interesse indisponível a tutela jurisdicional do direito à vida e à saúde de que tratam os arts. $5^{\circ}$, caput e 196 da Constituição, em favor de gestante hipossuficiente que necessite de internação hospitalar quando seu estado de saúde é crítico. A legitimidade ativa, portanto, se afirma, não por se tratar de tutela de direitos individuais homogêneos, mas sim por se tratar de interesses individuais indisponíveis" (REsp 933.974/RS, Rel. Min. Teori Albino Zavascki, DJU 19.12.07). 3. Agravo regimental não provido. (Ag. Rg. no REsp 1045750/RS, Rel. Ministro CASTRO MEIRA, SEGUNDA TURMA, julgado em 23/06/2009, DJe 04/08/2009)
\end{abstract}

O dano ao direito do nascituro à vida, seja por aborto provocado intencionalmente ou por acidente, enseja reparação civil com fundamento no dano moral, que é transmissível aos seus herdeiros. $^{273}$

De acordo com Yussef Said Cahali, o Direito pátrio passou por quatro estágios no que se refere à indenização por morte de filho, a saber: irreparabilidade do dano moral; ressarcibilidade

\footnotetext{
${ }^{271}$ CHINELLATO, Silmara Juny de Abreu. O nascituro perante os Tribunais: A recente decisão do Tribunal de Justiça de São Paulo, p. 226.

272 Idem. Tutela Civil do Nascituro, p. 4.

${ }^{273}$ Aos que não reconhecem a personalidade do nascituro, a morte do nascituro acarretaria dano aos pais, ou até a outras pessoas ligadas afetivamente ao nascituro, situação que vai ser analisada em item próprio. Neste item vai ser estudado apenas o dano à vida do nascituro como dano moral ao próprio nascituro, o qual é transmissível aos seus pais.
} 
em função dos reflexos patrimoniais imediatos (nos casos de filho menor que já trabalhava ou contribuía para o sustento da família; reparabilidade do dano, utilizando-se do artifício de divisar, no caso, a existência de dano patrimonial remoto, hipotético, potencial, futuro, eventual, ou reconhecimento da reparabilidade do dano moral pela morte de filho; e, por fim, a possibilidade de cumular dano moral e dano patrimonial. ${ }^{274}$

Silmara Juny de Abreu Chinellato afirma que nas décadas de 1960 e 1970 os Tribunais de Justiça não reconheciam a indenização por morte do nascituro. ${ }^{275}$ No entanto, a autora demonstra que há exemplos de julgados a partir da década de 1990 nos quais se observa a mudança jurisprudencial no sentido de reconhecimento de indenização pela morte do nascituro. Nesse sentido, a Apelação Cível n. 190.169-3, com relatoria de Juiz Tenisson Fernandes e julgada em 10 de maio de 1995 pelo Tribunal de Alçada de Minas Gerais, em que se concedeu indenização por dano moral em decorrência da morte do nascituro ${ }^{276}$; a Apelação Cível n. 2.804/95, com relatoria de Juiz Antonio Eduardo F. Duarte e julgada em 23 de junho de 1995 pelo Tribunal de Justiça do Rio de Janeiro, em que também se concedeu indenização por dano moral pela morte do nascituro ${ }^{277}$; e a Apelação Cível n. 70002027910, com relatoria do Desembargador Carlos Alberto Álvaro de Oliveira e julgada em 28 de março de 2001 pelo Tribunal de Justiça do Rio Grande do Sul, na qual foi concedida indenização pela morte do nascituro, mas como direito próprio do nascituro transmissível aos pais. ${ }^{278}$

\footnotetext{
${ }^{274}$ CAHALI, Yussef Said. Dano moral, p. 76.

275 CHINELLATO, Silmara Juny de Abreu. O nascituro perante os Tribunais. A recente decisão do Tribunal de Justiça de São Paulo, p. 224.

${ }^{276}$ Nascituro - Morte - Indenização por dano moral - Fixação - Aplicabilidade do Art. 1537/CC, II. Em indenização por dano moral decorrente da morte de feto, admissível a aplicação do art. 1.537, II, do CC, em analogia aos casos de homicídio praticado contra menor impúbere, considerando-se razoável o critério que estabelece o quantum indenizatório em número de salários mínimos correspondentes aos meses que mediariam entre o evento danoso e a data em que o nascituro completaria vinte e cinco anos de idade. (TA/MG, Ap. Cív. n. 190.169-3, Comarca de Governador Valadares, 3a. Câm. Cív., Rel. Juiz Tenisson Fernandes). Fonte: DJMG II, 03.08.95, p. 12. In BONIJURIS Jurisprudência - Cd-Rom - 24414).

${ }^{277}$ Atropelamento. Perda do nascituro. Responsabilidade objetiva. Indenização. A morte de um filho em gestação, não importa o motivo, toca profundamente a mulher em seu ponto mais sublime: a maternidade. Atinge um grau elevado na escala de valores morais. A brusca interrupção da gravidez constrange, causa dor e profundo sofrimento. Decorrente de ato ilícito, a perda do nascituro deve integrar o dano moral a ser reparado. (TA/RJ, Ap. Cív. n. 2.804/95, j. em 13.06.1995, Rel. Antonio Eduardo Ferreira Duarte).

${ }^{278}$ SEGURO-OBRIGATORIO. ACIDENTE. ABORTAMENTO. DIREITO A PERCEPÇAO DA INDENIZACAO . O NASCITURO GOZA DE PERSONALIDADE JURIDICA DESDE A CONCEPÇAO. O NASCIMENTO COM VIDA DIZ RESPEITO APENAS A CAPACIDADE DE EXERCICIO DE ALGUNS DIREITOS PATRIMONIAIS. APELACAO A QUE SE DA PROVIMENTO. (5 FLS.) (TJRS, Ap. Cív. n. 70002027910, Sexta Câmara Cível, j. em 28/03/2001, Rel. Carlos Alberto Alvaro de Oliveira).
} 
Yussef Said Cahali aduz que, quanto à morte de filho nascituro, a jurisprudência pátria tem enfrentado esse tema mais em sede de seguro obrigatório de responsabilidade civil automobilística (DPVAT). ${ }^{279}$

As principais questões que chegam aos tribunais envolvendo lesão à vida do nascituro dizem respeito, portanto, a casos de acidentes com veículos automotores. Trata-se de tema de grande relevância para o sistema da responsabilidade civil e com soluções controvertidas, envolvendo diretamente o reconhecimento ou não da qualidade de pessoa do nascituro, tendo em vista a possibilidade ou não de indenização pelo seguro obrigatório por acidentes de veículos automotores (DPVAT) pela morte do nascituro.

Yussef Said Cahali aponta que, quanto ao seguro obrigatório DPVAT, não era concedida indenização pela morte do filho nascituro. ${ }^{280}$ Nesse mesmo sentido, Silmara Chinellato alerta que até a década de 70 não se concedia indenização pela morte do nascituro. ${ }^{281}$ A verdade é que até meados da década de 80, a jurisprudência era vacilante até no que se refere a concessão de indenização por morte de filho menor já nascido, vez que até a Constituição de 88 ainda não restava consolidada a possibilidade de indenização por dano moral nos tribunais. No entanto, conforme se vai verificar, hoje vivencia-se uma mudança no entendimento jurisprudencial quanto a possibilidade de indenização por morte do nascituro.

O Tribunal de Justiça do Rio Grande do Sul, pioneiro no reconhecimento da possibilidade de concessão do seguro obrigatório no caso de morte do nascituro, tem decidido da seguinte forma:

\begin{abstract}
AÇÃO DE COBRANÇA. INDENIZAÇÃO DO SEGURO OBRIGATÓRIO DPVAT. NASCITURO. MORTE DECORRENTE DE ACIDENTE AUTOMOBILÍSTICO. 1. O nascituro, provido de personalidade jurídica desde o momento da concepção, está coberto pelo seguro DPVAT, visto que seu bem-estar é assegurado pelo ordenamento pátrio. É devido o pagamento da indenização no caso de interrupção da gravidez e morte causadas por acidente de trânsito. Precedentes das Turmas Recursais. 2. Aplicação da Súmula 14 das Turmas Recursais Cíveis, revisada em 24/04/2008. RECURSO IMPROVIDO. (Recurso Cível n. 71002287167, Terceira Turma Recursal Cível, Turmas Recursais, Relator: Eduardo Kraemer, Julgado em 15/10/2009). ${ }^{282}$
\end{abstract}

\footnotetext{
${ }^{279}$ CAHALI, Yussef Said. Dano moral, p. 133. Nesse sentido, considerando indevida a indenização: TAC SP RT563/129 (j. 19.05.1982); TJSP RT 525/70 (j. 19.12.1978); TAC SP RF 262/183 (j. 01.02.1977); Considerando devida a indenização: TJRS, Rec. Cív. 71001157478; TJRS, Rec. Cív. 71000611665 e Ap. Cív. 70002027910.

${ }^{280}$ CAHALI, Yussef Said. Op. cit., p. 76. Nesse sentido, ver também: RF 262/183, RT 525/70 E RT 563/129.

${ }^{281}$ CHINELLATO, Silmara Juny de Abreu. O nascituro perante os Tribunais. A recente decisão do Tribunal de Justiça de São Paulo, p. 226.

${ }^{282}$ Nesse sentido, o Tribunal de Justiça do Rio Grande do Sul traz uma gama de julgados, firmando sua posição a favor da personalidade do nascituro. Cf., também, Recursos Cíveis n. 71000611665, n. 71002001048 e n. 71001157478; e Apelação Cível n. 70002027910. Ambos do Tribunal de Justiça do Rio Grande do Sul.
} 
E, embora não haja unanimidade no Tribunal de Justiça de São Paulo, também já é possível encontrar decisão nesse mesmo sentido, sob o fundamento do reconhecimento do direito à vida do nascituro:

\begin{abstract}
Considerando que existe vida desde a concepção, segundo a teoria da nidação, a interrupção da gravidez com a morte do nascituro acarreta a proteção legal. Não há porque diferenciar para fins de indenização a morte de pessoa já nascida de morte do nascituro, eis que a lei não faz distinção. HONORÁRIOS ADVOCATÍCIOS - DEZ POR CENTO SOBRE O VALOR DO DÉBITO - FIXAÇÃO ADEQUADA EM RAZÃO DA RAZOABILIDADE. O feito desenvolveu-se regularmente até a prolação da sentença sem maiores incidentes e, tendo em vista que a lide envolveu matéria de direito, mostra-se adequada a fixação dos honorários advocatícios no mínimo legal. RECURSOS NÃO PROVIDOS, com observação quanto ao termo inicial dos juros moratórios. (TJSP, Ap. Cív. n. 902351000, relator Des. Alfredo Fanucchi, 30ª Câmara, J. em 05.04.2006). ${ }^{283}$
\end{abstract}

Ainda, podemos citar a Apelação Cível n. 2007.030592-5, da $3^{\text {a }}$ Turma Cível do Mato Grosso do Sul, julgada em 2008 284 , e a Apelação Cível n. 0118477-04.2005.8.19.0001 (2006.001.13466), da $8^{a}$ Câmara Cível do Tribunal de Justiça do Rio de Janeiro, julgada em 2006, ${ }^{285}$ nas quais foram concedidas o seguro obrigatório DPVAT pela morte do nascituro.

Mas não apenas nos casos envolvendo a possibilidade de indenização por seguro obrigatório DPVAT que verificamos o direito à indenização por ofensa ao direito à vida do nascituro. Também encontramos na doutrina e nos tribunais brasileiros questões referentes à indenização pela morte do nascituro causada por erro médico. Nestes casos, os tribunais têm sido consentes em conferir indenização, embora sob diferentes fundamentos. Ora considerando devida

\footnotetext{
${ }^{283}$ Nesse mesmo sentido ver Ap. Cív. n. 2007.030592-5/0000-00 do Tribunal de Justiça do Mato Grosso do Sul. E, em sentido contrário, ver Ap. Cív. n. 818.666-0/6, da 34ª Câmara de Direito Privado do Tribunal de Justiça de São Paulo, Ap. n. 954817-0/0, da 28 Câmara Cível do Tribunal de Justiça de São Paulo, e Apelação n. 1.224.297-0 do $1^{\circ}$ Tribunal de Alçada Cível de São Paulo. Também: Apelação Cível n. 0221930-7, do Tribunal de Justiça do Paraná. ${ }^{284}$ APELAÇÃOO CÍVEL - AÇÃO DE COBRANÇA DE SEGURO OBRIGATÓRIO - PRELIMINAR IMPOSSIBILIDADE JURÍDICA DO PEDIDO - EVENTO MORTE - NASCITURO - DIREITO À PERCEPÇÃO DE INDENIZAÇÃO - NEXO DE CAUSALIDADE ENTRE ACIDENTE E O EVENTO MORTE PRELIMINARES AFASTADAS - MÉRITO - VINCULAÇÃO DO MONTANTE INDENIZATÓRIO AO SALÁRIO MÍNIMO - POSSIBILIDADE QUE NÃO IMPLICA VIOLAÇÃO AOS DISPOSITIVOS DA LEI N. 6.205/75 - INAPLICABILIDADE DAS RESOLUÇÕES EMANADAS PELO CNSP POR ESTAREM EM DESCONFORMIDADE COM A LEI N. 6.194/74 - MONTANTE INDENIZATÓRIO CALCULADO COM BASE NO SALÁRIO MÍNIMO VIGENTE QUANDO DA OCORRÊNCIA DO EVENTO DANOSO - CORREÇÃO MONETÁRIA A PARTIR DA MESMA DATA - HONORÁRIOS ADVOCATÍCIOS - MINORAÇÃO - RECURSO CONHECIDO E PARCIALMENTE PROVIDO.(TJMS, Ap. Cív. n. 2007.030592-5, $3^{\mathrm{a}}$ Turma Cível, Rel. Des. Oswaldo Rodrigues de Melo, DJ 08/01/2008).

${ }^{285}$ COBRANÇA. SEGURO OBRIGATÓRIO. ACIDENTE DE TRÂNSITO. ATROPELAMENTO QUE RESULTOU NA MORTE DE NASCITURO. INDENIZAÇÃO RELATIVA AO SEGURO OBRIGATÓRIO DPVAT. CABIMENTO. DESPROVIMENTO DO RECURSO. (TJRJ, Apelação n. 0118477-04.2005.8.19.0001 (2006.001.13466), Des. ODETE KNAACK DE SOUZA, Julgamento: 04.05.2006, OITAVA CAMARA CIVEL).
} 
a indenização por danos morais à mãe parturiente ${ }_{2}^{286}$ ora considerando devida a indenização por danos próprios do nascituro. ${ }^{287}$

Maria Helena Diniz traz também outros exemplos de danos causados ao nascituro que podem acarretar a sua morte e que implicariam direito à indenização, à parte as hipóteses de acidente de veículos: aborto por motivo socioeconômico, ideológico ou particular da gestante, bem como para resguardar sua honra, saúde física ou mental ou em benefício da saúde de seus filhos, marido, etc. (usando a medula espinhal do feto, por exemplo, no tratamento de leucemia de seus outros filhos); morte por negligência médica, atropelamento ou acidente de trânsito sofrido pela mãe. ${ }^{288}$

Conforme se pode extrair dos julgados e das tendências da jurisprudência, atualmente é concedida a indenização por morte do nascituro tanto por quem reconhece a personalidade jurídica do nascituro, como por quem não a reconhece. No primeiro caso, com fundamento na transmissibilidade do dano moral, no segundo, com fundamento em dano moral causados aos pais, como direito próprio. ${ }^{289}$

Outra questão que surge nessa seara de indenização pela morte do nascituro, diz respeito ao quantum: se este seria igual ao de um filho já nascido, não havendo que se quantificar diferença de valores pela morte de um filho, já que o dano moral consiste numa lesão à personalidade, ou não, posto não considerar o nascituro pessoa, mas apenas reparando a interrupção da gestação.

Nesse sentido, a decisão proferida em razão do Recurso Especial n. 399.028/SP, julgado em 26 de fevereiro de 2002, evidencia a importância prática de saber a natureza jurídica do nascituro para fins de quantificação da indenização:

I - Nos termos da orientação da Turma, o direito à indenização por dano moral não desaparece com o decurso de tempo (desde que não transcorrido o lapso prescricional), mas é fato a ser considerado na fixação do quantum. II - O nascituro também tem direito aos danos morais pela morte do pai, mas a circunstância de não tê-lo conhecido em vida tem influência na fixação do quantum. (STJ, REsp 399.028/SP, Rel. Ministro Sálvio de Figueiredo Teixeira, $4^{\mathrm{a}}$ Turma, julgado em 26.02.2002).

\footnotetext{
${ }^{286}$ Nesse sentido, TJRO, 27.06.1995, RT 729/290; TJRS, j. 13.10.1994, RJTJRS 169/315.

${ }^{287}$ Conforme Apelação Cível n. 70002027910, do Tribunal de Justiça do Rio grande do Sul.

${ }^{288}$ DINIZ, Maria Helena. Curso de Direito Civil Brasileiro, v. 7, p. 200.

289 CHINELLATO, Silmara Juny de Abreu. O nascituro perante os Tribunais. A recente decisão do Tribunal de Justiça de São Paulo, p. 226.
} 
Por outro lado, o Supremo Tribunal de Justiça, em momento posterior, entendeu que a fixação do valor relativo à indenização, pela morte do genitor, deveria se dar desde o evento morte:

\begin{abstract}
1. Impossível admitir-se a redução do valor fixado a título de compensação por danos morais em relação ao nascituro, em comparação com outros filhos do de cujus, já nascidos na ocasião do evento morte, porquanto o fundamento da compensação é a existência de um sofrimento impossível de ser quantificado com precisão. 2. Embora sejam muitos os fatores a considerar para a fixação da satisfação compensatória por danos morais, é principalmente com base na gravidade da lesão que o juiz fixa o valor da reparação (...) (REsp 931556/RS, Rel. Ministra Nancy Andrighi, julgado em 17.06.2008).
\end{abstract}

A forma mais consente com o escopo atual da responsabilidade civil de ampla reparação e com os ditames constitucionais de respeito à dignidade humana é a que concede indenização pela morte do nascituro, reconhecendo sua personalidade. Neste caso, o fundamento na responsabilidade civil ocorre da mesma forma que o da morte do já nascido, pelo dano moral (puro ou com reflexos patrimoniais), e sua indenização é determinada pelos mesmos critérios que norteiam a indenização por morte de filho menor.

No que diz respeito à integridade física ou psicológica do nascituro, os temas a serem discutidos giram em torno, principalmente, dos atos nocivos causados por terceiros ou pelos próprios genitores à saúde e à integridade física do nascituro, tais como o erro médico ou o dano causado pela mãe por falta de cuidado ou conduta prejudicial à saúde do nascituro durante a gestação. $^{290}$

Perante os tribunais, a questão mais tormentosa relativa a ofensa à integridade física da vida intrauterina, causadora de deformações, traumatismos, toxiinfecções, intoxicações, etc., versou sobre casos de medicação inadequada ministrada à gestante, a talidomida. Tal medicação possui efeitos teratogênicos e foi causadora de malformações fetais, gerando inúmeras ações

\footnotetext{
${ }^{290}$ Silmara Juny de Abreu Chinellato ressalta a lenta evolução da jurisprudência brasileira acerca da indenização dos danos pré-natais causados ao nascituro. A evolução na jurisprudência brasileira acerca da indenização por danos prénatais pode ser encontrada no livro Tutela Civil do nascituro; no artigo Bioética e dano pré-natal. In: FERRARI, Paulo Leme (Coord.). Direito de família. Homenagem a Sérgio Marques da Cruz. Revista do Advogado, São Paulo, Associação dos Advogados de São Paulo, n. 58, p. 62-77, mar. 2000; no artigo Tendências da Responsabilidade Civil. In: DELGADO, Mário Luiz; ALVES, Jones Figueirêdo (Coord.). Questões Controvertidas no Novo Código Civil. v. 5. São Paulo: Método, 2006; e no artigo O nascituro perante os Tribunais: A recente decisão do Tribunal de Justiça de São Paulo. Evolução e tendências, Revista do Advogado, São Paulo, n. 20, p. 222-230, jul.-dez. 2007.
} 
judiciais contra as indústrias farmacêuticas, às quais foram impostas indenizações por dano moral e pagamento de pensão especial e vitalícia à vítima. ${ }^{291}$

Outro tema de muitas discussões nos tribunais refere-se à responsabilidade médica por erros no tratamento pré-natal. Nesse sentido os Tribunais de Justiça do Rio Grande do Sul, de Minas Gerais, de São Paulo, do Distrito Federal e do Espírito Santo já decidiram pela necessidade de indenizar por erro médico no acompanhamento de gravidez, causador de lesão à vida intrauterina:

\begin{abstract}
Apelação Cível. Erro médico. Danos Morais e materiais. Age com culpa, por imprudência, negligência e imperícia, médico obstetra que deixa de constatar o sofrimento fetal, mantendo o procedimento de parto normal sem aplicação de técnicas auxiliares a expulsão do nascituro, e, no momento critico do parto, entrega a parturiente aos cuidados exclusivos da enfermeira assistente, saindo da sala cirúrgica, vindo a nascer o bebê com graves lesões neurais decorrentes de anoxia, que o condena a uma vida vegetativa. Danos materiais decorrentes das despesas com permanente tratamento médico, vencidas e vincendas, a serem apuradas em liquidação de sentença. Pensionamento vitalício mensal a criança amparado nas consequiências do dano. Pensionamento aos pais, pelo período correlato a idade entre 14 e 25 anos. Constituição de capital assecuratório, nos termos do art. 602 do CPC, possibilidade de substituição por caução idônea. Quantum indenizatório fixado dentro de parâmetros adequados a circunstâncias da causa Apelação desprovida, com explicitações.” (TJRS, Ap. Cív. n. 70003566577, 6a Câmara Cível, relator o desembargador Carlos Alberto Alvaro de Oliveira, J. em 15/05/2002).
\end{abstract}

Age com culpa o médico que não procede ao devido acompanhamento de paciente que se encontra em trabalho de parto, aplicando-lhe medicamentos que colocam em risco a saúde do nascituro. (TJMG, Ap. Cív. n. 458.416-3, relator o desembargador Sebastião Pereira de Souza, j. 22.06.2005, publicado em 05.08. 2005).

Ação de indenização por danos materiais e morais em razão de seqüelas que ocasionaram danos físicos no nascituro durante o procedimento de parto - imprudência, negligência e imperícia do médico e do hospital demonstradas por falta de atendimento e procedimento adequados para evitar a lesão - responsabilidade por danos materiais e morais por erro médico, com seqüelas irreversíveis - cabimento. Apelo provido para dar pela precedência parcial da ação. (TJSP, Ap. Cív. com revisão n. 147.460-4/6-00, 10ª Câmera de Direito Privado, relator Des. Testa Marchi, J. em 04.10.2005).

CONSTITUIÇÃO FEDERAL. RESPONSABILIDADE DO ESTADO. ATO OMISSIVO. CULPA. DANO MORAL. DANO MATERIAL. FIXAÇÃO DA INDENIZAÇÃO. ERRO MÉDICO. HOSPITAL PÚBLICO. HONORÁRIOS ADVOCATÍCIOS. CONDENAÇÃO DA FAZENDA PÚBLICA. CRITÉRIOS PARA FIXAÇÃO DA VERBA HONORÁRIA. Art. 20, § $4^{\circ}$, CPC. 1. Adotou o direito brasileiro a responsabilidade objetiva do Estado, por atos de seus agentes que nessa

\footnotetext{
${ }^{291}$ Em 1976 foi intentada a primeira ação civil pública na Justiça Federal (ACP n. 5678/76), a qual teve resultado positivo no intento de ser fixada indenização por danos às vítimas da talidomida. Em 1982 foi publicada a Lei federal n. 7070, que determinou que fosse dada pensão de caráter indenizatório para as vítimas da talidomida nascidas entre 01.01.1957 e 31.12.1965. Em 1997 foi intentada nova ação civil pública, movida pelo Ministério Público Federal, para obter indenização por danos morais. As crianças, vítimas da talidomida, nascidas após 1998, devem ajuizar suas próprias ações para pleitear suas indenizações.
} 
qualidade causarem danos injustos a terceiros. Significa dizer que basta a ocorrência do dano injusto e a comprovação do nexo causal para gerar a obrigação de reparar a lesão sofrida pelo particular. 2. Em relação aos atos omissivos, a responsabilidade do Estado é subjetiva. Com isso, deve ser demonstrado o dolo ou culpa dos agentes públicos. 3. É patente o dever de reparação do dano por parte Estado, quando presta serviços médicohospitalares com deficiência, causando lesões permanentes ao usuário. Nessas situações, quando seus agentes atuam com imperícia na condução do parto, deixando de adotar as providências necessárias para impedir que o nascituro experimente sofrimento agudo, com a deformação cerebral determinante das seqüelas como as que com elas se apresenta o autor, os elementos da responsabilidade civil se revelam por inteiro. 4. A fixação da indenização por danos morais, dado que tem natureza meramente compensatória, não é de ser modificada quando se revela revestida de proporcionalidade. 5. Na fixação da verba honorária contra a Fazenda Pública de acordo com o art. $20 \S 4^{\circ}$, não havendo impugnação específica quanto aos elementos que a informam, descabe a majoração pretendida. 6. Recurso do réu conhecido e improvido. Recurso do autor conhecido e parcialmente provido.(TJDFT, Ap. Cív. n. 20020110599819, Relator CARLOS RODRIGUES, $2^{\text {a }}$ Turma Cível, julgado em 13/09/2006, DJ 21/11/2006 p. 428).

EMENTA: HABEAS CORPUS - AÇÃO PROPOSTA PELA GENITORA DO NASCITURO FUNDAMENTANDO-SE NO DIREITO CONFERIDO E ELE DE NASCER DIGNAMENTE - ATENDIMENTO PRÉ E PÓS -NATAL - NASCIMENTO EM LOCAL ADEQUADO COM A DEVIDA ASSISTÊNCIA MÉDICA. ORDEM CONCEDIDA. À luz do artigo $2^{\circ}$ do Código Civil, temos que a personalidade civil do homem começa do nascimento com vida. Entretanto, expressamente dispõe o artigo que desde a concepção, os direitos do nascituro são postos a salvo. Dessa forma, resta claro que, havendo qualquer dano ou ameaça de dano ao seu bem-estar físico ou psíquico, ao nascituro cabe proteção. No presente caso justa se faz a concessão da ordem para garantir o direito do paciente ao nascimento com vida e em condições dignas e saudáveis, com observância no princípio da dignidade da pessoa humana. ORDEM CONCEDIDA para garantir um tratamento pré e pós-natal eficiente e imediato, bem como um parto digno à gestante, em local adequado e salubre. (TJES, Classe: Habeas Corpus, 100070002991, Relator : ADALTO DIAS TRISTÃO, Órgão julgador: SEGUNDA CÂMARA CRIMINAL , Data de Julgamento: 28/03/2007, Data da Publicação no Diário: 09/05/2007)

Nestes casos, porém, há que se verificar que, comprovado o erro médico, a possibilidade de indenização não gera maiores controvérsias, uma vez que, havendo lesão à integridade física do feto e independentemente de o nascituro ter ou não reconhecida sua personalidade, concede-se reparação civil, bastando provar o nexo causal entre a conduta e o evento danoso.

Quanto à possibilidade de danos morais causados ao nascituro em sua integridade psicológica durante a gravidez e a consequente possibilidade de reparação civil, temos a Apelação Cível n. 194.026.779, julgada em 17 de novembro de 1994 pelo Tribunal de Justiça do Rio Grande do Sul, em que se decidiu, por unanimidade, pela indenização por dano moral ao nascituro:

Acidente de trânsito. Indenização por dano moral. Induvidosos os sofrimentos, angústia e tensão, por longos oito meses, diante de gravidez com possível prejuízo da vida e/ ou integridade física do nascituro, há dano moral indenizável. (Ap. Cív. 194.026.779, j. em 17.11.1994, Rel. Juiz Geraldo César Fregapani, TJRS). 
Também o Tribunal de Justiça de Goiás, recentemente, na Apelação Cível de n. 12.3944/195, julgada em 25 de setembro de 2007, cujo relator foi o Desembargador Rogério Arédio Ferreira, decidiu indenizar o nascituro pelo abalo emocional sofrido pela mãe durante a gestação de forma a ocasionar danos a sua integridade psicológica. De forma enfática na defesa da teoria concepcionista e do reconhecimento da personalidade do nascituro, o voto do relator trouxe que:

\begin{abstract}
é cediço que, desde a concepção, o nascituro evidencia os seus direitos à vida, à conservação, à liberdade, à defesa, devendo ser a ele assegurado o direito de vir ao mundo de forma sadia, sem traumas, sem deformações, quer físicas, psíquicas ou provocadas, na maioria das vezes, pelas violências que a mãe sofre durante o período de gestação, eis que ele absorve para si, todas as angústias, abalos, dores, crises nervosas e outras anormalidades vivenciadas pela mãe. E o direito, amparado na lei deve dar a proteção real ao ser humano que está por vir. (...) urge como imprescindível que se reconheça ao nascituro a capacidade de sofrer dano moral, merecendo ser ressarcido, pois a indenização do dano não está condicionada a que a pessoa possa compreender o mal que lhe está sendo feito. ${ }^{292}$ (TJGO, Ap. Cív. n. 12.394-4/195, relator desembargador Rogério Arédio Ferreira, j. em 25.09.2007). ${ }^{293}$
\end{abstract}

Conforme já foi dito, os atos nocivos à integridade física ou psicológica do nascituro também podem ser causados pelos próprios genitores durante a gravidez. De acordo com Maria Helena Diniz, a jurisprudência brasileira tem sustentado o direito de a criança movimentar a máquina judiciária para obter indenização por dano pré-natal contra o lesante, seja ele sua mãe (com fundamento no artigo 186 do Código Civil) ou o médico (com fundamento no artigo 14, § $4^{\text {o }}$, da Lei federal n. 8078/90 e no artigo 951 do Código Civil). ${ }^{294}$

Nesse sentido, o Tribunal de Justiça de Minas Gerais, aplicando os artigos $2^{\circ}$ do Código Civil e $7^{\circ}, 8^{\circ}$ e $9^{\circ}$ do Estatuto da Criança e do Adolescente, buscou garantir o direito ao desenvolvimento e nascimento sadio do nascituro, cuja gestante era uma adolescente usuária de drogas. Na decisão de primeiro grau, o juiz invocou o princípio da Doutrina da Proteção Integral da Organização das Nações Unidas (ONU) para aplicar à adolescente medida de internação em

\footnotetext{
${ }^{292}$ O inteiro teor deste acórdão está disponível em: <www.tjgo.jus.br>. Acesso em: 10 nov. 2009.

293 Podemos citar, ainda, decisão em âmbito administrativo, de 2007, proferida pela Comissão Estadual de Ex-presos Políticos de São Paulo, na qual foi concedida indenização ao nascituro por ter sido ele reconhecido como "preso político e vítima de tortura” pela ditadura militar. Disponível em: <www.conjur.com.br/2007-fev08/filho_mãe_torturada_gravidez_indenização>. Acesso em: 01 dez. 2009. No mesmo sentido, a Comissão de Reparação do Estado do Rio de Janeiro concedeu indenização pela tortura psicológica sofrida por nascituro. Disponível em: <http://direitodonascituro.blogspot.com/2007/09/italo-nogueira-da-folha-de-s.html>. Acesso em: 01 dez. 2009.

${ }^{294}$ DINIZ, Maria Helena. Curso de Direito Civil Brasileiro. v. 7. São Paulo: Saraiva, 2008. p. 200.
} 
estabelecimento próprio à sua idade e condição, na qual foi concedida à gestante tratamento médico, pré e pós-natal. ${ }^{295}$

Não somente a integridade física e psicológica do nascituro tem sido objeto de discussão nos tribunais, mas também a possibilidade de indenização por outros danos morais, tal como no caso do dano moral sofrido pelo nascituro em razão da morte de seu genitor.

Nesse sentido, o Superior Tribunal de Justiça, em 2008, decidiu por reconhecer ao nascituro o direito à indenização por dano moral pela morte do genitor de forma equivalente à indenização conferida aos irmãos já nascidos quando do acidente de trabalho que ocasionou a morte de seus pais:

RESPONSABILIDADE CIVIL. ACIDENTE DO TRABALHO. MORTE. INDENIZAÇÃO POR DANO MORAL. FILHO NASCITURO. FIXAÇÃO DO QUANTUM INDENIZATÓRIO. DIES A QUO. CORREÇÃO MONETÁRIA. DATA DA FIXAÇÃO PELO JUIZ. JUROS DE MORA. DATA DO EVENTO DANOSO. PROCESSO CIVIL. JUNTADA DE DOCUMENTO NA FASE RECURSAL. POSSIBILIDADE, DESDE QUE NÃO CONFIGURDA A MÁ-FÉ DA PARTE E OPORTUNIZADO O CONTRADITÓRIO. ANULAÇÃO DO PROCESSO. INEXISTÊNCIA DE DANO. DESNECESSIDADE.

- Impossível admitir-se a redução do valor fixado a título de compensação por danos morais em relação ao nascituro, em comparação com outros filhos do de cujus, já nascidos na ocasião do evento morte, porquanto o fundamento da compensação é a existência de um sofrimento impossível de ser quantificado com precisão.

- Embora sejam muitos os fatores a considerar para a fixação da satisfação compensatória por danos morais, é principalmente com base na gravidade da lesão que o juiz fixa o valor da reparação.

- É devida correção monetária sobre o valor da indenização por dano moral fixado a partir da data do arbitramento. Precedentes.

- Os juros moratórios, em se tratando de acidente de trabalho, estão sujeitos ao regime da responsabilidade extracontratual, aplicando-se, portanto, a Súmula n. 54 da Corte, contabilizando-os a partir da data do evento danoso. Precedentes.

- É possível a apresentação de provas documentais na apelação, desde que não fique configurada a má-fé da parte e seja observado o contraditório. Precedentes.

- A sistemática do processo civil é regida pelo princípio da instrumentalidade das formas, devendo ser reputados válidos os atos que cumpram a sua finalidade essencial, sem que acarretem prejuízos aos litigantes.

Recurso especial dos autores parcialmente conhecido e, nesta parte, provido. Recurso especial da ré não conhecido. (REsp 931556 / RS, 3a Turma, relatora Ministra NANCY ANDRIGHI, J. em 17.06.2008). ${ }^{296}$

Ao que parece, a jurisprudência caminha para o reconhecimento da possibilidade de indenização por danos morais ao nascituro. No entanto, como dito anteriormente, os fundamentos

\footnotetext{
295 Disponível em: <www.direito2.com.br/tjmg/2007/ago/28/justica-garante-direitos-de-nascituro>. Acesso em: 10 nov. 2009.

${ }^{296}$ Em sentido contrário, em 2002, no Recurso Especial n. 399028/SP, o STJ havia decidido por reconhecer danos morais ao nascituro pela morte do pai, mas a circunstância de não tê-lo conhecido em vida havia influído na fixação do quantum. A decisão exarado no REsp 931556/RS reflete o novo entendimento do STJ e a nova tendência desse Tribunal.
} 
da indenização ainda são frágeis e os julgados apontam, por isso, divergências quanto ao momento inicial em que se deve fixar a indenização, se a partir da concepção ou a partir do nascimento com vida.

Na Apelação Cível n. 489.775-0/7, julgada perante a 10a Câmara do $2^{\circ}$ Tribunal de Alçada Cível de São Paulo, na qual se pleiteava indenização pela morte do pai, falecido em acidente de trabalho por negligência da empregadora, o filho, nascido após o evento morte, só teve reconhecido seus direitos na esfera material e moral a partir da data do nascimento:

AÇÃO ACIDENTÁRIA PELO DIREITO COMUM RESPONSABILIDADE DA
EMPREGADORA COMPROVADA - DANO MORAL DEVIDO - INDENIZAÇÃO A
CONTAR DO NASCIMENTO DO AUTOR - Comprovada a responsabilidade da
empregadora pelo acidente letal de seu empregado, é devida a indenização ao filho dele,
até que complete 21 anos de idade. Devida é, também, a indenização, por dano moral,
desde o nascimento, ao nascituro, que nasceu com vida, como reparo pela perda do
genitor”. ( $2^{\circ}$ TAC de SP, $10^{a}$ Câm., Ap. n. 489.775-0/7, Rel. Juiz Adail Moreira, j.
29.10.1997).

Mas no Recurso Especial n. 931556, como visto, o filho teve seu direito reconhecido desde a concepção e no mesmo quantum de seus irmãos, já nascidos à época do acidente de trabalho que culminou na morte de seu pai.

O Tribunal de Justiça de Goiás, da mesma forma que o Superior Tribunal de Justiça, no julgamento do Recurso n. 12394-4/195, em 25 de setembro de 2007, concedeu indenização desde o evento morte:

DUPLO GRAU DE JURISDICAO. DUPLO APELO. ACAO DE INDENIZACAO POR DANOS MORAIS. ABORDAGEM INDEVIDA DE POLICIAIS MILITARES. CARACTERIZACAO DE DANO. JULGAMENTO EXTRA PETITA. CULPA EXCLUSIVA DAS VITIMAS. INOCORRENCIA. NASCITURO. DANO MORAL. CORRECAO MONETARIA. HONORARIOS ADVOCATICIOS. FIXACAO DO QUANTUM. RAZOABILIDADE. 1 - DEVE SER EXCLUIDA A INDENIZACAO ARBITRADA EM FAVOR DA MAE MENOR QUE NAO ENCONTRAVA-SE NO MOMENTO DA ABORDAGEM POLICIAL, FIGURANDO NOS AUTOS APENAS NA CONDICAO DE REPRESENTANTE LEGAL DE SUA FILHA. 2 - RESTANDO

\footnotetext{
${ }^{297}$ O mesmo se verifica na Apelação Cível n. 6521055800: “APELAÇÃO CÍVEL _ RESPONSABILIDADE CIVIL E INDENIZAÇÃO - Morte de genitor por policial militar, que em gozo de suas férias utilizou-se da prerrogativa que o cargo lhe confere - Disparo efetuado com arma da corporação - Responsabilidade objetiva do Estado por atos praticados por seus agentes - Dano moral do nascituro - Cabimento - Valor razoavelmente fixado - Observância do critério repressivo e da vedação do enriquecimento sem causa - Pensão alimentícia - Cabimento - Dever do genitor de pagar alimentos, independentemente de ser menor de idade à época dos fatos - Valor correspondente a um terço do salário mínimo, desde o nascimento da autora até que ela venha a completar vinte e quatro anos de idade Entendimento firmado no E. Superior Tribunal de Justiça - Provimento em parte da pretensão inicial - Autora que decaiu de parte mínima do pedido - Condenação da ré ao pagamento das verbas sucumbenciais - Reforma da r. sentença a quo de improcedência - Provimento em parte. (Ap. n. 6521055800, j. em 24/09/2008, Rel. Des. Prado Pereira).
} 


\begin{abstract}
COMPROVADA A ATUACAO DOS AGENTES PUBLICOS - POLICIAIS MILITARES, O DANO MORAL EXPERIMENTADO PELOS AUTORES E O NEXO DE CAUSALIDADE, CARACTERIZADA ESTA A OBRIGACAO DO ESTADO EM RESSARCI-LOS, NAO HAVENDO QUE SE FALAR EM CULPA EXCLUSIVA DAS VITIMAS E NEM EM ESTRITO CUMPRIMENTO DO DEVER LEGAL. 3 CONFORME ENTENDIMENTO DA TEORIA CONCEPCIONISTA E BASEADO NO PACTO DE SAO JOSE DA COSTA RICA, O NASCITURO E CONSIDERADO PESSOA DESDE A CONCEPCAO, DEVENDO SER RESGUARDADA SUA VIDA, INTEGRIDADE FISICA E SAUDE, PODENDO SER INDENIZADO SE OCORRER ALGUM ATO ILICITO QUE LHE PREJUDIQUE OU COLOQUE EM RISCO SUA VIDA, NO PERIODO DA GESTACAO DE SUA MAE. 4 - NA INDENIZACAO POR DANO MORAL, ADVINDA DE RESPONSABILIDADE EXTRACONTRATUAL, A CORRECAO MONETARIA DEVE INCIDIR A PARTIR DO ATO JUDICIAL QUE FIXOU O MONTANTE DA CONDENACAO. 5 - OS HONORARIOS ADVOCATICIOS FORAM FIXADOS CONSOANTE APRECIACAO EQUITATIVA DO JUIZ, ATENDIDAS AS DISPOSICOES DO ART. 20 DO CODIGO DE PROCESSO CIVIL. 6 - DEVE-SE MANTER O QUANTUM A SER INDENIZADO QUANDO O JUIZ MONOCRATICO FIXA DO VALOR COM MODERACAO E RAZOABILIDADE. PRIMEIRA APELACAO CONHECIDA E IMPROVIDA. REMESSA E SEGUNDA APELACAO CONHECIDAS E PARCIALMENTE PROVIDAS. (TJGO, processo n. 200600898827, Recurso 12394-4/195, $3^{\text {a }}$ Câm. Cível, j. em 25.09.2007).
\end{abstract}

Acerca da controvérsia, Silmara Juny de Abreu Chinellato aponta que os direitos do nascituro se verificam desde a concepção. Nesse sentido, também Euclides Benedito de Oliveira assim aduz:

\begin{abstract}
legitima-se o nascituro a reclamar danos patrimoniais e morais, desde a concepção, quando beneficiário direto de violações a direitos de outrem, como na hipótese de genitor falecido por ação alheia derivada de dolo ou culpa.

Se ao filho se reconhecem tais direitos, não importa que idade ou compreensão tenha, bastando que se afiram os prejuízos decorrentes da perda sofrida, o mesmo haverá de ser garantido ao nascituro. Somente assim estará ele sendo atendido na plenitude dos seus direitos desde o momento da concepção, conforme lhe assegura o ordenamento legal. ${ }^{298}$
\end{abstract}

O autor ainda acrescenta, na defesa do reconhecimento da indenização civil ao nascituro, que a reparação pelo Direito Civil, em caso de acidente de trabalho, é assegurada pelo artigo $7^{\circ}$, inciso XXVIII, da Constituição Federal, independentemente da reparação obtida pelo seguro acidentário (INSS). ${ }^{299}$

Com relação aos danos morais possíveis de serem causados à personalidade do nascituro, cabe mencionar, ainda, que o nascituro também pode sofrer lesão ao seu direito à honra (imagem atributo), como no caso de imputação à bastardia, ou ao seu direito à imagem (imagem retrato), como no caso de captação de retrato (ultrassonográfico) não autorizado. ${ }^{300}$

\footnotetext{
${ }^{298}$ OLIVEIRA, Euclides Benedito. Indenização por danos morais ao nascituro, p. 145.

${ }^{299}$ Ibidem, p. 146.

${ }^{300}$ DINIZ, Maria Helena Diniz. Curso de Direito Civil Brasileiro, v. 7, p. 200.
} 
Percebe-se, portanto, que por uma via lenta, e por vezes distorcida, os tribunais têm reconhecido a reparação civil ao nascituro por ofensa à sua personalidade. Mas resta ainda avançar ao reconhecimento da reparação civil consubstanciado na ofensa à personalidade do nascituro considerado como pessoa, não se utilizando de subterfúgios ou justificativas outras que não a de dano moral ao nascituro fundamentado em sua natureza jurídica de pessoa. Só dessa forma teremos a efetivação do escopo da responsabilidade civil da ampla reparação. Exemplo disso estaria na possibilidade de transmissibilidade do dano moral causado nascituro. Afinal, conforme dispõe Carlos Roberto Gonçalves:

malgrado os direitos da personalidade, em si, sejam personalíssimos (direito à honra, à
imagem, etc.) e, portanto, intransmissíveis, a pretensão ou direito de exigir a sua
reparação pecuniária, em caso de ofensa, transmite-se aos sucessores, nos termos do art.
943 do Código Civil. ${ }^{301}$

Por fim, no que diz respeito aos danos morais causados ao nascituro, merece destaque tema que tem sido alvo de discussão nos tribunais de países europeus e que diz respeito às ações de wrongful life e wrongful birth. ${ }^{302}$ Nesse tópico de danos pré-natais será tratado apenas o primeiro tipo de ação, que, inclusive, tem sido alvo de maiores debates, deixando o segundo tipo de ação para o tópico de dano aos pais.

Embora ainda não tenhamos nenhum caso julgado pelos tribunais superiores brasileiros do que se costuma chamar na doutrina nascente de wrongful life, aventam-se na doutrina e jurisprudência estrangeira, sem opinião uniforme ainda, casos que chamam a atenção da comunidade jurídica e que merecem menção. Wrongful life consiste nas situações em que os pais, representando seus filhos, entram com ações por danos a estes, por terem nascido com graves anomalias, não detectadas pelo médico ou não informada por este aos pais, impedindo, com isso, a interrupção da gravidez. ${ }^{303}$

Fernando Pinto Monteiro, ao tratar do tema em artigo publicado no segundo volume da Comemoração dos 35 anos do Código Civil e dos 25 anos da reforma de 1977 do Código Civil Português, divide essas ações em duas classes: (i) ação intentada pelo filho contra os pais, por não terem observado aconselhamentos médicos, entre outras hipóteses; e (ii) ação intentada pela pessoa nascida contra os médicos por estes não terem fornecido aos pais as informações

\footnotetext{
${ }^{301}$ GONÇALVES, Carlos Roberto. Direito Civil Brasileiro: Responsabilidade Civil, p. 368.

302 Traduzidos literalmente como "vida errada" e "nascimento errado".

${ }^{303}$ MONTEIRO, Antonio Pinto. Direito a não nascer? Revista do IASP, ano 10, n. 19, jan.-jun./2007, p. 324.
} 
necessárias sobre a gravidez e que os teriam levado a interrompê-la, evitado, assim, o nascimento. $^{304}$

De um modo geral, a jurisprudência dos países que já enfrentaram tais questões (como a norte-americana, a inglesa, a alemã e a espanhola) não reconhecem a indenização pedida pela criança, devidamente representada, por ter nascido com malformações. ${ }^{305}$ Essa não foi, entretanto, a posição adotada pelo tribunal francês num primeiro momento, em caso paradigmático, conforme vamos ver adiante na análise de alguns importantes casos já julgados por outros países. ${ }^{306}$

O primeiro caso de que se tem conhecimento foi julgado pela jurisprudência norteamericana e remonta a 1967.Trata-se do caso Goldberg v. Ruskins, julgado pela Suprema Corte de Ilinois, no qual a criança, por meio de seus pais, propôs ação judicial contra o médico por este não ter alertado sobre os riscos da gestação, impossibilitando-os de realizar a interrupção da gravidez. $^{307}$

Mas, o primeiro julgamento sobre wrongful life em que se concedeu o direito à indenização pelos danos causados pelo simples fato de ter ocorrido nascimento, foi realizado pelo tribunal francês, no caso Nicolas Perruche. Em virtude da falta de informação do médico a respeito da doença, a mãe ficou impossibilitada de abortar, gerando um filho deficiente. A Corte Francesa, à época do julgamento, datado de 17 de novembro de 2000, entendeu que houve responsabilidade do médico, não somente perante a mãe, mas também perante a criança, por violação do seu direito de não nascer. ${ }^{308}$

Tendo em vista a grande repercussão social causada pelo julgamento do caso, foi realizada uma intervenção legislativa, com a edição da lei francesa n. 2002-303, de 04 de março de 2002, vedando indenizações por danos ao filho pelo simples fato de ter ocorrido nascimento.

\footnotetext{
${ }^{304}$ Cf. MONTEIRO, Fernando Pinto. Direito à não existência, direito a não nascer. In: Comemoração dos 35 anos do Código Civil e dos 25 anos da reforma de 1977. v. 2 - A Parte Geral do Código e a Teoria Geral do Direito Civil. Coimbra: Coimbra Editora, 2006. p. 131-132.

${ }^{305}$ MORILLO, Andrea Mácia. La responsabilidad médica por los diagnósticos preconceptivos y prenatales (las llamadas acciones de wrongful birth y wrongful life), p.120-144.

${ }^{306}$ MONTEIRO, Antônio Pinto. Direito a não nascer?, p. 324.

${ }^{307}$ MONTEIRO, Fernando Pinto. Direito à não existência, direito a não nascer. In: Comemoração dos 35 anos do Código Civil e dos 25 anos da reforma de 1977, v. 2, p. 132.

${ }^{308}$ MONTEIRO, Antônio Pinto. Op. cit., p. 325. Mais detalhes sobre o caso pode ser consultado também no site da Cour de Cassation francesa, disponível em: <www.courdecassation.fr>. Acesso em: 11 out. 2009.
} 
Tais ações também chegaram aos tribunais portugueses. ${ }^{309}$ A primeira ação de wrongful life a chegar no Supremo Tribunal de Justiça data de junho de 2001: ação com pedido de indenização por danos patrimoniais e não patrimoniais, movida por menor de 3 anos de idade, representado pelos pais, contra médico e clínica privada por não terem informado à mãe anomalias na gravidez, nem terem conferido o cuidado devido ao caso, inviabilizando a opção pela interrupção da gravidez. A discussão não era sobre a culpa do médico ou não nas malformações com que nascera o autor, ou na possibilidade de ele ter nascido sem tais deficiências, mas sim sobre a não informação acerca das malformações que eram detectáveis desde cedo, impossibilitando os pais do autor de recorrerem à interrupção da gravidez voluntária. Ou seja, a ação buscava indenização pelo “dano de ter nascido”causado à criança, e por isso foi intentada pelo menor e não por seus pais. Foi decidido pelo Supremo Tribunal de Justiça de Portugal que não havia lugar a qualquer indenização, por não existir tal direito no ordenamento jurídico português. O autor menciona que os pais da criança propuseram outra ação, com base no wrongful birth, ${ }^{310}$ ainda não levada ao Supremo Tribunal de Justiça. ${ }^{311}$

No Brasil, dificilmente chegarão aos nossos tribunais causas envolvendo wrongful life, já que nossa legislação não permite o aborto.

\subsubsection{Dano Patrimonial Causado ao Nascituro}

Os danos patrimoniais propriamente ditos, passíveis de serem causados ao nascituro, já têm sua proteção garantida, genericamente, pelo Código Civil desde a concepção, sob condição resolutiva do nascimento com vida. E, mesmo para os defensores da teoria concepcionista, uma

\footnotetext{
${ }^{309}$ Disponíveis em: <www.stj.pt>. Acesso em: 11 out. 2009.

310 Conforme se vai ver em tópico próprio, “wrongful birth” é expressão que se refere aos casos em que os pais pedem indenização por danos próprios, resultantes do nascimento de um filho não desejado, ocorrido por esterilizações ou interrupções de gravidez mal sucedidas, ou por falta de informações médicas sobre anomalias da criança.

${ }^{311}$ MONTEIRO, Fernando Pinto. Direito à não existência, direito a não nascer. In: Comemoração dos 35 anos do Código Civil e dos 25 anos da reforma de 1977, v. 2, p. 134-138. O autor levanta ainda a hipótese de que mesmo que fosse reconhecido tal direito de não nascer, ele só poderia ser questionado pela própria pessoa, após adquirida a maioridade, e não por seus representantes.
} 
vez que os direitos patrimoniais do nascituro encontram-se sob a condição do nascimento, apenas após este momento poderia se pensar em danos patrimoniais, não gerando maiores debates.

Entre os danos patrimoniais causados ao nascituro, os mais polêmicos são os que decorrem do dano moral. Trata-se de reflexo dos danos morais em sentido amplo, como por exemplo, o dano que implica direito à pensão em decorrência da morte do genitor do nascituro em acidente de trabalho ocasionado por negligência do empregador; ou o dano que enseja direito à pensão vitalícia concedida ao nascituro por deformidades ocasionadas durante a gestação em razão de conduta médica culposa, entre outros.

Nesse sentido, nossos tribunais já têm decisões a favor do nascituro:

Apelação Cível. Erro médico. Danos Morais e materiais. Age com culpa, por imprudência, negligência e imperícia, médico obstetra que deixa de constatar o sofrimento fetal, mantendo o procedimento de parto normal sem aplicação de técnicas auxiliares a expulsão do nascituro, e, no momento critico do parto, entrega a parturiente aos cuidados exclusivos da enfermeira assistente, saindo da sala cirúrgica, vindo a nascer o bebê com graves lesões neurais decorrentes de anoxia, que o condena a uma vida vegetativa. Danos materiais decorrentes das despesas com permanente tratamento médico, vencidas e vincendas, a serem apuradas em liquidação de sentença. Pensionamento vitalício mensal a criança amparado nas conseqüências do dano. Pensionamento aos pais, pelo período correlato a idade entre 14 e 25 anos. Constituição de capital assecuratório, nos termos do art. 602 do CPC, possibilidade de substituição por caução idônea. Quantum indenizatório fixado dentro de parâmetros adequados a circunstâncias da causa Apelação desprovida, com explicitações.” (Ap. Cív. n. 70003566577, 6ª Câmara Cível, Tribunal de Justiça do RS, Relator: Carlos Alberto Alvaro de Oliveira, Julgado em 15/05/2002).

DIREITO CIVIL - PROCESSO CIVIL - PRESCRIÇÃO - PROVA PERICIAL - LIVRE CONVENCIMENTO MOTIVADO - REPARAÇÃO CIVIL - ERRO MÉDICO RESPONSABILIDADE SUBJETIVA - INDENIZAÇÃO DEVIDA - VALOR DA INDENIZAÇÃO - Quando o pedido é indenizatório, em que se requer a reparação pelos danos decorrentes de erro médico, a ação é in personam, que ocorre quando se age contra quem se obrigou por contrato ou por ilícito, isto é, quando pretendemos uma obrigação de dar, fazer ou prestar alguma coisa. Assim, deve-se aplicar a regra do art. 177 do CC/1916. - É ônus das partes o requerimento das provas que entendem pertinentes a demonstrar o seu direito. - Decidindo de forma fundamentada, a apreciação das provas presentes nos autos ocorre livremente pelo magistrado. - Age com culpa o médico que não procede ao devido acompanhamento de paciente que se encontra em trabalho de parto, aplicando-lhe medicamentos que colocam em risco a saúde do nascituro. - Recurso a que se nega provimento. (TJMG, Ap. Cív. n. 2.0000.00.4584163/000(1), Rel. Sebastião Pereira de Souza, J. em 22.06.2005).

Ainda, podemos fazer referência à decisão do Tribunal de Justiça de São Paulo, no qual foi concedida, pela morte do nascituro, além de indenização à mãe por dano moral próprio, 
indenização por danos patrimoniais ocasionados pela morte do nascituro, sendo devida pensão da data em que a filha da autora completaria 14 anos até seu $69^{\circ}$ aniversário. ${ }^{312}$

No mais, há que se remeter às mesmas questões já travadas no item anterior.

\subsubsection{Dano Causado aos Pais: Morte do Nascituro e Wrongful Birth}

Para aqueles que não reconhecem a personalidade do nascituro, sob o ponto de vista dos ascendentes do nascituro, a ofensa à vida deste por ato ilícito de outrem também tem reflexos no sistema da responsabilidade civil A morte do nascituro é fonte de grande dor e sofrimento aos pais e, mesmo que não seja reconhecida indenização por ofensa à personalidade do nascituro, tem sido reconhecida indenização por dano moral aos pais. ${ }^{313}$

\footnotetext{
312 Apelação com Revisão n. 4246565300: RESPONSABILIDADE CIVIL DO ESTADO - ERRO MÉDICO AUSÊNCIA DE ATENDIMENTO MÉDICO-HOSPITALAR ADEQUADO - COMPROVAÇÃO CONJUNTO PROBATÓRIO QUE APONTA PARA A DESÍDIA E IMPERÍCIA DOS PREPOSTOS DA RÉ - EMBORA A CULPA RESTE EVIDENTE, BASTA O NEXO DE CAUSALIDADE ENTRE A CONDUTA DO AGENTE E O EVENTO DANOSO PARA CARACTERIZAR A RESPONSABILIDADE ESTATAL - INTELIGÊNCIA DO ART. 37, § 6o, CF - RECURSO DO IAMSPE DESPROVIDO DANO MORAL - MORTE DE NASCITURO PORQUE OS MÉDICOS QUE ATENDERAM A PARTURIENTE NÃO ADOTARAM AS PROVIDÊNCIAS EXIGÍVEIS PARA A ESPÉCIE - FIXAÇÃO DO QUANTUM INDENIZATÓRIO - VALOR CORRESPONDENTE A 500 SALÁRIOS MÍNIMOS PARA A PARTURIENTE - MONTANTE RAZOÁVEL COMPENSAÇÃO DA VÍTIMA PELA INDESCRITÍVEL DOR SOFRIDA - A INDENIZAÇÃO, CONTUDO, NÃO PODE CONSTITUIR FONTE DE ENRIQUECIMENTO A BANALIZAR O INSTITUTO - RECURSOS DO IAMSPE E DA AUTORA DESPROVIDOS DANOS MATERIAIS - PENSÃO DE UM SALÁRIO MÍNIMO MENSAL, MAIS DÉCIMO TERCEIRO SALÁRIO, DA DATA EM QUE A FILHA DA AUTORA COMPLETARIA 14 ANOS ATÉ SEU 69 ANIVERSÁRIO - CABIMENTO - SOLUÇÃO ADOTADA PELA JURISPRUDÊNCIA -PRESUNÇÃO DE QUE OS FILHOS PRESTAM AUXÍLIO FINANCEIRO AOS PAIS NAS FAMÍLIAS HUMILDES -IMPOSSIBILIDADE, PORÉM, DO PAGAMENTO DA PENSÃO EM PARCELA ÚNICA, OU QUE A MESMA SEJA REVERTIDA EM FAVOR DE TERCEIROS, CASO A BENEFICIÁRIA FALEÇA -RECURSO DA AUTORA DESPROVIDO DANOS MATERIAIS - CUSTEIO DE TRATAMENTO PSICOLÓGICO DESPESAS NÃO COMPROVADAS - FIXAÇÃO DA INDENIZAÇÃO POR DANOS MORAIS QUE CONSIDEROU O ABALO PSICOLÓGICO SOFRIDO - RECURSO DA AUTORA DESPROVIDO DANOS MATERIAIS - DESPESAS COM FUNERAL - PEDIDO NÃO FORMULADO NA INICIAL - SENTENÇA CORRETA, DIANTE DO PRINCÍPIO DA ADSTRIÇÃO AO PEDIDO - RECURSO DA AUTORA DESPROVIDO HONORÁRIOS ADVOCATÍCIOS MAJORAÇÃO - INADMISSIBILIDADE -VERBA BEM FIXADA PELA SENTENÇA, DIANTE DA SUCUMBÊNCIA RECÍPROCA - RECURSO DA AUTORA DESPROVIDO INDENIZAÇÃO - TERMO INICIAL DOS JUROS MORATORIOS E CORREÇÃO MONETÁRIA - DATA DA OCORRÊNCIA DO EVENTO DANOSO - SÚMULAS 43 E 54 DO E. STJ - RECURSO DA AUTORA PROVIDO NESSE TÓPICO APELO DO IAMSPE DESPROVIDO, PARCIALMENTE PROVIDO O APELO DA AUTORA. (Apelação com Revisão n. 4246565300, j. em 28/07/2009, Rel. Des. Renato Nalini).

${ }^{313}$ Podemos citar, como exemplo, os seguintes julgados: REsp 703.194/SC; REsp 472.276/SP, Apelação com revisão n. 424.656-5/3-00, TJSP; Apelação Cível n. 3.309/98, TJRJ; Apelação Cível n. 20000110672319, TJDFT; Apelação n. 95.005038-5, TJRO.
} 
O problema que aqui se instaura, conforme já referido em item anterior, vai além da simples discussão teórica; pois, a depender do entendimento acerca da personalidade do nascituro, temos decisões discrepantes no que se refere ao quantum indenizatório, bem como do dies a quo da indenização. Para maior aprofundamento, remetemos ao item 7.4.1.

Assunto diretamente relacionado a dano aos pais do nascituro refere-se ao tema recente surgido na jurisprudência internacional e que envolve responsabilidade civil, indenização aos pais e ao nascituro. É a chamada "ação de wrongful birth", que figura ao lado das "ações de wrongful life”, as quais, entretanto, possuem fundamentos diferentes.

Conforme expõe Antônio Pinto Monteiro, wrongful birth englobaria as situações em que os pais pedem indenização por danos próprios, sejam patrimoniais ou morais, resultantes do nascimento de um filho não desejado, ocorrido por esterilizações ou interrupções de gravidez mal sucedidas, ou por falta de informações médicas sobre anomalias da criança, interferindo, num ou noutro caso, no poder de planejamento familiar dos pais. ${ }^{314}$

De um modo geral, as jurisprudências dos países que já se afrontaram com tais questões (como Estados Unidos, Inglaterra, Alemanha, Espanha e França), tendem a reconhecer o direito à indenização dos pais em razão de danos por eles sofridos. ${ }^{315}$

No Brasil, tais questões ainda não chegaram aos tribunais e, numa primeira análise, parece que dificilmente seriam concebíveis com base na regra geral de responsabilidade civil, pois o direito não poderia reconhecer como dano o fato do nascimento tout court.

\footnotetext{
${ }^{314}$ MONTEIRO, Antônio Pinto. Direito a não nascer?, p. 324.

${ }^{315}$ MORILLO, Andrea Mácia. La responsabilidad médica por los diagnósticos preconceptivos y prenatales (las llamadas acciones de wrongful birth y wrongful life), p. 120-144.
} 


\section{CONCLUSÃO}

Numa época humanista em que se acredita terem se aperfeiçoado os ideais da igualdade plena, substancial e não meramente formal, num momento em que a luta pela dignidade, pelos direitos e pelo respeito mútuo estão em evidência como nunca antes, em que se fala de efetividade dos direitos fundamentais não somente nas relações dos indivíduos com o Estado, mas também nas relações particulares, encontramos ainda um entrave ideológico no que diz respeito ao nascituro, que, embora possuidor de inegável natureza humana, não tem reconhecida de maneira plena sua personalidade, o que afronta os princípios constitucionais da dignidade humana e da igualdade.

A ciência trouxe a possibilidade de pôr fim às dúvidas existentes quanto ao início do desenvolvimento da vida humana. No entanto, o Direito posto ainda fecha os olhos para a realidade, utilizando-se de conceitos ultrapassados que não acompanham as mudanças socioculturais. Resta à doutrina e aos nossos tribunais a tarefa de compatibilizar o mundo fático com a lei escrita, interpretando as normas jurídicas de acordo com o pensamento jurídico atual sobre a responsabilidade civil e o respeito e valorização da pessoa humana.

Neste trabalho, buscou-se trazer as posições existentes acerca da personalidade jurídica do nascituro, bem como a evolução do pensamento humanista de valorização do ser humano.

Com amparo na legislação pátria, demonstrou-se, também, que o pensamento doutrinário sobre a responsabilidade civil anda ao lado do princípio maior de nossa Constituição, qual seja, o da dignidade humana, uma vez que hoje se valoriza o sujeito vítima e se busca a reparação de todo e qualquer dano sofrido pelo indivíduo ou pela sociedade.

Foi trazida, ainda, uma análise dos julgados dos tribunais brasileiros no que tange à possibilidade de reparação civil por danos causado ao nascituro. E o que se percebeu foi que, embora o entendimento dos tribunais caminhe para efetiva reparação de danos causados ao nascituro, o Poder Judiciário ainda o faz consubstanciado em fundamentos frágeis e equivocados. São concedidas, muitas vezes, indenizações com valores menores dos que seriam concedidos caso a mesma lesão tivesse sido causada a um recém-nascido, pois não é reconhecida ainda a personalidade jurídica do nascituro, uma vez que os julgadores se atentam à letra isolada do artigo $2^{\circ}$ do Código Civil, ao invés de enxergar o sistema jurídico como um todo. 
Conclui-se o presente estudo no sentido de que o reconhecimento da qualidade de pessoa do nascituro se faz premente no meio jurídico. Pensar de outra maneira seria caminhar em sentido contrário ao da evolução do pensamento jurídico humanista, retrocedendo a épocas sombrias em que não se respeitavam todos os seres humanos igualmente, nem lhes era reconhecida qualquer dignidade. Nesta época, valorizava-se mais o "ter” do que o “ser”. Manter aquele pensamento seria como voltar a um tempo em que o ser humano não era o centro das relações jurídicas, mas sim seu patrimônio ou sua potência. 


\section{REFERÊNCIAS BIBLIOGRÁFICAS}

ALBALADEJO, Manuel. Derecho Civil I: introducción y parte general. v. 1 - Introducción y Derecho de la Persona. 4. ed. Barcelona: Bosch, 1975.

ALVES, Moreira. Direito Romano. 14. ed. Rio de Janeiro: Forense, 2007.

ALVIM, Agostinho. Da inexecução das obrigações e suas consequências. 5. ed. São Paulo: Saraiva, 1980.

AMARAL. Francisco. Direito Civil: Introdução. 3. ed. Rio de Janeiro/São Paulo: Renovar, 2000. . Direito Civil. Introdução. 6. ed. Rio de Janeiro: Renovar, 2006.

AMARAL NETO, Francisco dos Santos. O nascituro no Direito Civil Brasileiro. Contribuição do Direito Português. Revista Brasileira de Direito Comparado, Rio de Janeiro, Forense, v. 8, p. 7590, 1990.

AZEVEDO, Antonio Junqueira de. Caracterização jurídica da dignidade da pessoa humana. Revista Trimestral de Direito Civil, v. 9, jan./mar. 2002.

. O Direito Pós-Moderno e a Codificação. Revista de Direito do Consumidor, São Paulo: Revista dos Tribunais, n. 33, p. 123-129, jan./mar.2000.

BARROSO, Luís Roberto. Interpretação e Aplicação da Constituição: fundamentos de uma dogmática constitucional transformadora. 6. ed. São Paulo: Saraiva, 2008.

BEVILAQUA, Clóvis. Código Civil Comentado. v. 6. 6. ed. Rio de Janeiro: Francisco Alves, 1947.

1976.

. Código Civil dos Estados Unidos do Brasil Comentado. 2a tiragem. Rio de Janeiro: Rio,

. Teoria Geral do Direito Civil. Servanda: Campinas, 2007.

BITTAR, Carlos Alberto. Dano Moral: Critérios para a sua fixação. Boletim IOB, n. 15/93, p. 291-293, ago. 1993.

. Danos patrimoniais e morais por violações a direitos da personalidade. Revista do Advogado, São Paulo, n. 38, dez. 1992.

. Direitos da Personalidade. 6. ed. atual. Rio de Janeiro: Forense, 2003.

. Reparação Civil por danos morais, 2. ed. São Paulo: Revista dos Tribunais, 1994. 
BOBBIO, Norberto. A Era dos Direitos. Rio de Janeiro: Elsevier, 2004.

BOFF, Leonardo. A Ética da Vida. Rio de Janeiro: Sextante, 2005.

BONAVIDES, Paulo. Curso de Direito Constitucional. 13. ed. São Paulo: Malheiros, 2003.

BORGES, Roxana Cardoso Brasileiro. Direitos de personalidade e dignidade: da responsabilidade civil para responsabilidade constitucional. In: DELGADO, Mário Luiz; ALVES, Jones Figueirêdo (Coord.). Questões Controvertidas no Novo Código Civil. v. 5. São Paulo: Método, 2006. p. 557-582.

BRASIL. Lei federal n. 8.069 de 13 de julho de 1990. Dispõe sobre o Estatuto da Criança e do Adolescente e dá outras providências. D.O.U. 16.7.1990.

BRASIL. Lei federal n. 8.078 de 11 de setembro de 1990. Dispõe sobre a proteção do consumidor e dá outras providências. D.O.U. 12.09.1990.

BRASIL. Lei federal n. 11.105, de 24 de março de 2005. Regulamenta os incisos II, IV e V do $\S$ $1^{0}$ do art. 225 da Constituição Federal, estabelece normas de segurança e mecanismos de fiscalização de atividades que envolvam organismos geneticamente modificados - OGM e seus derivados, cria o Conselho Nacional de Biossegurança - CNBS, reestrutura a Comissão Técnica Nacional de Biossegurança - CTNBio, dispõe sobre a Política Nacional de Biossegurança - PNB, revoga a Lei $\mathrm{n}^{0}$ 8.974, de 5 de janeiro de 1995, e a Medida Provisória $\mathrm{n}^{\mathbf{0}}$ 2.191-9, de 23 de agosto de 2001 , e os arts. $5^{\circ}, 6^{-0}, 7^{0}, 8^{0}, 9^{-0}, 10$ e 16 da Lei $n^{0} 10.814$, de 15 de dezembro de 2003, e dá outras providências. D.O.U. 28.03.2005.

BRASIL. Lei federal n. 11.804 de 5 de novembro de 2008. Disciplina o direito a alimentos gravídicos e a forma como ele será exercido e dá outras providências. D.O.U. 06.11.2008.

CAHALI, Yussef Said. Dano Moral. 2. ed. São Paulo: Revista dos Tribunais, 1999.

CAMPOS, Diogo Leite de. A capacidade sucessória do nascituro (ou a crise do positivismo legalista). In: CAMPOS, Diogo de Leite; CHINELLATO, Silmara Juny de Abreu (Coord.). Pessoa Humana e Direito Coimbra: Almedina, 2009.

CAPELO DE SOUSA, Rabindranath Valentino Aleixo. O direito geral de personalidade. Coimbra: Coimbra Editora, 1995.

CARVALHO SANTOS, João Manuel de. Código Civil Brasileiro Interpretado, principalmente do ponto de vista prático. v. 1. 15. ed. Rio de Janeiro: Freitas Bastos, 1992.

CATALANO, Pierangelo. Os nascituros entre o Direito Romano e o direito latino-americano. Trad. Eduardo César Vita Marchi. Revista de Direito Civil, n. 45, ano 12, p. 07-15, jul./set. 1998.

CHINELLATO, Silmara Juny de Abreu. Tutela Civil do Nascituro. São Paulo: Saraiva, 2002. 
CHINELLATO, Silmara Juny de Abreu. Adoção de nascituro e a quarta era dos direitos: razões para se alterar o caput do artigo 1.621 do Novo Código Civil. In: DELGADO, Mário Luiz; ALVES, Jones Figueirêdo (Coord.). Questões Controvertidas no Novo Código Civil. v. 1. São Paulo: Método, 2003. p. 355-372.

. Bioética e dano pré-natal. In: FERRARI, Paulo Leme (Coord.). Direito de família. Homenagem a Sérgio Marques da Cruz. Revista do Advogado, São Paulo: Associação dos Advogados de São Paulo, n. 58, p. 62-77, mar. 2000.

Direito do nascituro a alimentos - uma contribuição do Direito Romano. Revista de Direito Civil, Imobiliário, Agrário e Empresarial, São Paulo, n.54, p. 52-61, out./dez. 1990. dez. 1992.

Direitos da personalidade do nascituro. Revista do Advogado. São Paulo: n. 38, p. 21-30,

. Estatuto Jurídico do Nascituro: O Direito Brasileiro. In: DELGADO, Mário Luiz; ALVES, Jones Figueirêdo (Coord.). Questões Controvertidas no Novo Código Civil. v. 6. São Paulo: Método, 2007. p. 43-104.

O nascituro perante os Tribunais: A recente decisão do Tribunal de Justiça de São Paulo. Revista do Advogado, São Paulo, n. 20, p. 222-230, jul./dez. 2007.

. O nascituro no Código Civil e no Direito Constituendo do Brasil. Revista de Direito Civil, Imobiliário, Agrário e Empresarial, São Paulo, n.44, p. 180-7, abr./jun. 1988.

Tendências da responsabilidade civil no direito contemporâneo: reflexos no Código de 2002. In: DELGADO, Mário Luiz; ALVES, Jones Figueirêdo (Coord.). Questões Controvertidas no Novo Código Civil. v. 5. São Paulo: Método, 2006. p. 583-606.

CHORÃO, Mário Bigotte. Pessoa Humana, direito e política. Lisboa: Imprensa Nacional - Casa da Moeda, 2006.

CÓDIGO CIVIL DE LA REPÚBLICA ARGENTINA. Disponível em: <www.redetel.gov.ar/Normativa/Archivos\%20de\%20Normas/CodigoCivil.htm>. Acesso em: 10 nov. 2009.

COELHO, Fábio Ulhoa. Curso de Direito Civil. v. 1. São Paulo: Saraiva, 2003.

COMPARATO, Fábio Konder. A afirmação histórica dos direitos humanos. 4. ed. São Paulo: Saraiva, 2006.

CONSELHO DA EUROPA. Disponível em : <www.coe.int>. Acesso em: 10 nov. 2009.

CONSELHO DA JUSTIÇA FEDERAL. Disponível em : <www.cjf.jus.br>. Acesso em: 10 nov. 2009. 
CONSULTOR JURÍDICO. Disponível em : <www.conjur.com.br>. Acesso em: 01 dez. 2009

CORTE CONSTITUZIONALE DELLA REPUBBLICA ITALIANA. Disponível em: <www.cortecostituzionale.it>. Acesso em: 10 nov. 2009.

CORRÊA, Aparecida de Andrade; GIACOIA, Gilberto; CONRADO, Marcelo (Coord.). Biodireito e Dignidade da Pessoa Humana. Curitiba: Juruá, 2007.

COUR DE CASSATION. Disponível em : <www.courdecassation.fr>. Acesso em: 11 out. 2009.

CRETELLA JÚNIOR. José. Curso de Direito Romano: o direito romano e o direito civil brasileiro. 24. ed. rev. e aum. Rio de Janeiro: Forense, 2000.

DE MATTIA, Fábio. Direitos da personalidade: aspectos gerais. Revista de Direito Civil v. 2, n. 3, p. 35-51, jan./mar. 1978.

DIAS, José de Aguiar. Da Responsabilidade Civil. 11. ed. Renovar: Rio de Janeiro, 2006.

DINIZ, Maria Helena. Curso de Direito Civil Brasileiro. v. 1 - Teoria Geral do Direito civil. 23. ed. São Paulo: Saraiva, 2006.

. Curso de Direito Civil Brasileiro: responsabilidade civil. v. 7. São Paulo: Saraiva, 2008.

DIREITO 2. Disponível em : <www.direito2.com.br/tjmg/2007/ago/28/justica-garante-direitosde-nascituro>. Acesso em: 10 nov. 2009.

FERREIRA, Aurélio Buarque de Holanda. Novo Aurélio Século XXI: o dicionário da língua portuguesa. 3. ed. Rio de Janeiro: Nova Fronteira, 1999.

FIUZA, César. Direito Civil: curso completo. 8. ed. Belo Horizonte: Del Rey, 2004.

FIUZA, Ricardo (Coord.). Novo Código Civil Comentado. 4. ed. atual. São Paulo: Saraiva, 2005.

GARCIA, Maria. Limites da Ciência: A dignidade da pessoa humana, a ética da responsabilidade. São Paulo: RT, 2004.

GAZZONI, Francesco. Manuale di Diritto Privato, Napoli: Edizioni Scientifiche Italiane, 1994.

GOMES, Orlando. Direitos da Personalidade. Revista Forense, Rio de Janeiro, v. 216, p. 5-10, out./dez. 1966.

Introdução ao Direito Civil. 19. ed. rev., atual. e aum. Rio de Janeiro: Forense, 2008.

. Obrigações. Rio de Janeiro: Forense, 1961.

. Obrigações. 12. ed. Rio de Janeiro: Forense, 1998. 
GONÇALVES, Carlos Roberto. Direito Civil Brasileiro. v. 4. 2. ed. São Paulo: Saraiva, 2007.

GONÇALVES, Carlos Roberto. Direito Civil Brasileiro: Responsabilidade Civil. v. 5. 2. ed. São Paulo: Saraiva, 2007.

HIRONAKA, Giselda Maria F. Novaes. Responsabilidade pressuposta. Belo Horizonte: Del Rey, 2005.

. Responsabilidade pressuposta. Evolução de fundamentos e de paradigmas da responsabilidade civil na contemporaneidade. In: DELGADO, Mário Luiz; ALVES, Jones Figueirêdo (Coord.). Questões Controvertidas no Novo Código Civil. v. 5 - Responsabilidade civil. São Paulo: Método, 2006. p. 197-222.

IUDICA, Giovanni e ZATTI, Paolo. Linguaggio e regole Del Diritto Privato. 6. ed. Padova: Cedam, 2005.

LÉGIFRANCE, SERVICE PUBLIC DE LA DIFFUSION DU DROIT PAR L'INTERNET. Disponível em : <www.legifrance.gouv.fr>. Acesso em : 10 nov. 2009.

LEITE, Eduardo Oliveira. Procriações Artificiais e o Direito: aspectos médicos, religiosos, psicológicos, éticos e jurídicos. São Paulo: Revista dos Tribunais, 1995.

O direito do embrião humano: mito ou realidade? Revista de Direito Civil, ano 20, v. 78, p. 23-40, out./dez. 1996.

LIMA, Alvino. Culpa e Risco. São Paulo: RT, 1998.

LIMA, Pires de; VARELA, Antunes. Código Civil Anotado. v. 1 - $\operatorname{artigos} 1^{\circ}$ a 761.4 . ed. Coimbra: Coimbra Editora, 1987.

LIMONGI FRANÇA, Rubens. Instituições do Direito Civil. 5. ed. ver. atual. São Paulo: Saraiva, 1999.

. Manual de Direito Civil I. 4. ed. São Paulo: Revista dos Tribunais, 1980.

. Direitos da Personalidade: Coordenadas fundamentais. Revista dos Tribunais, São Paulo, v. 567, p. 9-16, jan./mar. 1983.

MACIEL, Hélcio. O nascituro no direito romano: conceito, terminologia e princípios in Coleção Cadernos FAENAC. São Paulo: Companhia Editora Nacional, 2005.

MARKY, Thomas. Curso Elementar de Direito Romano. 8. ed. São Paulo: Saraiva, 1995.

MELLO, Celso A. B. Conteúdo Jurídico do Princípio da Igualdade. 3. ed. São Paulo: Malheiros, 2009. 
MENDES, Gilmar Ferreira; COELHO, Inocêncio Mártires; BRANCO, Paulo Gustavo Gonet. Curso de Direito Constitucional. 4. ed. ver. e atual. São Paulo: Saraiva, 2009.

MONTEIRO, Antônio Pinto. Direito a não nascer? Revista do IASP, ano 10, n. 19, p. 321-331, jan./jun. 2007.

MONTEIRO, Fernando Pinto. Direito à não existência, direito a não nascer. In: Comemoração dos 35 anos do Código Civil e dos 25 anos da reforma de 1977. v. 2 - A Parte Geral do Código e a Teoria Geral do Direito Civil. Coimbra: Coimbra Editora, 2006.

MONTEIRO, Washington de Barros. Curso de Direito Civil. v. 1. 37. ed. rev. e atual. por Ana Cristina de Barros Monteiro França Pinto. São Paulo: Saraiva, 2000.

MONTORO, André Franco; FARIA, Anacleto de Oliveira. Condição Jurídica do Nascituro no Direito Brasileiro. São Paulo: Saraiva, 1953.

MORAES, Maria Celina Bodin de. A Caminho de um Direito Civil Constitucional. Revista de Direito Civil, v. 17, n.65, p.21-32, jul./set. 1993.

MORAES, Walter. O problema da autorização judicial para o aborto. Revista de Jurisprudência do Tribunal de Justiça do Estado de São Paulo, v. 99, ano 20, p. 24-25, mar./abr. 1986.

MOREIRA, José Carlos Barbosa. O Direito do Nascituro. Revista Brasileira de Direito de Família, ano VII, n. 34, fev./mar. 2006.

MOREIRA ALVES, José Carlos. Direito Romano. 14. ed., Rio de Janeiro: Forense, 2007.

MOTA PINTO, Carlos Alberto da. Teoria Geral do Direito Civil. 3. ed. Coimbra: Coimbra Editora, 1999.

NADER, Paulo. Curso de Direito Civil: parte geral. v. 1. 4. ed. rev. e atual.. Rio de Janeiro: Forense, 2007.

NERY JÚNIOR, Nelson; NERY, Rosa Maria de Andrade. Código Civil Comentado. 6. ed. rev., ampl. e atual. São Paulo: RT, 2008.

NORBIM, Luciano Dalvi. O direito do nascituro à personalidade civil. Brasília: Brasília Jurídica, 2006.

NORONHA, Fernando. Desenvolvimentos Contemporâneos da Responsabilidade Civil. Revista dos Tribunais, São Paulo, ano 88, v. 761, mar. 1999.

OLIVEIRA, Euclides Benedito de. Nascituro, esse desconhecido. Direito à indenização por danos materiais e morais. Direito de família e Ciências Humanas, Caderno de Estudos, n. 2, coord. Eliana Riberti Nazareth e Maria Antonieta Pisano Motta, Instituto de Estudos Interdisciplinares de Direito de Família, São Paulo, Ed. Jurídica Brasileira, p. 77-90. 
OLIVEIRA, Euclides Benedito de. Indenização por danos morais ao nascituro. In: DINIZ, Maria Helena; LISBOA, Roberto Senise (Coord.). O Direito Civil no século XXI. São Paulo: Saraiva, 2003.

PARLAMENTO ITALIANO. Disponível em: <www.parlamento.it/leggi/elelenum.htm>. Acesso em: 10 nov. 2009.

PEREIRA, Caio Mário da Silva. Instituições de Direito Civil. v. 1. 19. ed. Rio de Janeiro: Forense, 2001.

. Instituições de Direito Civil. v. 3. 13. ed. Rio de Janeiro: Forense, 2009.

. Responsabilidade Civil. Rio de Janeiro: Forense, 1999.

PERLINGIERI, Pietro. Códice Civile Anotato com la dottrina e la giurisprudenza: Libro Primo: Delle persone e della famiglia. Napoli: Edizioni Scientifiche Italiane, 1991.

PIOVESAN, Flávia. Direitos Humanos e o Direito Constitucional Internacional. São Paulo: Saraiva, 2007.

. Temas de Direitos Humanos. 3. ed. São Paulo: Saraiva, 2009.

PONTES DE MIRANDA, Francisco Cavalcanti. Tratado de Direito Privado. Tomo I. Campinas: Bookseller, 2000.

PORCHAT, Reinaldo. Da pessoa physica em Direito Romano: sua condição natural, o nascimento perfeito; sua condição civil, o status, Revista da Faculdade de Direito de São Paulo, ano 1991, v. 19, 1913.

PUSSI, Artur William. Personalidade Jurídica do Nascituro. Curitiba: Juruá, 2006.

RÁO, Vicente. O Direito e a vida dos direitos. 5. ed. anot. e atual.. São Paulo: Revista dos Tribunais, 1999.

REALE, Miguel. Temas de Direito Positivo. São Paulo: Revista dos Tribunais, 1992.

REZEK, Francisco. Direito Internacional Público: curso elementar. 11. ed. rev. e atual. São Paulo: Saraiva, 2008.

RIZZARDO, Arnaldo. Direito de Família. v. 1. Rio de Janeiro: Aide, 1994.

. Parte Geral do Código Civil. 5. ed. Rio de Janeiro: Forense, 2007.

RODRIGUES, Rafael Garcia. A pessoa e o ser humano no Código Civil. In: TEPEDINO, Gustavo (Coord.). A parte Geral do Novo Código Civil: estudos na perspectiva CivilConstitucional. Rio de Janeiro: Renovar, 2007. 
RODRIGUES, Silvio. Direito Civil: parte geral. v. 1. 34 ed. São Paulo: Saraiva, 2003.

SANTOS, Maria Celeste Cordeiro Leite (Org.). Biodireito: ciência da vida, os novos desafios. São Paulo: RT, 2001.

SANTOS, Antonio Jeová. Dano moral indenizável. São Paulo: Método, 2001.

SARAIVA, Gastão Grossé. Os direitos do nascituro e o art. $4^{\circ}$ do Código Civil. Revista dos Tribunais, v. 131, p. 444-455, maio/jul. 1941.

SEGRE, Marco. Bioética. São Paulo: EDUSP, 2002.

SERPA LOPES, Miguel Maria de. Curso de Direito Civil. v. 1. Introdução, Parte Geral e Teoria dos Negócios Jurídicos. 7. ed. ver. e atual. Rio de Janeiro: Freitas Bastos, 1989.

SEVERINO, Emanuele. Sull'embrione. Milano: Rizzoli, 2005.

SILVA, Rafael Peteffi da. Responsabilidade Civil pela perda de uma chance: comparação jurídica e direito positivo para um modelo dogmático brasileiro, 2004. Tese de Doutorado em Direito pela Universidade de São Paulo.

STOCO, Rui. Responsabilidade Civil e sua Interpretação Jurisprudencial. 4. ed. São Paulo: Revista dos Tribunais, 1999.

SUPREMO TRIBUNAL DE JUSTIÇA DE PORTUGAL. Disponível em: <www.stj.pt>. Acesso em: 11 out. 2009.

SUPREMO TRIBUNAL FEDERAL. Disponível em: <www.stf.jus.br>. Acesso em: 10 dez. 2009.

TARTUCE, Flávio. A situação jurídica do nascituro: uma página a ser virada no direito brasileiro. In: DELGADO, Mário Luiz; ALVES, Jones Figueirêdo (Coord.). Questões Controvertidas no Novo Código Civil. v. 6. São Paulo: Método, 2007.

TAVARES, José. Os princípios fundamentais do Direito Civil. v. 2. Coimbra: Coimbra Editora, 1928.

TEIXEIRA DE FREITAS, Augusto. Esboço do Código Civil. Brasília, Ministério da Justiça, Fundação Universidade de Brasília, 1983.

TEMER, Michel. Elementos de direito constitucional. 22. ed. São Paulo: Malheiros, 2008.

THEODORO JÚNIOR, Humberto. Curso de Direito Processual Civil. Rio de Janeiro: Forense, 2006.

Dano Moral. 3. ed. São Paulo: Revista dos Tribunais, 2005. 
TRIBUNAL DE JUSTIÇA DO ESTADO DE GOIÁS. Disponível em: <www.tjgo.jus.br>. Acesso em: 10 nov. 2009.

VENOSA, Sílvio de Salvo. Direito Civil: parte geral. v. 1. 6. ed. São Paulo: Atlas, 2006. . Direito Civil. Responsabilidade Civil. 5. ed. São Paulo: Atlas, 2005.

VILLAÇA AZEVEDO, Álvaro. Teoria geral das obrigações: responsabilidade civil. Curso de direito civil. 10. ed. São Paulo: Atlas, 2004.

- Nascituro é pessoa. Breves noções. In: Roma, Università di Roma - La Sapienza/Consiglio Nazionale delle Ricerche, 1997, p. 1-7.

VILLELA, João Baptista. Para além do lucro e do dano: efeitos sociais benéficos do risco. Repertório IOB de Jurisprudência. São Paulo, n. 22/91, cad. 3, nov. 1991.

VOCI, Pasquale. Manuale di Diritto Romano. v. 2. Milano: Giuffrè, 1998. 